\title{
Basement membrane heterogeneity
}

Citation for published version (APA):

Cleutjens, J. P. M. (1989). Basement membrane heterogeneity. [Doctoral Thesis, Maastricht University]. Rijksuniversiteit Limburg. https://doi.org/10.26481/dis.19890608jc

Document status and date:

Published: 01/01/1989

DOI:

10.26481/dis.19890608jc

Document Version:

Publisher's PDF, also known as Version of record

\section{Please check the document version of this publication:}

- A submitted manuscript is the version of the article upon submission and before peer-review. There can be important differences between the submitted version and the official published version of record.

People interested in the research are advised to contact the author for the final version of the publication, or visit the DOI to the publisher's website.

- The final author version and the galley proof are versions of the publication after peer review.

- The final published version features the final layout of the paper including the volume, issue and page numbers.

Link to publication

\footnotetext{
General rights rights.

- You may freely distribute the URL identifying the publication in the public portal. please follow below link for the End User Agreement:

www.umlib.nl/taverne-license

Take down policy

If you believe that this document breaches copyright please contact us at:

repository@maastrichtuniversity.nl

providing details and we will investigate your claim.
}

Copyright and moral rights for the publications made accessible in the public portal are retained by the authors and/or other copyright owners and it is a condition of accessing publications that users recognise and abide by the legal requirements associated with these

- Users may download and print one copy of any publication from the public portal for the purpose of private study or research.

- You may not further distribute the material or use it for any profit-making activity or commercial gain

If the publication is distributed under the terms of Article $25 \mathrm{fa}$ of the Dutch Copyright Act, indicated by the "Taverne" license above, 
Het verschijnen van dit proefschrift werd financieel ondersteund door de Stichting Bevordering KIinische Pathologie Limburg en de Stichting het Scholten Cordes Fonds. 


\section{BASEMENT MEMBRANE HETEROGENEITY}





\title{
BASEMENT MEMBRANE HETEROGENEITY
}

\author{
PROEFSCHRIFT
}

ter verkrijging van de graad van doctor

aan de Rijksuniversiteit Limburg te Maastricht, op gezag van de Rector Magnificus, prof.dr. F.I.M. Bonke, volgens het besluit van het College van Dekanen,

in het openbaar te verdedigen op donderdag, 8 juni 1989 om 16.00 urur

door

Jacobus Peter Marie Cleutjens

geboren te Oirsbeek in 1958 
promotor:

prof.dr. F.T. Bosman

beoordelingscommissie: prof.dr. P.J.C. wan Breda Vriesman (voorzitter)

prof.dr. I Damjanow

prof.dr. J. Drukker

prof.dr. J.P.M. Greraedts

prof..dr. Ph. J. Hoedemaeker

This project was financially supported by the Netherlands Cancer Foundation "Het Koningin Wilhelmina Fonds", grant RUL 85-2. 


\section{Confetti}

Confetti is alleen dàn confetti als hij (of zij?) meerkleurig is.

Het strooien van énkleurige confetti sorteert vrijwel geen effect,

't is de mengeling die het ' $m$ doet -c'est la vie!

Toon Hermans

Ik heb het leven lief (1981) 



\section{Contents}

List of abbreviations

$\begin{array}{lll}\text { Chapter } 1 & \text { General introduction } & 13\end{array}$

1.1 Introduction 14

1.2 BM biosynthesis and turnover $\quad 14$

1.3 General structure of the BM 15

1.3.1 Morphology 15

1.3.2 Chemical composition 16

1.3.2.1 Components of all BM 16

$\begin{array}{ll}\text { Type IV collagen } & 16\end{array}$

Laminin 18

Heparan sulphate proteoglycan $\quad 18$

Entactin/nidogen 18

LDA-1 19

1.3.2.2 Components with a limited tissue distribution 19

Anchoring fibers 19

Chondroitin sulphate proteoglycan 19

Type V collagen 19

Fibronectin 20

1.3.3 BM heterogeneity $\quad 20$

1.3.3.1 Normal variations $\quad 20$

Morphology 20

Composition 21

$\begin{array}{ll}\text { 1.3.3.2 Pathologic wariation } & 21\end{array}$

Morphology 21

Composition $\quad 22$

Goodpasture syndrome $\quad 23$

Bullous pemphigoid 23

Cicatricial pemphigoid $\quad 23$

Epidermolysis bullosa $\quad 23$

1.4 Aim of the study 24

1.5 References 25

Chapter 2 Monoclonal antibodies to native basement membranes reveal heterogeneous immunoreactivity patterns $\quad 33$

2.1 Introduction 34

2.2 Materials and methods $\quad 34$

2.2.1 Immunogens $\quad 34$

2.2.2 Immunization and monoclonal antibody production 35

2.2.3 Antibodies 35

2.2.4 Tissues $\quad 35$

2.2.5 Digestion of frozen sections 35 
2.2.6 Chemical cleavage of the epidermal basement membrane 36

2.3 Results 36

2.3.1 Hybridomas obtained 36

2.3.2 Reactivity on human tissues 36

2.3.3 Chemical cleavage of the epidermal BM 39

2.3.4 Digestion of frozen sections $\quad 41$

2.4 Discussion 41

2.5 References 43

Chapter 3 Biochemical and immunohistochemical characterization of monoclonal antibodies against the $\mathrm{NC1}$ globular domain of type IV collagen

3.1 Introduction 46

3.2 Materials and methods $\quad 47$

3.2.1 Isolation of the basement membranes 47

3.2.2 Monoclonal antibodies $\quad 47$

3.2.3 Immunohistochemistry 47

3.2.4 Pretreatment of tissue sections 48

3.2.5 Patients and sera 48

3.2.6 Collagenase digestion 48

3.2.7 Electrophoresis 49

3.3 Results 49

3.3.1 Immunohistochemistry 49

3.3.2 Immunochemistry 50

3.4 Discussion 53

3.5 References 54

Chapter 4 Absence of type IV collagen in corneal epithelial basement membrane $\quad 57$

$\begin{array}{lll}4.1 & \text { Introduction } & 58\end{array}$

4.2 Materials and methods $\quad 58$

4.2.1 Antibodies $\quad 58$

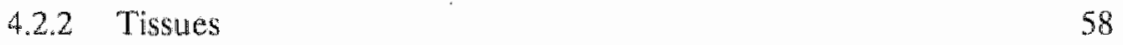

4.2 .3 Immunohistochemistry $\quad 59$

4.2.4 Tissue pretreatment $\quad 59$

4.2.5 Electron microscopy $\quad 59$

4.3 Results $\quad 59$

4.4 Discussion 63

4.5 References 65

Chapter 5 Umbilical cord stromal cells are myofibroblasts: isolation, immunohistochemical and ultrastructural characterization 67

$\begin{array}{lll}5.1 & \text { Introduction } & 68\end{array}$

$\begin{array}{ll}5.2 & \text { Materials and methods } \\ 5.2 . & 68\end{array}$

5.2.1 Antibodies 68 
5.2.2 Tissue culture $\quad 69$

5.2.3 Electron microscopy 69

$\begin{array}{lll}5.2 .4 & \text { Immunohistochemistry } & 69\end{array}$

5.2.5 Electrophoresis and western blotting 69

$\begin{array}{lll}5.26 & \text { Immunoaffinity purification } & 70\end{array}$

5.2 .7 Northern blatting 70

5.2.8 In situ hybridization 70

5.3 Results 71

5.3.1 Cell morphology 71

$\begin{array}{ll}\text { 5.3.2 Immunophenotype } & 74\end{array}$

5.3.3 Production of BM components 75

$\begin{array}{lll}5.4 & \text { Discussion } & 76\end{array}$

$\begin{array}{lll}5.5 & \text { References } & 77\end{array}$

Chapter 6 Origin of basement membrane type IV collagen in xenografted $\begin{array}{ll}\text { human epithelial tumor cell-lines } & 79\end{array}$

6.1 Introduction 80

6.2 Materials and methods $\quad 80$

6.2 .1 Tissues $\quad 80$

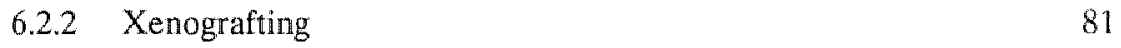

6.2.3 Antibodies 81

6.2.4 Immunoblotting of culture supernatants 82

6.2 .5 Immunohistochemistry 82

6.2.6 In situ hybridization $\quad \$ 2$

6.3 Results 8.3

6.3.1 Antibody specificity $\$ 8.3$

6.3.2 Type IV collagen detection in cancer cell lines 84

6.3.3 Type IV collagen detection in xenografts 87

6.3.4 In situ hybridization $\quad 89$

6.4 Discussion 90

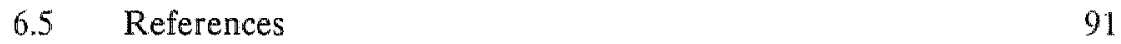

Chapter 7 In vitro production and deposition of basement membrane components

7.1 Introduction 96

7.2 Materials and methods 96

7.2.1 Cell lines 96

7.2.2 Tissue culture 97

7.2.3 Isolation of denuded amniotic membranes 97

7.2 .4 Xenografting 98

7.2.5 Dot- and immunoblotting 08

7.2 .6 Northern blotting 988

7.2.7 In situ hybridization 98

7.2.8 Immunohistochemistry 09

7.2.9 Electron microscopy 99 
7.3 Results 99

7.4 Discussion 103

$\begin{array}{ll}7.5 \text { References } & 104\end{array}$

$\begin{array}{lll}\text { Chapter 8 } & \text { General discussion } & 107\end{array}$

8.1 Introduction 108

8.2 New BM components? 108

8.3 Do all BM have a uniform structure and morphology? 109

8.4 How is the epithelial BM deposited? 110

8.5 Future perspective 111

8.6 References 1 II

Chapter $9 \quad$ Addendum 113

9.1 Immunization and monoclonal antibody production 114

9.1.1 Immunization with amniotic BM 114

9.1.2 Immunization with glomerular BM 114

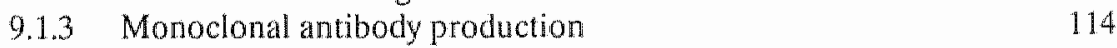

$\begin{array}{lll}9.2 & \text { Immunohistochemistry } & 114\end{array}$

9.3 Tissue pretreatment 115

9.4 Antibodies 115

9.5 Electrophoresis and Western blotting 115

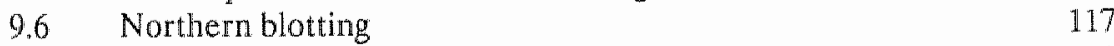

9.7 In situ hybridization $\quad 118$

9.8 Type I collagen lattices 118

9.8.1 Isolation of human type I collagen 118

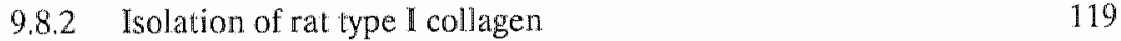

9.8.3 Preparation of type I collagen lattices $\quad 119$

9.9 References 119

Summary

$\begin{array}{ll}\text { Samenvatting } & 125\end{array}$

$\begin{array}{ll}\text { Dankwoord } & 129\end{array}$

$\begin{array}{ll}\text { Curriculum vitae } & 131\end{array}$ 


\section{List of abbreviations}

$\begin{array}{ll}\text { BAPN } & \text { B-amino-propionitrile fumarate } \\ \text { BM } & \text { Basement membrane(s) } \\ \text { BSA } & \text { Bovine serum albumin } \\ \text { ECM } & \text { Extracellular matrix } \\ \text { EHS } & \text { Engelbreth-Holm-Swarm tumor } \\ \text { ELISA } & \text { Enzyme linked immunosorbent assay } \\ \text { FCS } & \text { Fetal calf senm } \\ \text { GBM } & \text { Glomerular basement membrane } \\ \text { HSPG } & \text { Heparan sulphate proteoglycan } \\ \text { kD } & \text { KiloDalton } \\ \text { MA } & \text { monoclonal antibod(y)ies } \\ \text { Mw } & \text { Molecular weight } \\ \text { NC1 } & \text { non-collagenous domain 1 of type IV collagen } \\ \text { NEM } & \text { N-ethylmaleïmide } \\ \text { PA } & \text { polyclonal antiser(um)a } \\ \text { PBS } & \text { Phosphate buffered saline } \\ \text { PEG } & \text { Polyethylene glycol } \\ \text { Pen } & \text { Penicillin } \\ \text { RIA } & \text { Radioimmunoassay } \\ \text { RT } & \text { Room temperature } \\ \text { Strep } & \text { Streptomycin }\end{array}$





\section{Chapter 1}

General introduction 


\section{1 introduction}

The basement membrane (BM) is a special component of the extracellular matrix (ECM), which is deposited as a sheet-like structure in close vicinity to the adherent cell. The BM may be deposited in a polarized fashion at the basal side of some cells (epithelial and endothelial cells) or may completely surround individual cells such as adipocytes, myocytes, and Schwann cells (1). Several important biological functions are ascribed to BM. They are responsible for tissue compartmentalization in maintaining tissue architecture. They provide adequate anchorage for adjacent cells, which thus maintain their polarized and differentiated state. They control cell migration and invasion and they can act as selective filtration barriers, as in the capillaries of the renal glomerulus (2-5).

\section{$1.2 \mathrm{BM}$ biosynthesis and turnover}

The extracellular matrix, including the BM was regarded until recently as a passive and inert structural framework for the epithelial and mesenchymal cellular components of a tissue (6). Fully assembled BM are indeed relatively stable. Turnover rates from 40 days in the collon to more than 2 years in skin were estimated on the basis of the rate of silver stain loss (7). In vivo labeling of glomerular BM with anti-laminin antibodies showed that the antibodies remained bound for several months (8). Metabolic labeling with radioacive amino acids showed that collagenous components have a slower turnover rate than noncollagenous components (9). Faster turnover rates have been found during morphogenesis, as in tooth development, and pathological conditions, such as neoplasid.

It is generally assumed that epithelial BM are at least partly produced and deposited by the epithelial cells $(10,11)$. In vitro, epithelial cells are usually capable to produce BM components and secrete these into the culture medium (12-15).

Mesenchymal cells such as Schwann cells, muscle cells and fat cells are also capable of BM production (2). These cells produce and deposit the extracellular matrix components into a normal BM in vivo. In vitro, Schwann cells (16) and muscle cells (17) have been shown to produce and deposit BM-like structures. Evidence exists that mesenchymal cells contribute to the BM formation. Cocultivation of mouse muscle fibroblasts and quail skeletal myoblasts results in deposition of a BM of mouse origin $(18,19)$, and combination of chick mesenchyme and rat endoderm results in the formation of a BM of chick origin (20). Xenotransplantation of human tumor cells into athymic animals resulted in the formation of BM-like structures with components of both host and tumor cell origin $(21,22)$. These results indicate that BM are deposited as a result of cellular interactions: between epithe lial and mesenchymal cells for epithelial BM and between different mesenchymal cells for mesenchymal BM (myocytes, adipocytes, Schwann cells and endothelial cells). 


\subsection{General structure of the BM}

\subsubsection{Morphology}

Electron microscopically most BM appear as a three layered structure $(2,5,23)$ as illustrated in Fig 1. The lamina lucida, also called lamina rara, is an electron lucent layer ad. jacent to the plasma membrane of the adherent cell. In the lamina lucida very delicate anchoring filaments occur, which traverse this layer perpendicular to the plasma membrane (24). The lamina densa is an electron dense layer, situated at the stromal side of the lamina lucida, and at high magnification appears as a network of cords (25). Findly, underlying the lamina densa the subbasal lamina or lamina fubroneticularis occurs, which contains fibrils anchoring the BM onto the underlying stroma. These consist of anchoring fibrils, elastic microfibrils and fine interstitial fibrils, which probably represent reticulin (25). Epithelial cells are attached to the BM by hemidesmosomes.

The hemidesmosomes contain an intracellular attachment plaque, which is in contact with the plasma membrane, intracytoplasmic actin and keratin tonofilaments, and an extracellular subbasal dense plate located in the BM.

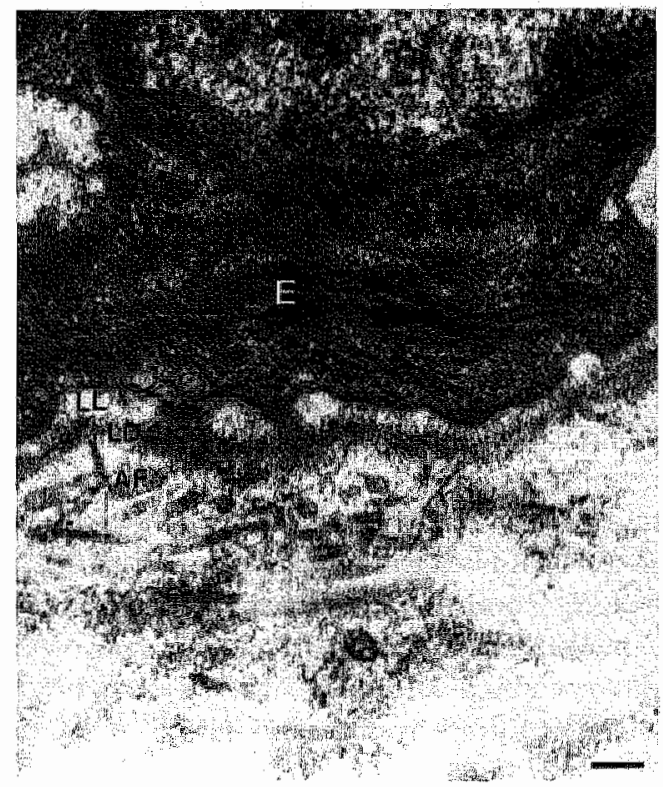

Figure 1. Electronmicrograph of peripheral (conjunctival) human corneal epithelial basement membrane. E: $=$ epithelium; $\mathrm{LL}=$ lamina lucida; $\mathrm{LD}=$ lamina densa; $\mathrm{AF}=$ anchoring fibcrs. Scale bar $=0.1$ u.m. 
Anchoring filaments are more numerous in the hemidesmosomal region than in the region between hemidesmosomes. Evidence exists that anchoring fibrils occur predominantly at the hemidesmosomal sites (25-27). Consequently the anchoring of epithelial cells is mediated by a complex network of intracytoplasmic filaments, hemidesmosomes, BM components and anchoring fibrils. Another mechanism of cell-matrix attachment is mediated by spectic receptors for extracellular matrix components on the cell surface $(28,29)$. The best characterized ligand is the arginine-glycine-aspartic acid (RGD) sequence (30, 31), which is recognized by receptors of the integrin family (32). Other attachment receptors are the laminin receptors (33-35), and anchorin, a collagen receptor (36). It is likely, however, that attachment of cells to the ECM is also mediated by specific receptors for other ECM components $(37,38)$ as schematically outlined in Fig 2.

\subsection{Chemical composition}

Unlike most other biological membranes, such as plasma and organelle membranes, BM contain little or no lipid (39). The BM constituents are highly insoluble because of many covalent and non-covalent interactions. Consequently the separate components are difficult to isolate, which has hampered their structural characterization in man.

The study of BM biochemistry has been facilitated through the availability of BM producing neoplasms, which can be transplanted into lathyritic animals. These models, including the mouse Engelbreth-Holm-Swarm (EHS) tumor (40) and the rat yolk sac carcinoma (41, 42), have allowed the recognition and chemical characterization of the most important BM components. The major constituents, inchding type IV collagen, laminin, heparan sulphate proteoglycan and entactin/nidogen have been found in nearly all BM. It is likely, however, that many more BM components exist. We will first discuss the characteristics of the $\mathrm{BM}$ components found in all $\mathrm{BM}$ and will follow with a discussion of $\mathrm{BM}$ components with a limited tissue distribution.

\subsubsection{Components of all BM}

\section{* Type IV collagen}

Type IV collagen is the structural component of the BM and has a molecular weight of about $550-600 \mathrm{kD}(2,39)$. Type IV collagen consists of two distinct peptide chains, $\alpha 1$ (IV) and $\alpha_{2}$ (IV), assembled into a triple helical structure. Recently two new peptide chains were found: an $\alpha_{3}(\mathrm{IV})$ and (tentatively) $\alpha_{4}$ (IV)-chain (43). Different homo- and heterotrimers can be formed, which might show tissue or cell specific distribution. This area has, however, not been fully explored as yet. Type IV collagen differs from the interstitial collagens (type I, II and III) in its multidomain structure (44).

Furthermore the triplet sequence Gly-X-Y shows frequent interruptions in which $X$ or $Y$ often is proline or hydroxyproline (45). The type IV collagen molecule consists of a major triple helix which is connected at its amino-terminal domain with three other amino-termi- 


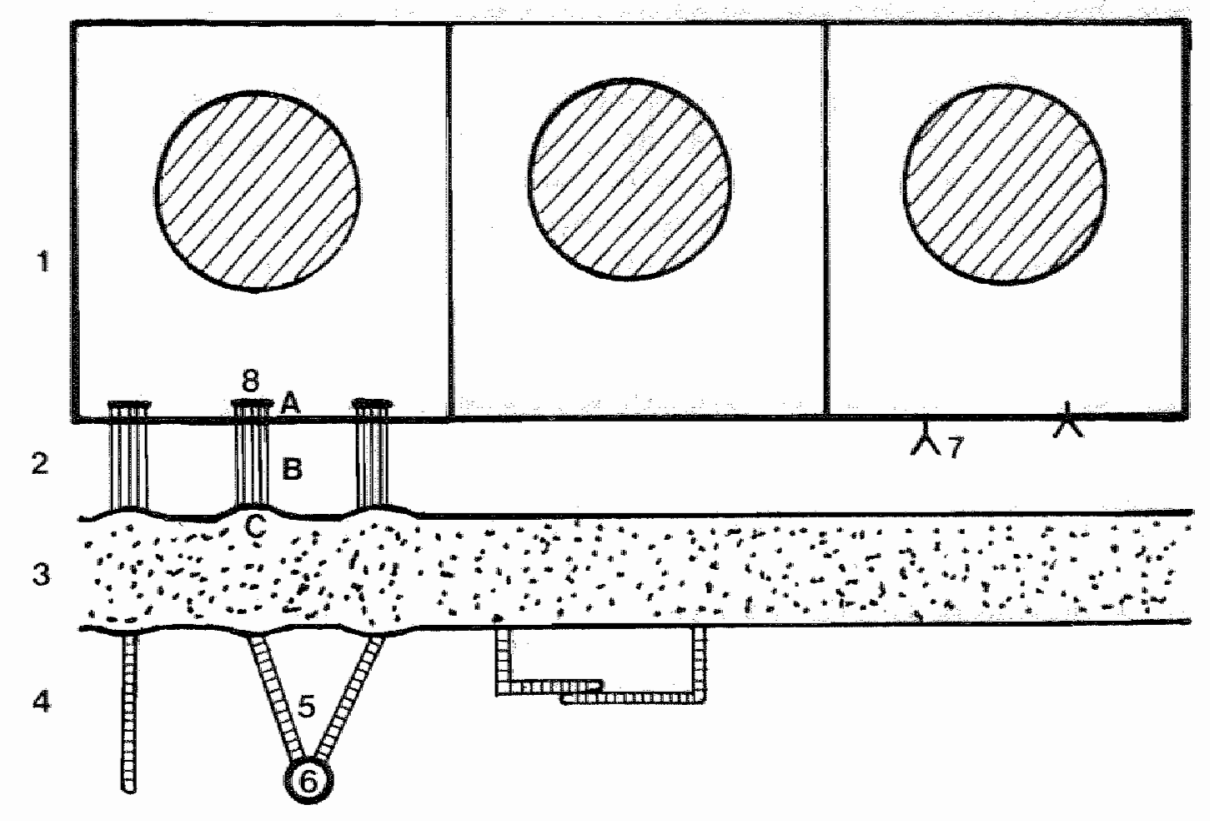

Figure 2. Schenatic drawing of the basement membrane and its attachment properties to epithelial cells and underlying stroma, $1=$ epithelium, $2=$ lamina lucida, $3=$ lamia densa, $4=$ lamina fibroreticularis, $5=$ anchoring fibers, $6=$ anchoring plaques, $7=$ extracellular matrix receptors, $8=$ hemidesmosonics ( $6=$ intrncellular attachment plaque, $b=$ anchoring filaments $\mathrm{c}=$ subbasal dense plate).

nal domains, party by covalent interactions, which together form the 75-domain (Mw 25 kD) (46-48). The globular carboxy-terminal domain is another cross-linking site, particjpating in the formation of a three dimensional matrix. Here, two type IV collagen mole. cules are connected with each other, partly by disulfide bonds and partly by covalent crosslinking, to form the non-collagenous (NC1) domain (Mw 160-170 kD) (49-51). Six globular end-regions assemble in a hexameric configuration. Interactions along the type IV col. lagen molecule can also initiate lateral assenbly (52). Within the triple helix, ancuher moncollagenous segment can be found which has been designated as the NC2-domain (Mw II) KD N. This segment contains triple-and non-triple helical sequences. The NC2 doman acis presumably as a flexible hinge (39). Type IV collagen is insoluble in tissues due to the lopmation of large networks which are stabilized by disulfide bridges and nonreducilale cross$\operatorname{links}(2,39,5)$. 
Laminin is a $900 \mathrm{kD}$ noncollagenous glycoprotein, composed of several fragments that form a asymmetric cross-shaped structure. By immuno-electron microscopy laminin can be detected throughout the entire BM but with a higher concentration in the lamina lucida $(2,53)$. Some investigators found laminin exclusively in the lamina lucida (54-56). By rotary shadowing electron microscopy, laminin appears as a cruciform molecule with one long arm ( $75 \mathrm{~nm}$ ), which contains a large globular end-domain, and three short arms (35 $\mathrm{nm}$ ), each with a terminal globular end-domain and another globular domain in the centre of the molecule. These arms are interconnected by disulfide bonds. Globular domains at the erd of the short arms bind to type IV collagen (57). The central part of the laminin moleculle binds to cell surfaces via plasma membrane receptors $(58,59)$. Binding to heparar sulphate proteoglycan is mediated by specific domains on the long arm (60).

Laminin has several biological functions. It plays a role in cell attachment, cell spreading, mitogenesis, neurite outgrowth, morphogenesis and cell movement (3). Furthermore laminin is an important structural component of the BM. Because it binds to type IV collagen, heparan sulphate proteoglycan and entactin (37). It is thought that laminin acts as at major linker holding together the entire BM and thus determine its architecturat properties.

\section{* Heparan sulphate proteoglycan}

Heparan sulphate proteoglycan (HSPG) consists of a core protein and glycosaminoglycan side chains $(61,62)$. As much as 50 to $80 \%$ of the entire molecule consists of glycosaminoglycans (62). The core protein of HSPG from the bovine glomerular BM (MW 128 $\mathrm{kD}$ ) has been identified and appears to be unique for BM HSPG (62). HSPG occurs in the BM predominantly in the lamina lucida where it forms clustered aggregates (63). Other investigators have detected HSPG also in the lamina densa (64). HSPG probably plays a role in the attachment of cells to BM and, through its anionic properties, in the regulation of glomerular filtration $(63,65)$. In addition to HSPG, proteoglycans with chondroitin- and dermatan sulphate side chains have been found in BM (66).

\section{* Entactin/nidlogen}

Entactin is a major BM component, with a molecular weight of $150 \mathrm{kD}$. It is a sulfated glycoprotein and was first discovered by Carlin et al. (67. It was rediscovered by Timpl et al. (68) and named nidogen. The protein is highly susceptible to proteolysis $(68,69)$. Its self aggregating tendency and affinity for laminin, fibronectin and type IV collagen (70) strongly suggest that the molecule has a bridging function within the BM. Entactin has no affinity for heparan sulphate proteoglycan (71). One entactin molecule forms a complex with laminin by attachment to one of the short arms of laminin, near to the center of the cross (72). Recently the complete amino acid sequence has been derived from sequencing 
cDNA clones (73). It was shown that entactin has homologous sequences with epidemal growth factor and low density lipoprotein receptor.

\section{* $L D A-1$}

A newly discovered BM component but still incompletely characterized is the antigen detected by the LDA-1 monoclonal antibody. By immunohistochemistry the LDA-1 epitope is localized in the lamina densa of all BM. The epitope is collagenase insensitive and protease sensitive, suggesting that it is of noncollagenous nature (74).

\subsubsection{Components with a limited tissue distribution}

The previously mentioned components are present in almost all BM. Many other substances have been found in BM but with a limited distribution (only in some BM) and/or not restricted to the BM (occurring also in interstitial stroma).

\section{* Anchoring fibers}

Anchoring fibers occur in the lamina fibroreticularis, and anchor the BM to the underlying mesenchyme. Anchoring fibers are found in BM of tissues of ectodermal origin, such as BM of the epidermis and the epidermal adnexa. Type VII collagen is the major structural component of anchoring fibers $(75,76)$. Anchoring fibers form horseshoe shaped structures, originating from and inserting into the lamina densa, or extending perpendicularly into the upper regions of the mesenchyme $(24,77)$. In the skin anchoring fibers are often associated with amorphous dermal (anchoring) plaques, which are not BM undulations. These plaques contain type IV and VII collagen (78). Antibodies specific for anchoring fibers (AF-1 and AF-2, LH 7:2, KF-1) have been generated (79-81). Monoclonal antibodies to type VII collagen have also been made (76). These antibodies bind exclusively to the dermal/epidermal junction, sometimes including the junctions of the epidermal adnexa and the epithelial BM in oesophagus and trachea.

\section{* Chondroitin sulphate proteoglycan}

Chondroitin sulphate proteoglycan has been observed in small amounts in the dermal/epidermal junction of the human skin BM $(66,82)$.

\section{* Type V collagen}

Type V collagen has been described as a BM component $(2,83)$, although it is now generally regarded as an interstitial rather than a BM collagen. Type $V$ collagen is not easily detected in the interstitium because of its intrafibrillar organization at the interior of type 1 and/or type III collagen fibers (84-86). 


\section{* Fibronedin}

Fibronectin is a BM associated molecule thather than a true BM component (2) It is not confined to angle BM layer (87), it occurs in variable amounts in different $B M$ and the BM of the same kind difer with regards to their content of fibronectin. Fibronectin is also found in the interstitum and in the circulation $(2,88)$.

\subsubsection{BM heterogeneity}

So far we have mainly discussed the characteristics common to all or most BM. It has become increasingly dear that BM in different vissues show characteristic variations in structure and composition. Furthermore under pathological conditions BM may show additional characteristic alterations contributing even more to the general BM heterogeneity.

\section{$1,3.3,1$ Normall variations}

\section{Morphology}

By electron microscopy, the BM consists of at least two layers: the lamina lucida and lamina densa. The lamina fibroreticularis, containing the anchoring fibers, is present only in the BM of the epidermis and epidermal adnexa, glandular epithelium of breast and prostate, squamous epithelium of the tongue, oesophagus, and vagina, and ciliated epithelia of the trachea and bronchus (76).

The glomerular BM is a unique structure since it consists of a fused endothelial and epithelial BM. Thus it appears as a trilaminar layer with a duplicated lamina densa, sandwiched between an epithelial lamina rara externa and an endothelial lamina rara interna (2). The only ot Jer BM of this appearance is the pulmonary alveolar BM, formed also from fused endothelial and epithelial BM.

Ultistructurally the lamina densa varies somewhat in thickness: it is often thicker where hemidesmosomes occur (27). This observation suggests that components of the subbats dense plate of the hemidesmosome might be intertwined with the BM components.

Pericellular BM may appear by electron nicroscopy as a continuous or discontinuous layer. Thus e in myocytes, it appeass continuous whereas myofibroblasts are surrounded by an interupted BM. Patches of BM components can be visudized as dense material, surrounding the myofibroblasts and containing at least type IV collagen, laminin and heparan sulphate proteoglycan (89-91). Fenestrations of the BM have been observed in rat and monkey intestinal villi, with a higher number of fenestrations above the Peyer's patches (92,93). These holes in the BM might represent temporary tracks created by lymphocytes migrating from the lamina propria to the epithelium. In the rat liver, the hepatic extracellular space (space of Disse) has no linear BM. Small patches of type IV collagen without laminin can be observed $(94,95)$. The discontinuous BM facilitates the rapid exchange of 
macromolecules between plasma and hepatocyte. However, in cirrhosis the BM becomes linear and type IV collagen and laminin are codistributed, transforming most of the hepatic sinusoids into capillaries.

\section{* Composition}

Although type IV collagen has been described as a structural component of all BM, type IV collagen does not appear to be present in the central comeal basement membrane (9699), suggesting that the central cornea has a structurally different BM. Furthermore normal BM components can show variations in the molecular conformation. Different immunohistochemical staining patterns for laminin in different tissues have been demonstrated using monoclonal and polyclonal antibodies to different epitopes of Jaminin (100, 101). This is also suggested by experiments with protease treatment of tissue sections which have shown that tissues have different protease susceptibility, pointing towards qualitative differences in the BM components (102).

BM heterogeneity is reflected also in the concentration of certain BM components, detected biochemically (2). In lens capsule $90 \%$ of the total dry weight is type IV collagen, whereas the glomerular BM contains $45 \%$ and the Reichert's membrane only $25 \%$ type IV collagen (23),

Because BM are highly cross-linked structures, their components cannot be isolated ealsily and extensive enzyme treatment is most often needed for biochemical analysis. Through this treatment BM components may be lost or may disintegrate and components which occur in very low amounts could remain undetected (103). Therefore, new approaches have to be derived such as e.g. production of monoclonal antibodies to native BM components. This approach may lead to the detection of hitherto unknown BM constituents (103106), although the characterization of new components could pose new and often unsurroundable obstacles.

\subsubsection{Pathologic variation}

Under pathologic circumstances BM may show alterations in morphology and composition exceeding the variation encountered in normal tissues. Investigations concerning these alterations have yielded important information with regard to the structure and composition of the normal BM but also shed light on the role of the BM in the pathogenesis of valrious diseases.

\section{*orphology}

In various pathological conditions $\mathrm{BM}$ morphology shows characteristic allterations. Thus in diabetic microangiopathy capillary BM are thickened. In contrast, in the thin BM glomerulopathy and sometimes in Alport's syndrome, the glomerular BM is abnormally thin. Finally, in neoplasia BM may become discontinuous and irregularly thickened. 
Vascular $\mathrm{BM}$ thickening is a common feature in diabetes mellitus. This could be due to a decreased content of heparan sulphate proteoglycan in these patients, in combination with an increase in the concentration of type IV collagen and laminin. BM thickening might occur as a compensatory phenomenon in the glomerular BM in order to restore the altered $B M$ porosity and malfunction in filltration due to the loss of heparan sulphate proteoglycan $(2,107,108)$. In lipoid proteinosis the BM appears multilamellar or reduplicated (123, 124).

In contrast to BM thickening, early stages of Alport's disease are marked by diffuse thinning and splitting of the glomerular BM takes place (109). In thin BM nephropathy, BM thinning was observed with quantitative electron microscopy in glomeruli from a subset of patients with persistent microscopic erythrocyturia (110).

Tumor invasion can be defined as extension of neoplastic cells beyond the natural borders of the tissue or cell type from which they are derived. As a result of this active process of invasive growth the neoplastic cells occur in tissue compartments where they do not belong. The existence of specific mechanisms for degrading BM during tumor invasion was strongly indicated by the characterization of a metalloproteinase which specifically cleaves type IV collagen (111). Other enzymes, such as cathepsins, elastase and other proteases are frequently associated with early invasion (112). Changes in biosynthesis or metabolism of BM components, which can lead to BM thickening or BM loss also affect invasiveness of tumor cells $(38,39,113,114)$.

For epithelial tissues BM are the natural borders, separating them from the connective tissue stroma. Consequently, in invasive carcinoma, the malignant epithelial cells dissolve the epithelial BM and migrate into the surrounding mesenchymal stroma. Thus it is understandable that the BM adjacent to carcinoma cells are usually discontinuous $(2,5,38,115$, 116). Immunohistochemical staining of BM has proved to be helpful to differentiate between benign or premalignant and malignant lesions: discontinuities are usually limited to malignant lesions $(38,117,118)$. However, exceptions have been found to this rule: BM discontinuities do occur in benign neoplasms and conversely, intact BM have been reported in malignant tumors $(119,120)$. In adenoid cystic carcinoma $(121,122)$ the BM becones a multilamellar or reduplicated structure due to excessive production and deposition of BM components.

\section{* Composillion}

The chemical composition of the BM in pathological conditions has not been studied extensively. Rather unique components of the BM do, however, play an important role in the pathogenesis of immune-mediated disorders, such as the Goodpasture syndrome and the group of bullous dermatoses. In all these conditions the composition of the BM changes due to the deposition of immunoglobulins. An interesting aspect of these disorders is that identification of the target antigens of these disorders may alter recognition and further characterization of new BM components. 


\section{Goodpasture syndrome}

Goodpasture syndrome (125), is characterized by pulmonary hemorrages preceding the rapidly progressive glomerulonephritis, witli which it is frequently associated. This disease is characterized by autoantibodies to BM which form diffuse linear deposits along the pulmonary and cross-react with the glomerular BM. In diffuse crescentic glomerular nephritis caused by anti-glomerular BM antibodies, pulmonary hemorrhages are caused by pulmonary venous hypertension secondary to the renal insufficiency. Althongly the epitopes of the Goodpasture autoantibodies occur in all $B M_{x}$ the primary lesions are in the lungs and kidneys. Recent studies have shown that the Goodpasture antigen is sequestered insids the hexameric structure of the NC1 domain of type IV collagen (50). Immunoblotting experiments have shown that autoantibodies from Goodpasture patients react with the monomeric M2* and dimeric D2* bands of collagenase released hexamers. These epitopes are localized in the $\alpha_{3}$ (IV) chain of type IV collagen (43).

\section{${ }^{*}$ Bullous pemphigoid}

Bullous pemphigoid is a dermal disease with formation of subepidermal bullae within the lamina lucida, between the plasma membrane of the basal cells and the lamina densa. Furthermore this disease is characterized by in vivo bound immunoreactants along the epidermal-dermal junction. By electron microscopy these immune complexes appear locally in the lamina lucida. The bullous pemphigoid antigen has been identified as a disulfidebonded $220 \mathrm{kD}$ polypeptide (126). The bullous pemphigoid antigen is a component of hemidesmosomes (127). In 70 to $80 \%$ of these patients autoantibodies of IgG-class reactive with epidermal BM can be demonstrated (64).

\section{* Cieatricial pemphigoid}

Cicatricial pemphigoid or benign mucous membrane pemphigoid is a bullous disease leading to scarring in oral and conjunctival lesions (128). Circulating autoantibodies against BM can be demonstrated in $10-40 \%$ of the patients. Frequently linear immune complexes are present in the lamina lucida of the epidermal BM. It is not unlikely that bullous pemphigoid and cicatricial pemphigoid are variants of the same disease (64).

\section{* Epidermolysis bullosa}

Epidermolysis bullosa comprises a group of rare genetic disorders which have in common the formation of blisters occurring after minor mechanical injury. It presents in a variety of forms. The so called dystrophic epidermolysis bullosa is a subset of this disorder characterised by dermal tissue cleavage below the BM. Tissue bound immunoreactants against $\mathrm{BM}$ are always present and can be demonstrated by immuno-electron microscopy in the lamina densa and below the lamina densa, in the lamina fibroreticularis. Circulating atuto- 
antibodies are present in $40 \%$ of the patients (64). The upper dermis contains decreased amounts of interstitial collagens and increased amounts of elastic fibers. By electron microscopy, the cleavage appears to be beneath the BM. This disease is related to rudimentary anchoring fibrils, which also seem to be reduced in number. The epidermolysis bullosa acquisita antigen has been chemically recognized as a $290 \mathrm{kD}$ protein which forms two subunits of $145 \mathrm{kD}$ after reduction (129).

\subsection{Aim of the study}

From the literature reviewed in the previous paragraphs it can be concluded that BM of different cells or tissues vary and that these differences occur related to the specialized functions of the cells or tissues, or due to pathologic processes.

In this thesis some aspects of the chemical and structural heterogeneity of the BM in normal and pathological siluations will be investigated, primarily with monoclonal antibodies. In chapter 2 the production of monoclonal antibodies, raised against native, non-enzymatic treated BM from amnion or glomeruli is described, as well as the immunohistochemical characterization of these monoclonal antibodies and the heterogeneous nature of their reactants recognized in the BM. In chapter 3 the molecular configuration identified by these monoclonal antibodies is investigated. The monoclonal antibodies are reactive with different epitopes of the globular carboxy-terminal end region of type IV collagen. Although some monoclonal antibodies do not react with mesenchymal BM by immunohistochemistry, the epitope can be detected after enzymatic treatment of the tissue followed by electrophoresis and immunoblotting, indicating that the type IV collagen structure is dependent upon the tissue in which it occurs.

In chapter 4 and 5 morphological and chemical heterogeneity of BM in normal organs and cells is discussed. The issue of type IV collagen being an essential structural component of all BM is discussed in chapter 4 . The immunohistochemical heterogeneity of the central epithelial corneal BM, using antibodies to type IV collagen, is reported and compared with the staining pattern of other BM components. Furthermore the ultrastructural heterogeneity of the central versus peripheral corneal epithelial BM is correlated with the immunohistochemical absence of type IV collagen. The question of the continuity of the pericellular BM in normal tissue is addressed in chapter 5 . The stromal cells of the umbilical cord were investigated ultrastructurally as cells enveloped by discontinuous BM-like deposits. Furthermore these cells were characterized by immunohistochemistry using antibodies to cytoskeletal and BM components. Their electron microscopical features were compared with those of myofibroblasts found in the desmoplastic response to neoplasia and in healing wounds. This cell type is surrounded by discontinuous patches of BM components, both in wivo and in vitro explants. Production of type IV collagen in vitro is demonstrated by northern analysis and in situ hybridization using a type IV collagen cDNA probe and immunohistochemically on celis grown on glass slides and immunoblots of tissue culture supernatants. 
Heterogeneity of BM in pathological conditions is discussed in chapter 6 and 7. One of the most intriguing questions is the origin of $\mathrm{BM}$ in epithelial neoplasms. The contribution of mesenchymal cells to the production and deposition of BM components into an epithelial/mesenchymal BM, as investigated in tumor cell lines xenotransplanted into athymic animals, is reported in chapter 6 . The origin of type IV collagen was investigated by immunohistochemistry using antibodies to rat/murine host and human specific epitopes of type IV collagen. These data were compared with the detection of mRNA, coding for type IV collagen, via in situ hybridization with a cross-species reactive type IV collagen cDNA probe. As shown in this chapter, the epithelial BM in these xenotransplanted tumor cells is of epithelial or mesenchymal origin or both. Stromal factors regulating the deposition of BM were investigated in chapter 7. Finally, in chapter 8 , the results of these studies concerning BM heterogeneity, production, origin and deposition are discussed against the background of recent literature. The prospects for future studies are briefly oullined.

\subsection{References}

1. Vracko $\mathrm{R}$ : The role of basal lamina in maintenance of orderly tissue structure. In. New trends in basement

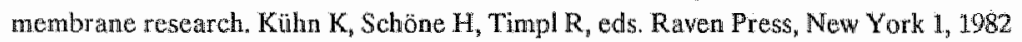

2. Martinez-Hernandez $A$, Amenta $P$ : The basement membrane in pathology. Lab Invest 48, 656, 1983

3. Kleimman HK, McGarvey ML, Hassell JR, Martin GR, Baron van Evercooren A, Dubois-Dalcq M: The role of laminin in basement membranes and in the growth, adhesion and differentiation of cells. Role of extracellular matrix in development $14,123,1984$

4. Aumailley M, Timpl R: Attachment of cells to basement membrane collagen type IV. J Cell Biol 103, 1569, 1986

5. Abrahamson DR: Postembedding colloidal gold immonolocalization of laminin to the lamina rara anterna, lamina densa, and lamina rara externa of renal glomerular basement mernbranes. J Histochem Cytochem $34,847,1986$

6. Gorstein F: The dynamic extracellular matrix. Editorial. Hum Pathol 19, 751, 1988

7. Walker F: The origin, turnover and removal of glomerular basement membrane. f Pathol 110, 233, 1973

8. A.brahamson DR, Caulfield JP: Proteinuria and structural alterations in rat glomerular basenent mem. branes induced by intravenously injected antilaminin inmunoglobulin. J Exp Med 156, 228, 1982

9. Price RG, Spiro RD: Studies on the metabolism of the renal glomentar basement mombratio. Jiol Chem $252,8597,1977$

10. Banerjee SD, Coln RH, Bernfield MR: Basal lamina of embryonic saliwary epithelial: Production by the epithellum and role in maintaining lobular morphology. I Coll Biol 73, 445, 1977

11. Dodson JW, Hay ED: Secretion of collagenous stroma by isolated epithellium grown in vitro. Exp Cell Res $65,215,1971$

12. Alitalo K, Vaheri A, Krieg Th, Timpl R: Biosynthesis of two subunits of type IV procollagen and of other basement membrane proteins by a human tumor cell line. Eur J Biochem 109, 247, 1980

13. Scarpa $S$, Modesti A, Triche TJ: Extracellular matrix synthesis by undifferentiated childhood tumor cell lines. Am J Pathol 129, 74, 1987

14. David $G$, Nusgens $B$, Schueren van der $B$, Cauwemberge $D$, Berghe van den $H$, Lapiere $C h$ collagen metabolism and basement membrane formation in cultures of mouse mammary epithelial cells. Exp Cell Res $170,402,1987$ 
15. Hornug J, Bohnert $A$, Phan Than $L$, Kreg $T$, Fueng NE: Basement membrane fomation by malignan mouse kerathocye cell lines in organotypic culture and transplants: correlation with degree of morphologic diferentiation. I Caneer Res Chin Oncol 113,325, 1987

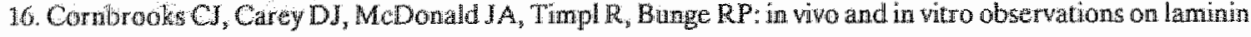
production by Schwarin cells. Froc Wat Acad Sc USA $80,3850,1983$

17. KWh U, Tinpl R, won der Mark K. Synthesis af type IV collagen and laminin in cullures of skeletal muscle colls and their trsembly on the surfaces of myotubes. Dev Biol 93, 344, 1982

18. Kuh U, Ocalan M, Tinpl R, Mayne R, Hay E, Mark won der K: Role of muscle fibroblasts in the deposition of type IV collagen in the basal lamina of myotubes. Differentiation $28,164,1984$

19. Sanderson $\mathrm{RD}$, Fitcti $\mathrm{MM}_{3}$ Linsenmayer ThR, Mayne $\mathrm{R}$ : Fibroblasts promote the formation of a continuGus basall lamina during myogenesis in witra. If Cell Biol 102, 740, 1986

20. Simon-Assmann P, Bouziges F, Arnold C, Haffen K, Kedinger M: Epithelial-mesenchymal interactions in the production of basement membrane components in the gut. Development 102, 339, 1988

21. Damjanov I, Danajanov $N$, Knowles $\mathrm{BB}$, Enguall E: Origin of laminin in the extracellular matrix of human tumor kenografts in nude mice. Virch Arch [B] 49, 45, 1985

22. Ckeutjens JPM, Havenith MG, Beek C, Vallinga M, Bosman FT: Basement membrane helerogenely derected by monoclonal antibodies. Acta Histochem (in press).

23. Kofalides $N A$, Alper $R$, Clark CC: Biochemistry and metabolism of basement membranes. Int Rev Cyol $61,167,1979$

24. Hedy RA: "The basement membrand. Interface between the epithelium and the dermis: structural feattures. Arch Dermatol 124, 709, 1989

25. Inoue S, Leblond CP: Three-dimensional network of cords: the main component of basement membranes. Am d Anatomy $181,341,1988$

26. Gipson IK, Spurr-Michaud SJ, Tisdale AS: Femidesmosomes and anchoring fibril collagen appear synchronously during dewelopment and wound healing. Develop Biol 126, 253, 1988

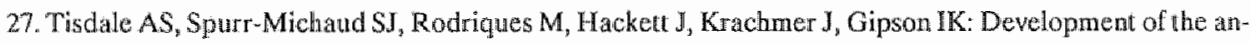
choring structures of the epithelium in rabbit and human fetal corneas. Invest Ophthalmol Vis Sci29,727, 1988

28. Aumailley $M$, Nurcombe $V$, David E, Paulsson $M$, Timpl $R$ : The cellular interactions of laminun fragnents: Cell adhesion correlates with two tragment-specilic high affinity binding sites. J Biol Chem 262, 1.1532 , 1987

29. Rouslahti E, Pierschbacher MD: Arg-gly-asp: A versatile cell recognition signall Cell 44, 517,1986

30. Piersehbacher MD, Roushatat E: Cell attachment activity of fibronectin cam be duplicated by small synthote firgments of the molecule. Natnre $262,497,1984$

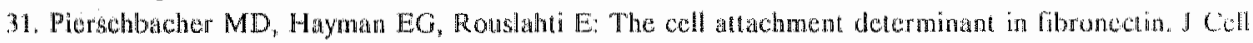
Biochem $28,115,1985$

32. Buck CA. Horwitu AF: Coll surface receptors for extracellular matrix mulecules. Ann Rev Call Biol3, $17 \%$, 1987

33. Rao NC. Barsky SH, Terranowa VP, Liolla LA: Isolation of a tumor cell laminain receptor. Biochen Biophys Res Comm 111, 804, 1983

34. von der Mark K, Kühl U: Laminin and its receptor. Biochem Biophys Acta 823, 147, 1985

35. Liotta LA, Horan Hand P, Rao CN, Bryant G, Barsky SH, Schlom J: Monoclonal antibodies to the human Laminin receptor recognize structurally distinct sites. Exp Cell Res 156, 117, 1985

36. Mollenhaver $\mathrm{J}$, von der Mark $\mathrm{K}$ : Isolation and characterization of a collagen-binding glycoprotein from chondrocyte membranes. EMBO J 2, 45, 1983 
37. Lionta LA, Nageswata Rao $C$, Wewer UM: Biochemical interactions of tumor calls with the basement membrane. Ann Rev Biochen 55, 1037, 1986

38. Liotta LA, Rao CN, Barsky SH: Tumor inwasion and the extracellutar matrix. Lab Luvest $49,636,1983$

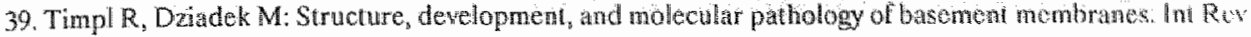
Exp: Pathol 29, 1, 1986

40. Orkin RW, Gehron P, McGoodwn, Martin GR, Valentine T, Swarm R: A murine tumor produchas a maIrix of basenent membrane. J Exp Med 145, 204, 1977

41. Wewer U: Induction of rat yolk sac carcinoma with consistent pattern of taminin, entactin, and type IV collagen biosynthesis. Acta Path Microb Immur Scand A 92, 275, 1984

42. Martinez-Hernandez A, Miller EJ, Damjanow 1, Gay S: Laminin secreting yolk sac carcinoma of the rat: biochemical and electron inmunohistochemical studies. Latb Invest $47,247,1982$

43. Saus J, Wieslander J Langeveld JPM, Quinones \$, Hudson BG: Identification of the Goodpasture antigen as the 03 (IV) chain of collagen IV.J Biol Chem 263, 13374, 1988

44. Timpl R, Weidemann I., Van Delden V, Furthmayr H, Küln K: A network model for the organzation of lype IV collager molecules in basement membranes. Eur J Biochem 120, 203, 1981

45. Schuppan D. Timpl R, Glanville RW: Discontinuities in the triple helical sequence gly-x-y of basement membrane (type IV) collagen. FEBS J 115, 297, 1980

45. Risteli $\mathrm{J}$, Bachinger $\mathrm{HP}$, Engel J, Furthmayr $\mathrm{H}_{4}$ Timpl R: 7-S collagen characterization of an unusual batsment membrane structure. Eur $\mathbb{U}$ Biochem $108,239,1980$

47. Furthmay $\mathrm{H}$, Yurchenco PD, Charonis AS, Tsilabary EC. Molecular interactions of type IV collagen and

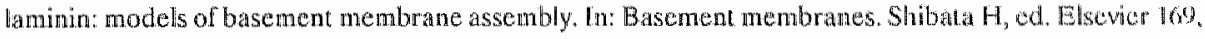
1985

48. Dixit $S \mathrm{~N}$, Robinson W, Dixit $P$, Kang AH: Immunochemistry of 7 S donain of type IV colfagen. Conncet Tiss Res $12,297,1984$

49. Weber $\mathrm{S}$, Engel J, Wiedemann H, Glanville RW, Timpl R: Subunit sirueture and assembly of the glothular domain of basement membrane collagen type IV. Eur J Biochem $139,401,1984$

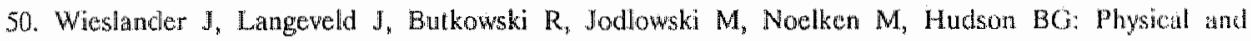
immunochemical studies of the globullar domain of type IV collagen. If Biol Chem $260,8564,1985$

51. Wieslander J, Barr JF, Butkowski RJ, Edwards SH, Bygren P, Heinegard D, Hudson BG: Goodpasture antigen of the glomerular basement membrane: localization to noncollagenous regions of type IV collagen. Immunology 81, 3838, 1984

52. Tsillibary EC, Charonis AS: The role of the main noncollagenous domain (NC1.) in type IV collagen sell. assembly. I Cell Biol 103, 2467, 1986

53. Madri JA, Roll FJ, Furthmayr $\mathrm{H}$, Foidart $J \mathrm{M}$ : Ultrastructura Localization of Fibronecth and laminin in the basement membrane. J Cell Biol 86, 682, 1.280

54. Farquhar MG: The glomerular basement mernbrane. A selective macromolecular filter. In: Cell Biology of extracelular matrix. Hay ED, ed. Plenum. Press, New York 335, 1981

55. Courtoy PJ, Timpl R, Forquhar MG: Comparative distribution of laminin, type V Vollagen, and Iibroncetin in the rat glomerulus. J Histochem Cytochen $30,874,1982$

56. Foidart JM, Bere EW, Yaar M, Renmard SI, Gullino M, Martin GR, Katz SI: Distribution and imum noelectron microscopic localization of laminin, a noncollagenous basement membrane glycoprotein. Lath Invest $42,336,1980$

57. Charonis AS, Tsilibary EC, Saku T, Furthay HA: Inhibition of laminin self-assernbly and interaction will type IV collidgen by antibodies to the terminal domain of the long arm. I Cell Biol 103, 1684, 1046

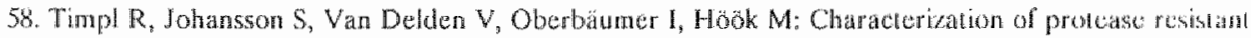

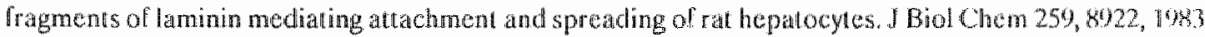


59. Terranova VP, Rorbbach DH, Martin GR; Role of laminin in the attachment of PAM 212 (epithelial) cells 10 botsentent membrane collagen. Cell 22,719, 1980

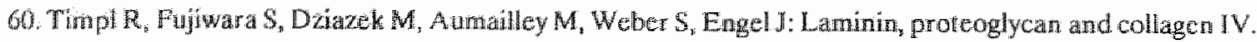
Struetural thodels and molecular interactions. In: Basement membranes and cell movernent. Ciba Found Symp to8 London: Pitman Publishing, Lud. 25, 2984

61. Parthasathy $\mathrm{N}$, Spiro RG. Characterization of the glycosaminoglycan componemt of the renal giomertlar bastanent membrine and its relationship to the peptide portion. J Biol Chem 256,507, 1981

62. Hassel JR, Robey PO, Baranch HJ, Wilczek J, Rennard SI, Martin GR: Isolation of a heparan sulphate proteoglycan from basement membrane. Proc Natl Acad Sci USA 77, 4494, 1980

63. Mynderse LA, Hassel J. Kleinman HK, Martin GR, Martinez Hernandez A: Loss of heparan sulfate prow ieoglycin from glomerular basement membrane of nephrotic rats. Lab lnvest $48,292,1983$

64. Fine JD: Cicatricial pemphigoid, bullous pemphigoid and epicernolysis bullosa acquisita antigens: ditferences in organ and species specificities and localization in chemically-separated human skin of three basement membrane antigens. Collagen Rel Res 5,369, 1985

65. Rethe HG Cotran RS, Wenkatachalan MA: Role of molecular charge in glomerular permeability: tracer studies with cationized ferritin. J Cell Biol $67,638_{n} 1975$

66. Breman MJ, Oldberg, \&, Pierschbacher MD, Ruoslahti E: Chondroitin/dermatan sulfate proteoglycan in human fetal membranes: demonstration of antigenical similar proteoglycan in fibroblasts. J Biol Chem $259,13742,1984$

67. Carlin B, Jaffe $\mathrm{R}_{*}$ Bender B, Chung AE; Entactin a nowel basal la mina associated sulfated glycoprotein. .J Biol Chem 256,5209, 1981

68. Timpl R, Dziadek M, Fujiwara $S$, Nowack $H$, Wick $\mathrm{G}$ : Midogen: a new self aggregating basement membrane protein. Eur. I Biochem 137, 455, 1983

69. Paulsson M, Deutamann R, Dziadek M, Nowack H, Timpl R, Weber S, Engel J: Purification and structurat characterization of intact and fragmented nidogen obtained from a tumor basement membrane. Eur IBiochem 156, 467, 1986

70. Dxadek M, Paulsson M, Aumailley $M$, Timpl R: Purification and tissne distribution of a small protein ( $B M-40$ ) extracted from a basement membrane lumor. Eur J Biochem 161, 455, 1986

71. Driadek M, Paulsson M, Timpl R: Idenification and interaction repertoire of the large forms of the base" ment menbrane protein nidogen. EMBO J 4, 2513, 1985

72. Paulsson M, Aumailley M, Deutzmann R, Timpl R, Beck K, Engel J: Laminin-nidogen complex. Exiracthon with chelating agents and structural characterization. Eur J Biochen 166, 11, 1987

73. Durkin ME, Chakrawarti $\$$, Bartos BB, Lit S.H, Friedman RL, Chung A.E: Amino acid sequence and donuan structure of entactin. Homology with epichermal growth factor precursor and low density lipopiotein receptor, J Cell Biol 107, 2749, 1988

74. Fine ID, Gay S: LDA-1: A ubiquitous noncollagenous lamina densa component of busement membrane detected by monoclonal antibody technique. J llvvest Dermatol 86, 286, 1986

75. Bont\% H, Morris NP, Muray LW, Sakai LY, Hollister DW, Burgeson RE: Isolation and partial chatracterization of a new human collagen with an extended triple-helical structural domain. Biochemistry $80,3168,1983$

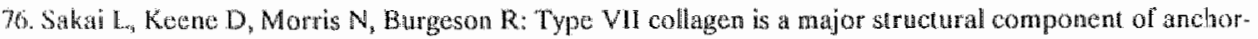
ing Libris. J Cell Biol 103, 1577, 1986

77. Patade CE, Farquhat MG: A special fibril of the dermis. J Cell Biol 26, 263, 1965

78. Koene DR, Sakai LY, Lunstrum GP, Morris NP, Burgeson RE: Type VII collagen forms an extended nelwork of anchoring tibrils. J Cell biol 104, 611, 1987 
79. Goldsmith LA, Briggaman RA. Monodonal antibodies to anchoring fibrts for the diagnosis of cptcernoIysis bullosa. J Inwest Dermatol $81,464,1983$

80. Heagerty AHM, Kennedy AR, Leigh IM, Eady RAJ: LF 722 Monoclomal antibody defines a conmon dermo-epidermal junction defect in recessiwe forms of dystrophic ejidermolysis bullosa. Jinest Derma$10184,448,1985$

81. Fine JD, Breathach SM, Hintner H, Katz SL: KF-I monoclonal antibody defines a specific basement nembrane antige defect in dystrophic forms of epidermolysis bullosa. I Invest Dermatol 82, 35, 1984

82. Fine JD: Antigenic features and structural cortelates of basement membranes. Arch Dermatol 124, 713, 1988

83. Roll FJ, Madri JA, Albert $\mathrm{I}$, Furthmayr $\mathrm{H}$; Codistribution of collagen types IV and $\mathrm{AB} 2$ in basenent nembranes and mesangium of the kidney: an immunofertitin study on ulrathin fronen sections. J Cell Biol 85, 597, 1980

84. Burgeson RE: The junction zone and the dermis. The collagens of skin. Curr Protyl Derm 17, 61, 1947

35. Burgason RE: Do banded collagen fibres contan wo or more collagen types? ISI Antas of Science Bouchumistry 88,1988

86. Fich JM, Birk DE, Menzer A, Hasty KA, Mainardi C, Linsenmayer TF Corneal collagen fibrils: Dissucion with specilic collagenases and monoclonal antibodies. Invest Ophthlamol Vis Sci $29,1125,1988$

87. Clark RAF: Potential roles of fibronectin in cutaneous wound repair. Arch Dermatol 124, 210, 1988

88. Brownell $\mathrm{AG}_{\mathrm{v}}$ Bessem $\mathrm{CC}, \mathrm{Sla}$ in $\mathrm{HC}$ : Possible functions of mesenchyme cell-derived fibronectin during formation of basal lamina. Dev Bioll $78,3711,1981$

89. Lipper S, Kalm LB, Reddick RL: The myofibroblast. Pathol Anm 15, 409, 1980

90. Secmayer TA, Schurch W, Lagace R: Myofibroblasts in human pathology. Hurn Pathol 12, 491, 1981

91. Seemayer TA, Lagace $\mathbb{R}$, Schürch W, Themo WL: The myolibroblast: biologic, pathologic, and theoreticall considerations. Pathol Annt 15,443, 1980

92. McClugage SG, Low FN, Zimny ML: Porosity of the basement membrane owerlying Peyer's patches in rats and monkeys. Gastroenterology $91,1128,1986$

93. Komuro T: Fenestrations of the basall lamima of intestinal villi of the rat. Cell Tissue Res 239, 183, 1985

94. Martincz-Hernandez A: The hepatic extracellular matrix. I. Electron immunohistochemical studies in nor. mal liver. Lab Inwest 51, 57, 1984

95. Martinez-Hernandez A: The hepatic extracellular matrix. II Electron immunohistochemical studics in rats with CCl4-induced cirrhosis. Lab Invest $53,166,1985$

96. Odermalt BF, Lang $A B$, Rülner JR, Winterhalter KH, Trüeb B: Monoclonat antibodies to luman type IV collagen: Useful reagents to demonstrata the heterotrimeric nature of the molecule. Proe Natl Aciad SCIUSA $1,7343,1984$

97. Scheimman II, Tsai C: Monoctonal antibody to type IV collagen with selective basement mombrand houlization. Lab Invest $50,101,1984$

98. Sundarcaj $\mathbb{N}$, Willson J: Monoclonal antibody to lnuman basement membrane collagen type IV. Intrinuolongy $47,133,1982$

99. Cleutjens JPM, Havenith MO, Vallinga M, Bosman FT: Absence of type IV collagen in corneal epithelial basenatent membranc. Submitted.

100. Wan $Y \mathrm{~J}$, Wu TC, Chung $\mathrm{AE}$, Damjanow $\mathbb{1}$ : Monoclonal andibodies to laminin reveal the heterogeneity of basement menbranes in the developing and adult mouse tissues. J Cell Biol 98, 971,1984

101. Let F, Engvall, E, Damjanov I: Heterogeneity of basement nembranes of the human genitourinary tract revealed by sequential immunofluorescence staining with monoclonal andibodies tom laminin. I Histochem Cytochem 34, 483, 1986 
102. Let $\mathrm{F}$, Damjand: Protedse treatment combined with immunohistochemistry reveals heterogeneing of noirmal and neoplastic basement membranes. I Histochem Cylochem $36,213,1988$

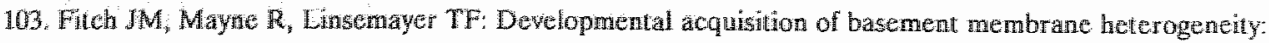
type IV collagen in the avian lens capsule. J Cell Biol 97, 940, 1983

104. Hessle $H_{5}$ Sakai $L$, Hollister $D$, Furgeson $\mathbb{R}$, Engvall $\mathrm{E}$ : Basenent membrane diversity detected by monoclonall antibodies, Differentiation $26,49,1984$

105. Verrando $P$, Ortonne J $P$, Pautrat $G, H S B-L$, Yeh CJ: Identification of a 37 kilodalton protein at the epidernal basement membrane by an antiserum to human amnion. I Invesi Dermatol $87,190,1986$

106. H1inswit K.D, Hansen D, Zimmermann A, Bruchhausen v. F. Production and immumohistochemical characterization of monoclonal anlibodies directed against renal basement membranes of rats. Histol Histopath $3,325,1988$

107. Sternberg M, Cohen-Forterre L, Peyroux J: Connectiwe tissue in diabetes mellitus; biochemical alterations of the intercellular matrix with spectal reference to proteoglycans, collagens and basement membranes. Diabet Metab 11, 27, 1985

108. Kanwar YS, Rosenzweig LJ, Linker A, Jakubowski ML: Decreased de novo synthesis of glomerular prolooglyeans in diabetes: biochemical and autoradiographic evidence. Proc Natl Acad Sci USA 80, 2272, 1983

109. Rosen S, Galvanek E, Levy M, Habib R: Progress in human pathology: glomerular discase. Hum Pathel $12,964,1981$

110. Tiebosch ATMG, Frederik PM, wan Breda Wriesman PIC, Mooy IMV, wan Rie Hi, wan de Wiel TWM, Wolters $\mathfrak{J}_{\text {, }}$ Zeppenfeldt $E$ : Thin-basement-membrane nephropathy in adults with parsistent hematuria. New Eng J Med 320, 14, 1989

111. Liota LA, Tryggvason K, Garbisa S; Hart I, Foltz CM, Shajie S: Metastatic potential correlates with enzymatic degradation of basement membrane collagen. Nature $284,67,1980$

112. Salo $T_{5}$ Liotta $L A_{n}$ Keski-Oja J, Turpeenniemi-Hujanen $T$, Tryggwason K: Secretion of basement membrane collagen degrading enzyme and plasminogen activator by transformed cells - role in metastasis. Int J Cancer $30,669,1982$

113. Havenith MG, Arends JW, Simon R, Volovics A, Wiggers T, Bosman FT: Type IV collagen immunoreactiwity on colorectal cancer: prognostic value of basement membrane deposition. Cancer $62,2207,1988$

114. Thorgeirsson UP, Turpeennieni-Hujanen T, Liotta LA: Cancer cells, components of basement membrat nes, and proteolytic enzymes. Int Rev Exp Pathol 27, 203, 1985

115. Bosman, F, Havenith M, Cleutjens J: Basement membranes in cancer. Ultrastruct Pathol 8, 291, 1985

116. Albrechtsen R, Wewer UM, Liotta LA: Basement membranes in human cancer. Pathol Annu 251, 1986

117. Barsky SH, Siegal GP, Janouta F, Liotta LA: Loss of basement membrand conponents by invasiwe umors but not by their benign couterparts. Lab Inwest $49,140,1983$

118. Burtin $P$, Chavanel $O$, Foidart JM, Martin E: Antigens of the basenent membrane and the peritumoral stroma in human colonic adenocarcinomas: an immonolluorescence study. Int I Cancer 30, 13, 1982

119. MCArde IP, Rolf BT, Multer HK, Murphy WH: The basal lamine in basal cell carcinoma, Bowen's diseasce, squmous cell carcinoma and keratoacanhomat an immunoperoxidase study using an antibody to type IV collagen. Pathology 16, 67, 1984

120. Gusterson BA, Warburton MJ, Mitchell D, Kraft N, Hancock W: Inwading squamous cell carcinoma can retain a basal hamina: An immunohistochemical study using a monoclonal antibody to type IV collagen. Lat Invest $51,82,1984$

121. Kallioinen M: Inmunoelectron microscope demonstration of the basement membrane components laminin and type IV collagen in the dermal cylindroma. J Pathol 147, 97, 1985 
122. Barsky SH, Hamah JB: Extracellular hyaline bodies are basement membrane accurnalaions. Am J Pa. thol $87,455,1987$

123. Moy LS, Moy RL, Matsuoka L, Ohta A, Uito I: Lipoid proteinosis ultrastructurat and biochemical st wdies. J Am Acad Dermatol 16, 1193,1987

124. Fleischmajer $R$, Krieg $T$, Dziadek $M$, Altchek $D$, Tumpl $R$; Ultastmeture and composition of conncetive tissue in hyalinosis cutis et mucosae skin. I Invest Dermatol $82,352,1984$

125. Goodpasture EW: The significance of certain pulnomary lesions in folation to tho clioblogy of inthenea. Am IMed Sci 158, 864, 1919

126. Stanley JR, Hawley-Nelson P, Yuspa SH, Shewach EM, Katz SI: Characterization of bullous pemphigsoil antigen: A unique basement membrane protein of stratifed squamous epithelia. Ceil 24,897, 1981

127. Anhall GJ, Jampel HD, Patel HP, Diaz LA, Mutasim DF: Bullous pemphigoid antoantibodies ane markers of comeal epithetial henidesmosomes. Invest Opthalmol Vis Sci $28,903,1987$

128. Fine J-D, Neises $G$, Katz S: Immunofluorescence and imunuoelectron nicroscopic studies in cicatricial pemphigoid. J Invest Derm $82,39,1984$

129. Woodley DT, Briggaman RA, O'Keefe EJ, Inman AO, Queen LL, Gammon WR: Identification of the skin basement-membrane autoantigen in epidermolysis bullosa acquisita. N Engl 3 Med 310, 1007, 1984 



\section{Chapter 2}

\section{Monoclonal antibodies to native basement membranes reveal heterogeneous immunoreactivity patterns*}

*Cleutjens JPM, Haventh MG, Vallinga M, Beek M, Bosman FT.

Submitted for publication. 


\subsection{Introduction}

Until now it has been described that all basement membranes (BM) contain type IV collagen, laminin, heparan sulphate proteoglycan and entactin (1). Type IV collagen constitutes the basic component of the BM to which the other components are attached (2). Although the basic structure of all BM is identical, it is likely that BM in different anatomic sites have unique components, which might be related to a specific local function. Unique tissue specific BM characteristics have been recognized in some clinical syndromes. Thus bullous pemphigoid, is characterized by autoantibodies against the bullous pemphigoid antigen in the epidermal BM (3) and the Goodpasture syndrome, characterized by pulmonary hemorrages preceding the rapidly progressive glomerulonephritis, with which it is frequently associated. This disease is characterized by autoantibodies to BM which form diffuse linear deposits along the pulmonary and cross-react with the glomerular BM (32). Although the epitopes of the Goodpasture autoantibodies can be found in all basement membranes after appropriate pretreatment, the disease affects mainly the lungs and kidneys (4).

Additional findings suggesting BM heterogeneity derive, from immunohistochemical (8) and lectin histochemical studies $(5,6)$. Several investigators have reported heterogeneous $\mathrm{BM}$ staining patterns with monoclonal antibodies (MA) against laminin $(7,8)$ or against type VIl collagen $(9,10)$. Others have induced MA against amnion BM $(11,12)$ or human glomerular BM (13), which display heterogeneous BM staining patterns. Heterogeneous $B M$ reactivity with $M A$ generated against human fetal membranes and human glomerular basement membranes will be reported in this chapter.

\subsection{Materials and methods}

\subsubsection{Immunogens}

Human amnion was separated from chorion and the amniotic BM was isolated by chemical and mechanical treatment as described by Liotta et al. (14). Briefly, amnion was washed one hour in distilled water with $2 \mathrm{mM} \mathrm{N}$-ethyl maleïmide (NEM), extracted one hour in distilled water with $1 \mathrm{M} \mathrm{NaCl}, 20 \mathrm{mM}$ EDTA, $2 \mathrm{mM} \mathrm{NEM}$ and finally one hour in distilled water with $4 \%$ de-oxycholate. After each step the membranes were mechanically treated with a rubber policeman to remove amniotic epithelial cells and most of the interstitial stroma. Types IV and $\mathrm{V}$ coll lagen were isolated from the human placenta by pepsin digestion and limited salt precipitation, followed by column chromatography as described earlier (15). Human glomerular basement membrane extracts were kindly provided by Dr. B. van den Heuvel (Nijmegen). These had been prepared according to the procedure described by Langeveld et al. (16). In short human kidney cortex was sieved sequentially on several mesh sizes. Glomeruli were obtained at mesh sizes between 90 and $125 \mu \mathrm{m}$. The glomeruli were lysed in $0.1 \% \mathrm{NaN}_{3}$ and $1 \mathrm{mM}$ EDTA, centrifuged and subsequently incu- 
bated $5 \mathrm{~h}$ with $4 \%$ sodium de-oxycholate, treated $2.5 \mathrm{~h}$ with deoxyribonuclease ( 59 Kunitz units $/ \mathrm{ml}$ ), washed with distilled water and lyophilized.

\subsubsection{Immunization and monoclonal antibody production}

Balb/c mice were immunized by subcutaneous implantation of stripped amniotic membranes and boosted with amnion supplemented with types $\mathrm{V}$ and $\mathrm{V}$ collagen and an $8 \mathrm{M}$ urea extract form amniotic membranes (17), as extensively described in chapter 9.1 . Immune spleen cells were fused with $\mathrm{Sp} 2 / 0$ cells (18) and resulting hybridomas were selected by immunohistochemistry on placental membranes, following standard techniques with minor modifications as outlined in chapter 9.2 .

\subsubsection{Antibodies}

Antibodies used in this study were the monoclonal antibodies generated as described above and furthermore monoclonal and polyclonal anti-type IV collagen antibodies (15), monoclonal and polyclonal anti-laminin antibodies (7), a monoclonal anti-type VII collagen antibody (9) and a monoclonal anti-heparan sulphate proteoglycan antibody. The specificities of these antibodies are outlined in chapter 9.4.

\subsubsection{Tissues}

Samples of various human tissues, obtained at autopsy or from surgical specimens, were snap frozen in isopentane, quenched in liquid nitrogen. Frozen tissues were cryostat sectioned at $4 \mu \mathrm{m}$. Immunocytochemistry was performed as described for hybridoma testing. In addition, for immunofluorescence, rabbit anti-mouse $\mathrm{IgG}$ conjugated with fluoresceine isothiocyanate (Dakopatts) was used as a second step.

\subsubsection{Digestion of frozen sections}

Unfixed frozen sections were incubated during 30 minutes at room temperature (RT) or $37^{\circ} \mathrm{C}$ with various concentrations of the following enzymes: trypsin (Boehringer, Mannheim. FRG), 0.05-0.5\% pepsin (Boehringer, Mannheim, FRG) in 0.1 $\mathrm{N} \mathrm{HCl} \mathrm{(30} \mathrm{min,} \mathrm{RT),}$ 0.01-0.10\% pronase (Boehringer, Marinheim, FRG) in $50 \mathrm{mM}$ Tris- $\mathrm{HCl}, \mathrm{pH} 8.0,(30 \mathrm{~min}$, RT), collagenase (Clostridium histolyticum; Sigma, St. Louis, USA) and 0.05-0.1\% hyaluronidase (Cooper Biomedical) in 0.1 M sodium phosphate buffer (0.15 $\mathrm{M} \mathrm{NaCl}$, pH 4.5,30 min, RT). Furthermore the sections were eluted with $6 \mathrm{M}$ guanidinium hydrochloride (GuHCl), or $8 \mathrm{M}$ urea in $50 \mathrm{mM}$ sodium acetate, $50 \mathrm{mM}$ EDTA, pH $6.5,30 \mathrm{~min}, \mathrm{RT}$, or treated with 0.1-0.5 $\mathrm{M} \mathrm{HAc}, 30 \mathrm{~min}, \mathrm{RT}$. These procedures were chosen to grossly determine the nature of the detected antigen (enzymes) or to unmask possible hidden epitopes (tissue extraction with $\mathrm{GuHCl}$ or urea, tissue swelling with HAc). 


\subsubsection{Chemical cleavage of the epidermal basement membrane}

Fragments of human abdominal skin, approximately $4 \mathrm{~cm}^{2}$, obtained at autopsy, were incubated during 24 hours at $4{ }^{\circ} \mathrm{C}$ with $1 \mathrm{M} \mathrm{NaCl}$ as described by Fine et al. (19). After incubation, the epithelial cell layer could be removed by pulling the epidermis from the dermis with a forceps. The plane of cleavage appeared to be within the basement membrane. After separation, the epidermal and dermal layers were frozen and sectioned. The immunoreactivity of the different layers with the various antibodies was investigated to localize the epitopes of the MA into the different layers of the BM.

\subsection{Results}

\subsubsection{Hybridomas obtained}

Testing of hybridoma culture supernatants on frozen sections of intact placental membranes resulted in twenty BM immunoreactive hybridomas (e.g. BM restricted and/or amniotic epithelial cell reactive and/or interstitial stroma reactive).

The pattern of reactivity on human fetal membranes of clones 1052 (IgG1), 1053 (IgG1), and 1065 ( $\mathrm{IgG} 2 \mathrm{~b}$ ) with a predominantly BM restricted staining pattern, is summarized in Table 1. Of the species tested (including man, rat, rabbit, swine, and dog) these MA reacted only with human tissues. All MA stained the amniotic BM, whereas none were reactive with placental BM. Clone 1065 showed weaker immunoreactivity of the BM in combination with cytoplasmatic reactivity of amnion epithelium, some chorionic epithelial cells and trophoblastic cells of the villi. All MA stained the chorionic BM, but MA 1052 and 1053 showed a much more intense immunoreactivity than 1065. All MA showed pericellular immunoreactivity of chorionic epithelial cells. Reactivity was found only with unfixed cryostat sections. Even mild fixation ( $3 \mathrm{~min}$, RT, 2-4\% phosphate buffered paraformaldehyde) destroyed the immunoreactivity.

The MA 1042 and 1043 directed against pepsin cleaved type IV collagen (15) and clone 1087 ( $\lg \mathrm{g} 2 \mathrm{~b}$ ) reacted with all basement membranes in the fetal membranes and placental tissue.

\section{3 .2 Reactivity on human tissues}

Human speciffic anti-type IV collagen reactive MA (clones 1042 and 1043) stained nearly all BM. The immunoreactivity of MA 1087, obtained after immunization with human glomerular basement membrane extracts, showed the same pattern of immunoreactivity as MA 1042 and 1043. Only the central epithelial basement membrane of the cornea did not show immunoreactivity with MA 1042,1043 and 1087, whereas antibodies to laminin and heparan sulphate proteoglycan showed uninterrupted staining of the corneal epithelial basement membrane (20). 
Table 1. Immunoreactivity of the monoclonal antibodies with fetal membranes and placenta

\begin{tabular}{|c|c|c|c|c|c|c|c|}
\hline \multirow[b]{2}{*}{$\begin{array}{l}\text { Monoclonal. } \\
\text { Antibody }\end{array}$} & \multicolumn{2}{|c|}{ amnion } & \multicolumn{3}{|c|}{$\begin{array}{l}\text { chorion } \\
\text { cytotrophoblast }\end{array}$} & \multicolumn{2}{|c|}{ placenta } \\
\hline & BM & ic & $B M$ & $p c$ & $\mathrm{ic}$ & $\begin{array}{l}\text { BM } \\
\text { villus }\end{array}$ & trophoblast \\
\hline 1042 & $t+$ & - & + & + & - & + & - \\
\hline 1043 & $+t$ & - & + & + & - & + & - \\
\hline 1087 & ++ & - & + & + & - & + & - \\
\hline 1052 & ++ & - & ++ & + & - & - & - \\
\hline 1053 & $+t$ & - & $+t$ & + & - & - & - \\
\hline 1065 & + & + & + & + & $+1-$ & - & $+1-$ \\
\hline
\end{tabular}

$\mathrm{BM}=$ basement membrane; $\mathrm{ic}=$ intracytoplasmic; $\mathrm{pc}=$ pericellular; + to = strong positive; $+=$ positive; $-=$ negative; $+1-=$ moderate immunoreactivity

MA 1087 displayed less intense immunoreactivity than MA 1042 and 1043, which showed staining intensity comparable to that with antibodies to laminin and heparan sulphate proteoglycan. This heterogeneity in staining intensity was most clearly seen in the human liver. MA 1042 and 1043 showed intense immunoreactivity with the hepatocyte or sinusoidal basement membrane, whereas MA 1087 and antibodies to laminin and heparan sulphate proteoglycan showed very weak immunoreactivity.

The reactivity of the other MA is summarized in Table 2 and Fig 1. MA 1052 and 1053 homogeneously stained BM of epidermis and epidermal adnexa, such as sebaceous and sweat glands and hair follicles. Furthermore BM of glandular epithelium of breast and prostate, squamous epithelium of the tongue, oropharynx, oesophagus, and vagina, and ciliated epithelia of the trachea and bronchus as well as alveolar BM in the lung were stained. In the lung no reactivity occurred with the endothelial basement membrane.

In the gastrointestinal tract epithelial BM of the superficial crypt (colon) or villous (small intestine) structures was observed, whereas deeper in the mucosa BM reactivity was absent. No reactivity was obtained with renal or vascular BM or with BM of fat, muscle-, or Schwann cells.

MA 1065 in contrast to the staining pattern of MA 1052, 1052 and 1087 did not react with BM in the lung and the gastrointestinal tract. However, the tracheal epithelial BM and the BM of the oesophageal mucosa reacted with this MA. Furthermore MA 1065 showed, in addition to basement membrane staining, strong pericellular immunoreactivity with the basal cells of the epidermis. MA 1065 did not react with renal or vascular BM or with BM of fat-, muscle-, or Schwann cells. 

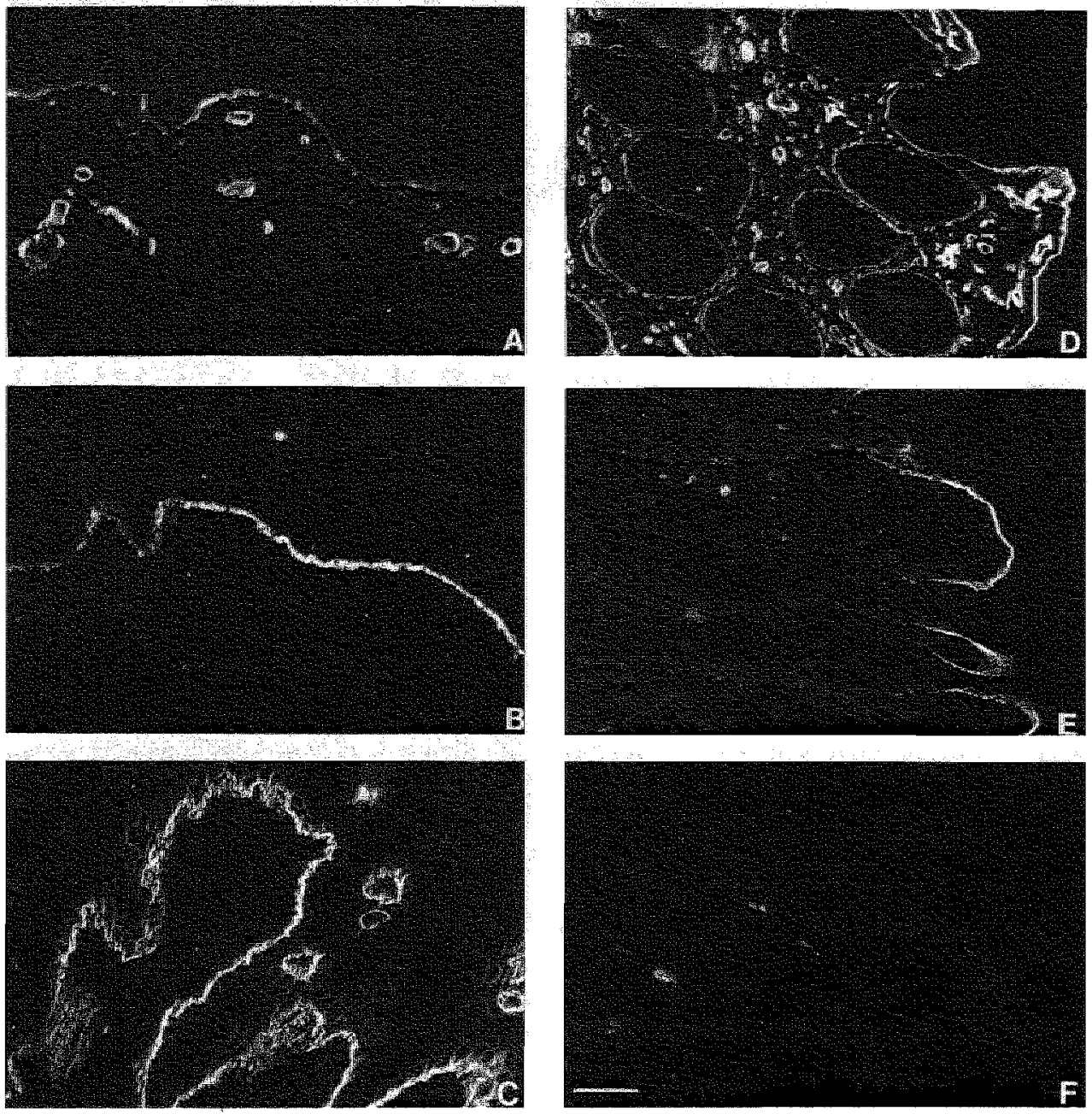

Figure 1. Indired immunofluorescence staining of cryostat sections of human skin $(A, B, C)$ and colon $(D, E, F)$. A and $D$ ire stained with anti-type TW collagen antibody (clone 1042). Note continuous labeling of all BM. B and $\mathrm{E}$ are stained with clone 1052 . Note staining of the epithelial BM only. In colon (E) staining is most intense at the luminal border. $C$ and $F$ are stained with clone 1065. Only epidermal BM membrane is stained. Furthermore the basal cell layer shows pericellular labeling. Scale bar $=10 \mu \mathrm{m}$. 
Table 2. Immunoreactivity of the monoclonal antibodies with BM of human tiscues

\begin{tabular}{|c|c|c|c|c|c|}
\hline \multirow[b]{2}{*}{ Tissues } & \multicolumn{4}{|c|}{ monodonal antibody } & \multirow[b]{2}{*}{$\begin{array}{l}4 \mathrm{E} 10 \\
\mathrm{HSPG}\end{array}$} \\
\hline & $\begin{array}{l}1042 / \\
1043\end{array}$ & 1087 & $\begin{array}{l}1052 \\
1053\end{array}$ & 1065 & \\
\hline \multirow{2}{*}{$\begin{array}{c}\text { Skin: epidermis } \\
\text { adnexa }\end{array}$} & + & + & + & $+(p c)$ & + \\
\hline & + & + & + & + & + \\
\hline Cornea & - & - & $+\frac{1}{1}$ & $+(p c)$ & + \\
\hline Breast & + & + & $\frac{4}{6}$ & + & + \\
\hline Tongue & + & + & + & + & + \\
\hline Oropharynx & + & + & + & + & + \\
\hline Vagina & + & + & + & + & + \\
\hline Oesophagus & + & + & + & + & + \\
\hline Trachea & + & + & + & + & + \\
\hline Bronchus & + & + & + & - & + \\
\hline Stomach & + & $\frac{4}{3}$ & + (sup) & - & + \\
\hline Small intestine & + & + & + (sup) & - & + \\
\hline Colon & + & + & $+($ sup $)$ & - & + \\
\hline Lung & + & + & + & - & +. \\
\hline Liver & ++ & $+1-$ & - & - & +10 \\
\hline Kidney & $+t$ & ++ & - & - & + \\
\hline
\end{tabular}

$+=$ positive; $-=$ negative; $+1-=$ weak immunoreactivity; sup = superficial epithelinm;

$\mathrm{pc}=$ pericellular immunoreactivity

\subsubsection{Chemical cleavage of the epidermal BM}

The sodium chloride split epidermal BM was frozen, sectioned and stained with the available antibodies (Table 3 and Fig 2). MA 1065 showed very strong pericellular staining of basal epidermal cells and adherent basement membrane components but no staining of BM adberent to the dermis. Laminin was predominantly found in the epidermal part but also faintly in the BM layer adbering to the dermis. Antibodies to type IV collagen, however, predominantly stained the BM-layer adhering to the dermis, whereas the epidermal acherent BM components showed only faint immunoreactivity. The MA 1052, 1053 and antibodies to type VII collagen reacted exclusively with the BM segment adherent to the dermis, indicating that the epitope is localized in the (sub)lamina densa. 

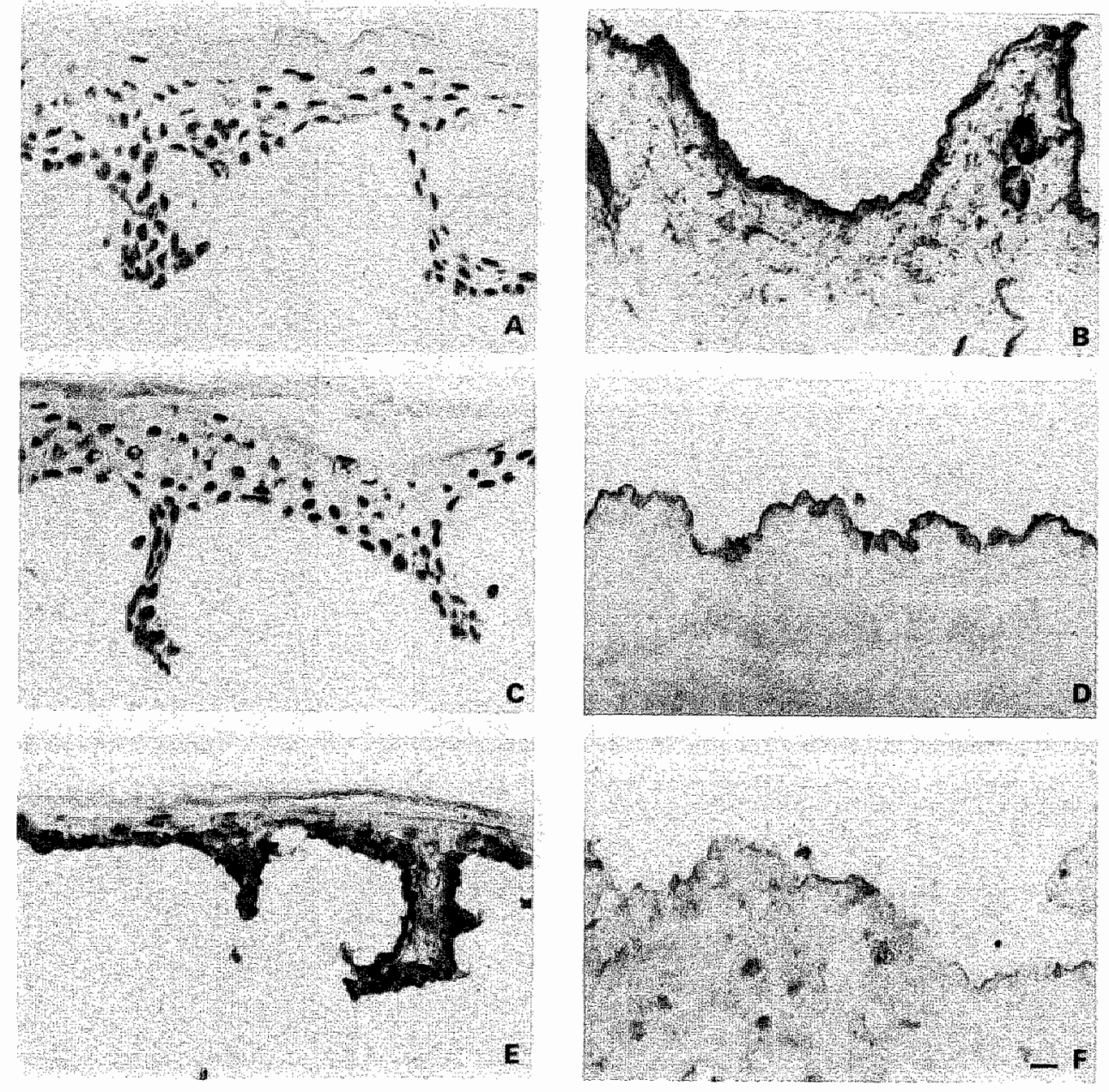

Figure 2. Immunoperoxidase staining of cryostat sections from $\mathrm{NaCl}$ cleaved human skin. Epidermal face (A, $C_{y}$ E). Dermal face $(B, D, F)$. A and 1 are stained with $M A$ 1042. $C$ and D are stained with $M A$. 1052. E and $F$ are stained with MA 1065 . Scale bar $=10 \mu \mathrm{m}$. 
Table 3. Immunoreactivity of monoclonal antibodies after chemical spliting of the epidermal basement membrane

\begin{tabular}{|c|c|c|c|}
\hline antibodies & type & $\begin{array}{l}\text { immunore } \\
\text { epithelial } \\
\text { layer }\end{array}$ & $\begin{array}{l}\text { ty } \\
\text { stromal } \\
\text { layer }\end{array}$ \\
\hline $1042 / 1043$ & $\mathrm{ma}$ & $+1-$ & $+t$ \\
\hline 1087 & $\mathrm{ma}$ & $+1-$ & ++ \\
\hline $4 \mathrm{E} 10$ & $\mathrm{ma}$ & + & $+1-$ \\
\hline $1052 / 1053$ & $\mathrm{ma}$ & - & ++ \\
\hline 1065 & $\mathrm{ma}$ & $++(p c)$ & - \\
\hline NP76 & $\mathrm{ma}$ & - & ++ \\
\hline type IV collagen & $\mathrm{pa}$ & $+1-$ & $+t$ \\
\hline laminin & pa & $+t$ & + \\
\hline
\end{tabular}

$\mathrm{ma}=$ monoclonal; $\mathrm{pa}=$ polyclonat antibodies; $t+=$ strong positiwe; $t=$ positive; $+1-=$ weakly positive; $-=$ negative; $\mathrm{pc}=$ pericellular

\subsubsection{Digestion of frozen sections}

Cryostat sections were pretreated with warious enzymes or reagents that cause elution of masking proteins or swelling of the tissue.

No differences were observed using hyaluronidase, acetic acid or urea/GuHCl. After protease treatment with pepsin, trypsin or pronase the immunoreactivity of $1042 / 1043$ was retained whereas the immunoreactivity with the other MA disappeared.

However, when bacterial collagenase (Closiridium histolyticum) was used, the immunoreactivity of 1042 and 1043 disappeared but the reactivity with the other MA remained, suggesting that these antibodies are directed against non-collagenous epitopes.

\subsection{Discussion}

BM all share the same basic structure, consisting of a lattice of type IV collagen and laminin (1). However, in view of the various functions of BM, cell or organ specific components may be expected to exist. The study of BM components, however, is difficult as they are linked in a complex and largely insoluble network with type IV collagen (2). Furthermore, presumed and as yet unknown specific components might be present in small amounts only, which might remain undetected or be lost during purification and chemical analysis (21). An alternative approach to establish the presence of specific com- 
ponents is the use of hybridoma technology. Immwination with intact BM might yield BM specific MA through screening of hybridoma supernatants by immunohistochemistry on the immunogen $(11,13)$. In the present study, which further extends our earlier observations (22), native BM from human amnion and glomeruli were used as immunogens, and the hybridoma supernatants were tested on cryostat sections of amnion and kidney. Three hybridomas with a BM resiricted staining pattern: 1052, 1053 and 1065 , obtained after immunization with amniotic BM were isolated. One hybridoma, which reacts with almost all BM, MA 1087, was obtained after immunization with glomerular BM. These MA were further analyzed by immunohistochemistry. The immunoreactivity patterns were compared with those of MA 1042 and 1043, which are directed against human type IV collagen (15). MA 1052 and 1053 showed no immunoreactivity on BM of mesodermal tissues, e.g. around blood vessels, muscle cells, fat cells or in the kidney, whereas almost all ectodermal and endodermal epithelial BM were stained with these MA. However, in the gastrointestinal tract heterogeneous epithelial BM staining was observed. Only BM in the superficial segments of the crypts and the top of the villi stained described previously (22). The heterogeneous staining pattern remained after digestion, elution or swelling of the tissue, suggesting that the heterogeneity is not due to masking of the epitope $(4,21,24)$. Furthermore, the epitopes of MA 1052 and 1053 were only detected in the BM adherent to the dermis after chemical splitting of the skin. These findings suggest that MA 1052 and 1053 detect a BM component with a basic structural role or a function in anchoring the basement membrane to the interstitial tissue, comparable to type VII collagen, the collagenous component of the anchoring fibers (9). Alternatively, components which exclusively localize in ecto- and endodermal epithelial BM, could be involved in mediating the barrier function of these epithelia. Isolation of these components and detailed chemical analysis might further elucidate their nature and function in the BM.

MA 1087 shows a pattern of immunoreactivity resembling that of MA 1042 and 1043, which are directed against type IV collagen. On chemically split skin MA 1042, 1043 and 1087 localize mainly in the BM segment adherent to the dermis, suggesting localization in the lamina densa. Our immunohistochemical results on chemically split skin are in agreement whth immuno-etectron microscopic observations, which localize laminin predominantly in the lamina lucida and type IV collagen predominantly in the lamina densa (2527). These results suggest that MA 1087 could be directed against type IV collagen. Contrary to the epitopes of MA 1042 and 1043, however, the 1087 epitope is insensitive for bacterial collagenase, which might indicate that this MA reacts with the non-collagenous globular part of type IV collagen, so called the NC1 domain (28-31).

MA 1065 reacts mainly with ectodermally derived epithelial BM and does not react with endodlermally derived epithelial BM. The only exception to this is the BM of the oesophageal and tracheal epithelial lining. Furthermore pericellular staining occurs around basal cells of the epidermis and cornea. In chemically split skin MA 1065 shows immunoreactivity only in the epidermal segment. The pericellular localization suggests that the antigen detected by MA 1065 might be involved in intercellular adhesion and/or adhesion of the basal cells to the basement membrane. 
In conclusion, the newly produced set of MA to BM confirm that BM in various anatomic sites have unique characteristics. The use of intact $\mathrm{BM}$ as immunogen in combination with the hybridoma technology for the production of MA and immunohistochemistry for MA selection is a useful approach to study new BM components. This approach may be used to further unravel the BM structure.

\subsection{References}

1. Martine 2 -Hernandez A, Amenta PS. The basenen membrane in pathology Lab hwesh $48,656,1983$

2. Bosnan, F, Hawenith M, Cleutjens J: Basement membranes in cancer. Ultrastruct Pathod $\$, 291,1985$

3. Fine JD: Cicatricial pemphigotd, bullous pemphigoid and epidermolysis bullosa acquisita antigens Dirferences in organ and species specificities and localization in chemically-separated human skin of three basement membrase antigens. Collagen Rel Res 5, 369, 1985

4. Wieslander J, Langeveld J, Butkowski $R$, Jodlowski M, Noelken $M$, Hudson BG: Physical and mmunochemical studies of the globular domain of type IV collagen. J Biol Chem 260, 8564, 1985

5. Damjanow I: Biology of disease: Lectin cytochemistry and histochenistry. Lab Invest 57, 5, 1987

6. Lee M-C, Damjanov I: Lectin histochemistry of human placenta. Differentiation $28,123,1984$

7. Wewer U, Albrechtsen R, Manthorpe M, Varon S, Engrall E, Ruoslahti E: Human laminin isolated in a nearly intact, biologically active form from placenta by limited proteolysis. J Biol Chem 258, 12654, 1983

8. Leu $\mathbb{F}_{\text {, Engvall }} \mathbb{E}$, Damjanov 1: Heterogeneity of basement membranes of the human genilourinary tract reveated by sequential immunotuorescence staing whth monoclonal antibodics to laminin. J Histochen Cylochem $34,483,1986$

9. Sakkai L, Keene D, Morris N, Burgeson R: Type VIl collagen is a major structural component of anchering librils. J Cell Biol 103,1577, 1986

10. Keene DR, Sakai LY, Lunstrum GP, Morris NP, Burgeson RE; Type VIl collitgen for nus ant exlended ne: work of anchoring fibrils. J Cell biol 104, 611, 1987

11. Hessle H, Sakai L, Hollister D, Burgeson R, Engvall E: Basement membrane diwersity deteded by mono. conal antibodies. Differentiation $26,49,1984$

12. Verrando P, Ortonne J-P, Pautrat $G, H$ si B-L, Yeh CJ: Identification of a 37 kilodalton protein at the epider * mal basement membrane by an antiser un to htman amnion. J Invest Dermatol $87,190,1986$

13. Hinsch K. D, Hansen D, Zimmermann A, Brucharusen $\%$. F: Production and inmunohistochenical characterization of monoclonal antibodies directed against renal basenent membrames of rats. Histof Histopath 3 , 325,1988

14. Liot a LA, Lee CW, Morakis DJ: New method for preparing large surfaces of int act human basement membrane for tumor invasion studies. Cancer Letters $11,141,1980$

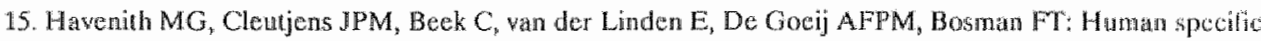
anti-type IV collagen monoclonal antibodies, characterization and immunohistochemical application. Histochernistry $87,123,1987$

16. Langeveld JPM, Veerkamp HH: Chemical characterizat ion of glomerular and tubular basement membrances of various mammalian species. Comp Biochem Physiol 688, 31, 1981

17. Ohno M, Martinez-Hernandez $\mathrm{A}$, Ohno $\mathrm{N}$, Kefalides NA: Isolation of laminin from human placental bastmeml membranes, ammion, chorion and chorionic microvessels. Biochem Biophys Res Cormm $112,10 \% 1$, 1983

18. Kohler $\mathrm{G}$, Milstein $\mathrm{C}$. Continuous cutures of fused cells secreting antbody of predefined specificily. Nat Iure, $256,495,1975$ 
19. Fine $J \mathrm{D}$, Redmar DA, Goodwain AL: Sequence of reconstitution of seven basement membrane components following split-thickness wound induction hin prinate skin. Arch Dermatol 123, 1174, 1987

20. Clevtjers JPM, Havenith MG, Wallinga M, Bosman FT: Absence of type IV collagen in corneal epithelial basement membrane. Submitted. This thesis chapter 4 .

21. Fitch JM, Linsenmayer TF: Monoclonal antibody analysis of ocular basement membranes during dewelopment. Dey Brol $95,137,1983$

22. Cletijens JPM, Hawenith M, Beek C, Vallinga M, Bosman FT: Basement membrane heterogeneity detected by monoclonal antibodies. Acta Histochemica (in press).

23. Linsenmayer TF, Fitch JM, schmid T, Zak, NB, Gibney E, Sanderson RD, Mayne R: Monoclonal antibodies against chick type $V$ collagen: production, specificity, and their use for immunocytological localization in embryonic cornea and other organs. J Cell Biol $96,124,1983$

24. Bronckers AlJJ, Gay S, Lyaruu DM, Gay R, Miller EJ: Localization of type V collagen with monoclonal antibodies in deweloping dental and peridental tissues of the rat and the hamster. Collagen Rel Res 6,1 , 1986

25. Courtoy PJ, Timpl R, Farquhar MG: Comparative distribution of laminin, type IV collagen, and fibronectin in the rat glomerulus. J Histochem Cytochem 30, 874, 1982

26. Farquhar MG: The glomerular basement membrane. A selective macromolecular filter. In: Cell Biology of extraccllular matrix. Hay ED, ed. Plenum Press, New York 335, 1981

27. Foidart IM, Bere EW, Yaar M, Renuard SI, Gullino M, Martin GR, Katz SI: Distribution and immunoelectron microscopic localization of laminin, a noncollagemous basement membrane glycoprotein. Lab Invest $42,336,1.980$

28. Kleppel MM, Michael AF, Fish Ar: Comparison of mon-collagenous type IV collagen in the human glomerulus and EHS tumor. Biochem Biophys Acta 883, 178, 1986

29. Wieslander J, Bygren P, Heinegard D: Isolation of the specific glomerular basement menbrane antigen involwed in Goodpasture syndrome. Proc Natl Acad Sci USA 81, 1544, 1984

30. Wieslandler J, Barr JF, Butkowski RJ, Edwards SH, Bygrem P, Heinegard D, Hudson BG: Goodpasture antigen of the glomerular basement membrane: localization to noncollagenous regions of type IV collagen. Immunology 81, $3838,1.984$

31. Butkowski RJ, Langeweld JPM., Wieslander J, IFamilton J, Hudson BG: Localization of the Goodpasture epitope to a novel chain of basement membrane collagen. J Biol Chem 262,7874, 1987

32. Goodpasture EW: The significance of certain pulmonary lesions in relation to the etiology of influe ma. Am J Med Sci $158,864,1919$ 


\section{Chapter 3}

Biochemical and immunohistochemical characterization of monoclonal antibodies against the NC1 globular domain of type IV collagen*

* Cleuljens JPM, Beek C, wan Breda Vriesmán PJC, Bosman FT.

Submitted for publication. 


\section{1 introduction}

The basement membrane (BM) is a specific compartment of the extracellular matrix, which is in close juxtaposition with epithelial and endothelial cells and tightly surrounds some mesenchymal cells e.g. fat, muscle and Schwann cells (1).

The major structural component of the BM is type IV collagen $(2,3)$ of which the triple helix is composed of at least two different $\alpha$ chains ( $\alpha$ (IV) and $\alpha 2$ (IV)). The amino-terminus of the triple-helical monomer contains a disulfide-rich domain which combines with three other amino-terminal ends to form a tetramer (4-6). The carboxy-terminus of the molecule contains a large globular domain, which binds to the globular domain of another type IV collagen molecule, partly by disulfide bonds and partly by covalent cross-linking, to form the NC1 (non-collagenous) domain (7). The NC1 domain can be released from the triple helix by digestion with bacterial collagenase. When isolated from this digest the NCI domain appears to be a hexameric structure with a molecular weight of approximately 170 $\mathrm{kD}$, which can be separated into monomers and dimers by incubation with $6 \mathrm{M}$ guanidi= nium hydrochloride, urea, dilute acetic acid or sodium dodecyl sulphate (8).

The NCl domain has received considerable attention in connection with the Goodpasture syndrome (9). Goodpasture syndrome is clinically characterized by pulmonary hemorrhages followed by renal insufficiency, and immunohistochemically characterized by diffuse linear staining of pulmonary and glomerular BM. This linear staining is caused by binding of $\mathrm{IgG}$ autoantibodies to the BM. Although the epitopes of the Goodpasture autoantibodies can be found in all BM, mainly the kidney and the lung are affected. Increased reactivity with Goodpasture autoantibodies has been observed with denaturated BM antigens, which suggests that normally cryptic antigenic determinants in human kidney and lung can be exposed and induce autoantibody formation, resulting in the Goodpasture syndrome. Recent studies have shown that the Goodpasture antigen is sequestered inside the hexameric structure of the NC1 domain of type IV collagen (8). The antigen can be detected by inmunoblotting, using autoantibodies from Goodpasture patients, which react with monomeric and dimeric bands of hexamers released from type IV collagen by collagenase digestion.

We have recently raised BM reactive monoclonal antibodies (MA) through immunization with amniotic and glomerular BM (10). By immunohistochemistry some MA (1087) showed uniform linear staining of all BM, whereas others (1052 and 1053) showed heterogeneous $\mathrm{BM}$ staining. The latter $\mathrm{MA}$ reacted only with $\mathrm{BM}$ in ecto- and endodermal organs, and in the gastro-intestinal tract only with superficial BM of crypts and villi. The epitopes of these MA appeared to be insensitive to bacterial collagenase. This finding led us to compare the immunoreactivity of MA 1052,1053 and 1087 with sera from patients with Goodpasture syndrome and anti-glomerular BM (anti-GBM) glomerulonephritis. Pa* tients with anti-GBM nephritis resemble those with Goodpasture syndrome in having $\lg G$ autoantibodies bound to the glomerular BM. In contrast to the Goodpasture syndrome, 
the pulmonary hemorrhages in anti-GBM glomerulonephritis are caused by wolume overload secondary to renal insufficiency. In the present report we describe the biochemical and immunohistochemical properties of these MA.

\subsection{Materials and methods}

\subsubsection{Isolation of the basement membranes}

Human amniotic membranes, obtained directly after delivery, were separated into chorion and amnion. The amniotic membrane was washed in phosphate buffered saline pH 7.4 and mechanically treated with a rubber policeman to remove blood and adhering chorionic membranes. For immunization the membranes were denuded by chemical and mechanical treatment as described by Liotta et al. (11). In short, amnion was washed one hour in distilled water with $2 \mathrm{mM} \mathrm{N}$-ethyl maleimide (NEM), extracted one hour with $1 \mathrm{M} \mathrm{NaCl}, 20$ mM EDTA, 2 mM NEM and finally one hour with $4 \%$ de-oxycholate. After each step the membranes were mechanically treated with a rubber policeman to remove amniotic epithelial cells and most of the interstitial stroma.

Human glomerular BM extracts were kindly provided by Dr. B. van den Heuvel (Nijmegen). These were prepared according to the procedure described by Langeveld et al. (12). In short human kidney cortex was sequentially sieved on several mesh sizes. Glomeruli were obtained at mesh sizes between 90 and $125 \mu \mathrm{m}$. The glomeruli were lysed in $0.1 \% \mathrm{NaN}_{3}$ and $1 \mathrm{mM} \mathrm{EDTA}$, centrifuged and subsequently incubated $5 \mathrm{~h}$ with $4 \%$ sodium de-oxycholate, treated 2.5 In with deoxyribonuclease (59 Kunitz units/mly washed with distilled water and lyophilized.

\subsubsection{Monoclonal antibodies}

Monoclonal antibodies were obtained after immunization with native amniotic or glomerular BM, ats extensively described in chapter 2 (10). Antibody production by hybridomas was detected immunohistochemically on frozen sections of the immunogens. Productive clones (1052, 1053 and 1087) were recloned until monoclonal by limiting dilution. MA to human type IV collagen (1042 and 1043), isolated from human placenta by pepsin digestion (13) were obtained and described extensively in chapter 9.4.

\subsubsection{Immunohistochemistry}

Frozen sections of human tissues were air-dried and fixed in acetone. The sections were washed with PBS and incubated with hybridoma culture supernatant or using sera of patients with autoantibodies to glomerular BM. After washing the sections were incubated with peroxidase labeled conjugate and peroxidase activity was visualized by incubation with diaminobenzidine as described in chapter 9.2. 


\subsubsection{Pretreatment of tissue sections}

To urinask hidden epitopes, frozen sections $(4 \mu \mathrm{m})$ of human kidney cortex were pretreated during 5 min at different temperatures $\left(\mathrm{RT}, 50^{\circ} \mathrm{C}\right.$ or $\left.100^{\circ} \mathrm{C}\right)$ with $6 \mathrm{M}$ urea, $6 \mathrm{M}$ guanidinumbydrochloride or acetic acid $\mathrm{pH} 3.0(8)$. Frozen sections of human amnion and human kidney cortex were digested with $0.5 \mathrm{mg} / \mathrm{ml}$ bacterial collagenase in $50 \mathrm{mM}$ Tris, $0.36 \mathrm{mM} \mathrm{CaCl}(\mathrm{pH} 7.6)$ at $37^{\circ} \mathrm{C}$ for $30 \mathrm{~min}, 1 \mathrm{hr}, 2 \mathrm{hr}, 4 \mathrm{hr}$ and overnight and subsequently stained as described under immunohistochemistry (chapter 9.2), the digest however was spotted onto nitrocellulose, dried and treated 3 times 10 min with PBS, $0.1 \%$ bovine serum albumin and subsequently stained with the monoclonal antibodies as described under immunohistochemistry (chapter 9.2).

\subsubsection{Pattents and sera}

The patients derived from the Regional Working Party on Renal Diseases and included one patient with Goodpasture syndrome and 5 patients with rapidly progressive glomerulonephritis caused by anti-GBM antibodies. The diagnosis anti-GBM glomerulonephritis was based on:

a. linear deposition of $\operatorname{IgG}$ along the GBM with diffuse extra capillary crescent formation. b. the presence of anti-GBM antibodies in the serum by radio-immuno-assay (RIA) and by enzyme-linked-immunosorbent-assay (ELISA) (25-27).

c. the absence of pulmonary hemorrhages prior to irreversible renal insufficiency.

The patient with the Goodpasture syndrome developed pulmonary hemorrhages followed by renal insufficiency due to diffuse crescentic glomerulonephritis after one month and associated with linear deposition of IgG autoantibodies alongside the GBM. This patient showed no anti-GBM antibodies by RIA and ELISA in the serum. Patient data, data on renal immunopathology and patient serums were kindly provided by Prof. van Breda Vriesman, Dept. of Immunology, University of Maastricht.

\subsubsection{Collagenase digestion}

Collagenase digestion was performed as described by Kleppel et al. (14). Human amniotic membranes or human kidney cortex were washed with phosphate buffered saline (PBS) pH 7.4, $1 \mathrm{mM}$ phenylmethylsulfonylfluoride (PMSF), $2 \mathrm{mM}$ n-ethyl maleïmide ( $N E M$ ), and subsequently the tissue was minced using a Ultraturrax-grinder. The tissue fragments were centrifuged $10,000 \mathrm{~g}$ at $4^{\circ} \mathrm{C}$ and extracted during $24 \mathrm{~h}, 4^{\circ} \mathrm{C}$ with PBS, $0.5 \mathrm{M} \mathrm{NaCl}$, PMSF, NEM pH 7.4, centrifuged and treated 48 hr with $3 \%$ acetic acid, PMSF, NEM, 10 $\mu \mathrm{g} / \mathrm{ml}$ pepstatin $\mathrm{A}$ and centrifuged. The pellet was freeze dried and digested $24 \mathrm{~h}, 37^{\circ} \mathrm{C}$ with $10 \mathrm{U} / \mathrm{mg}$ collagenase (type VII collagenase, Clostridium histolyticum; Sigma) diluted in $50 \mathrm{mM}$ Tris ( $\mathrm{pH} 7.6$ ), $0.2 \mathrm{M} \mathrm{NaCl}, 2 \mathrm{mM} \mathrm{CaCl}$. The digest was centrifuged at $16,000 \mathrm{~g}$ for $30 \mathrm{~min}$ and the supernatant was dialyzed against water and subsequently freeze-dried. 


\subsubsection{Electrophoresis}

Isolated proteins were run on $10 \%$ SDS polyacrylamide gels (15), and subsequently electroblotted to nitrocellulose paper (16) as described in chapter 9.5. Reductive cleavage was performed by incubating $360 \mu$ l of a solution of amnion collagenase digest $(10 \mathrm{mg} / \mathrm{ml})$ in 0.1 $\mathrm{M}$ Tris, $5 \mathrm{mM}$ EDTA pH, 8.2 with $40 \mu \mathrm{l} 0.1 \mathrm{M}$ dithiothreithol; dissolved in the same buffer. After 1,3 and $6 \mathrm{~h}$ incubation at $37^{\circ} \mathrm{C}, 20 \mu \mathrm{l}$ was taken out of the solution and the reduction was stopped by adding $20 \mu 50 \mathrm{mMN}$-ethylmaleimide in $0.1 \mathrm{M}$ Tris pH 7.4 (24). Prior to electrophoresis SDS was added to an endconcentration of $1 \%(w / v)$ and the reaction mixture was heated for $5 \mathrm{~min}$ at $95^{\circ} \mathrm{C}$.

For isoelectric focusing, samples were run on a $5 \%$ polyacrylamide gel ( $3 \%$ cross-linking), containing $10 \%$ glycerol and $6 \%$ ampholytes $(0.33 \%(\mathrm{v} / \mathrm{V})$ ampholytes $\mathrm{pH} 4-6,0.33 \%(\mathrm{v} / \mathrm{v})$ ampholytes $\mathrm{pH} 5-7,0.66 \%(\mathrm{v} / \mathrm{v})$ ampholytes $\mathrm{pH} 9 \mathrm{~m} 11,4.66 \%(\mathrm{v} / \mathrm{v})$ ampholytes $\mathrm{pH} 3.5-10)$. The collagenase digest was run $3.5 \mathrm{~h}$ at $4{ }^{\circ} \mathrm{C}$ with $12 \mathrm{~W}$ constant power, and one lane with marker proteins (Serva, Heidelberg) as a reference. To check the pH gradient, $0.5 \mathrm{~cm}$ pieces were cut out the gel, incubated overnight with distilled water and subsequently measured. The focused proteins were blotted semidry to nitrocellulose paper.

\subsection{Results}

\subsubsection{Immunohistochemistry}

The MA obtained by immunization with amniotic membranes (1052 and 1053 ) showed a heterogeneous staining pattern, reacting exclusively with BM of epidermis and epidermal adnexa, such as sebaceous and sweat glands and hair follicles. Furthermore BM of glandular epithelium of breast and prostate "squamous epithelium of the tongue, oropharynx oesophagus, and vagina, and ciliated epithelia of the trachea and bronchus as well as alveolar BM in the lung were stained. In the lung no reactivity occurred with the endothelial basement membrane. In the gastrointestinal tract epithelial BM of the superficial crypt (colon) or villous (small intestine) structures was observed, whereas deeper in the mucosa $\mathrm{BM}$ reactivity was absent. No reactivity was obtained with renal or vascular BM or with BM of fat-, muscle-, or Schwann cells.

Immunoreactivity could not be induced by tissue pretreatment with denaturating agents, such as guanidiniumhydrochloride, urea, SDS or acetic acid, nor by digestion with bacterial collagenase, whereas the dot spotted collagenase digest stained with MA 1052, 1053 and 1087.

MA 1087, obtained by immunization with human glomerular BM, showed staining of all BM except the central epithelial BM of the cornea. Staining of cryostat sections from a renal biopsy of a patient with Alport's syndrome with anti type IV collagen MA (1042 and 
$1043)$ and MA 1087, showed distinctly less intense immunoreactivity with 1087 than with 1042 and 1043 . The staining intensity was especially less in the glomerular and tubular BM, whereas homogeneous staining of the endothelial BM was obtained with all MA.

On tissue sections of human amnion the immunoreactivity of MA 1052, 1053 and 1087 was retained after treatment with bacterial collagenase for 30 min until 4 hr. However, similar pretreatment of sections from kidney cortex showed that MA 1087 still reacted with the BMt of this tissue, whereas with MA 1052 and 1053 even after severe digestion no immunoreactivity could be obserwed. After overnght collagenase digestion no immunoreactivity could be observed with any of the tissues and antibodies used due to disintegration of the tissue. However, when the digest of the sections was spotted onto nitroceliulose filters clear immunoreactivity could be observed with all MA on both tissues. The staining intensity diminished after overnight incubation, perhaps due to severe cleavage of the isolated hexamer by bacterial collagenase or by the effect of other enzymatic impurities in the digestion mixture. The epitopes of all three MA lost immunoreactivity by treatment with proteases such as pepsin, trypsin and pronase.

\subsubsection{Immunochemistry}

In an attempt to isolate the epitopes of the MA, amniotic membranes and kidney cortex were digested with collagenase, which releases the $\mathrm{NCL}$ domains. The reactivity of the MA was tested after electrophoresis and immunoblotting of the digested protein. MA 1087, 1052 and 1053 showed identical patterns of reactivity after electrophoresis under unreduced conditions with amnion collagenase digest (Fig 1). Three major immunoreactive bands were found with a molecular weight of about 48,42 and $23 \mathrm{kD}$ respectively. In addition the collagenase digest of amnion showed two minor bands with a molecular weight of 95 and $86 \mathrm{kD}$. The digest of kidney cortex showed another low MW band of about $26 \mathrm{kD}$ (Fig 2). The immunoreactivity with the 48 and $42 \mathrm{kD}$ bands was observed with all three monoclonal antibodies and with both tissues. Under reducing conditions none of the above mentioned bands could be detected but one new band of $32 \mathrm{kD}$ occurred, which stained witl all three MA (Fig 3). A shift to higher molecular weight bands was observed after incomplete reduction. The collagenase digest from the amniotic BM was electrophoresed, blotted and stained with sera from patients with anti-GBM glomerulonephritis and Goodpasture syndrome. The staining pattern varied somewhat dependent on the antibody liter of the patient sera, but the sera of patients with anti-GBM glomerulonephritis (tane $1,3-6$ ) sllowed reaction with the 48,42 and $23 \mathrm{kD}$ bands, dependant on the dilution of the serum (Fig 4). The patient with Goodpasture syndrome did not show immunoreactivity with these bands. Two additional major bands were detected, with a molecular weight of about 36 and $20 \mathrm{kD}$, and also two minor bands with molecular weights between 80 and $98 \mathrm{kD}$.

After isoelectric focusing, the focused proteins were subsequently blotted onto nitrocellulose filters. All MA stained two bands intensely, with isoelectric points at pH 8.4 and 7.8 , and furthermore a weaker staining band was observed with an isoelectric point of $\mathrm{pH} 7.6$ (Fig 5 ). 

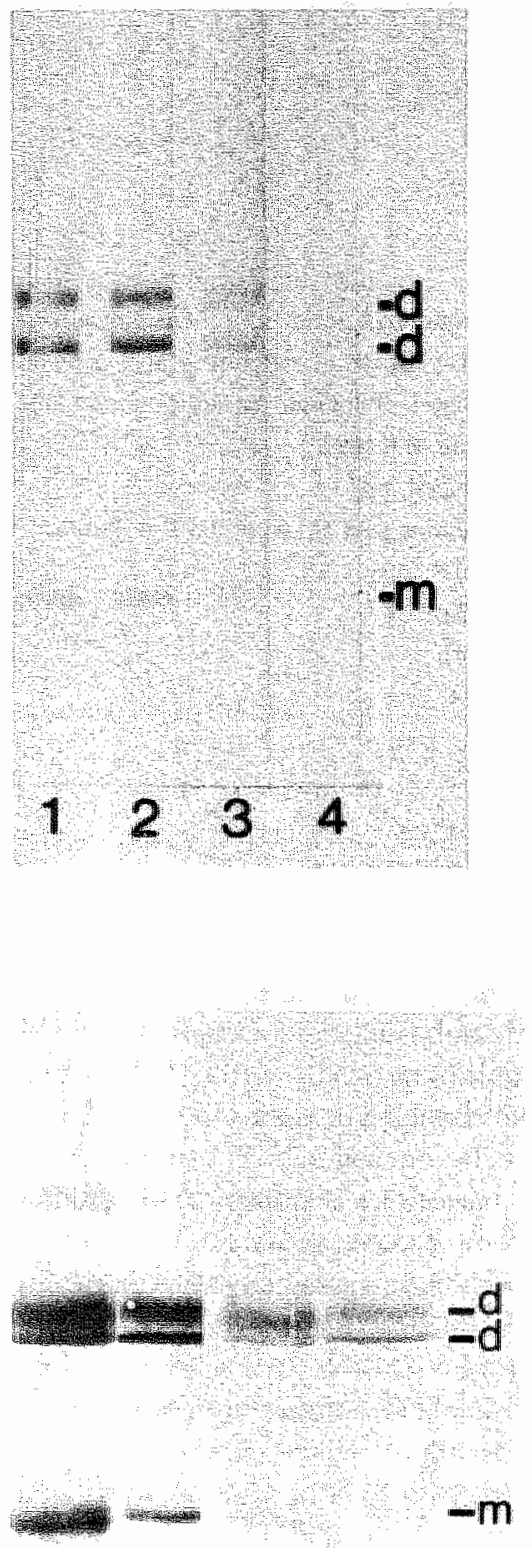

$\begin{array}{lllll}1 & 2 & 3 & 4\end{array}$
Figure 1. Immonoblof after 10\% 505 polyacrytamide gelelectrophorasis of unreduced colligenaso digusical human amniotic membranes.

Lane 1: immunoreactivity obtained with MA 108 \%,

Lane 2: immunoreactivity obtained with MA 1052,

Lane 3: immunoreactivity obtained with MA 1053,

Lane 4: negative control.

$\mathrm{D}=$ dimeric bands with a MW of 48 and $42 \mathrm{kD}$,

$\mathrm{M}=$ monomeric band with a $\mathrm{MW}$ of $23 \mathrm{kD}$.

Figure 2. Immunoblot after $10 \%$ SDS-polyacrylamide gclelectrophoresis of unreduced collagenase digest of; humatid kidncy cortex (lane 1 and 3 ). collagenase diges: of human anniotic membranes (lanc 2 and 4$)$.

The blots were respectively stained with:

MA 1087 (lane 1 and 2).

MA 1052 (lane 3 and 4). 

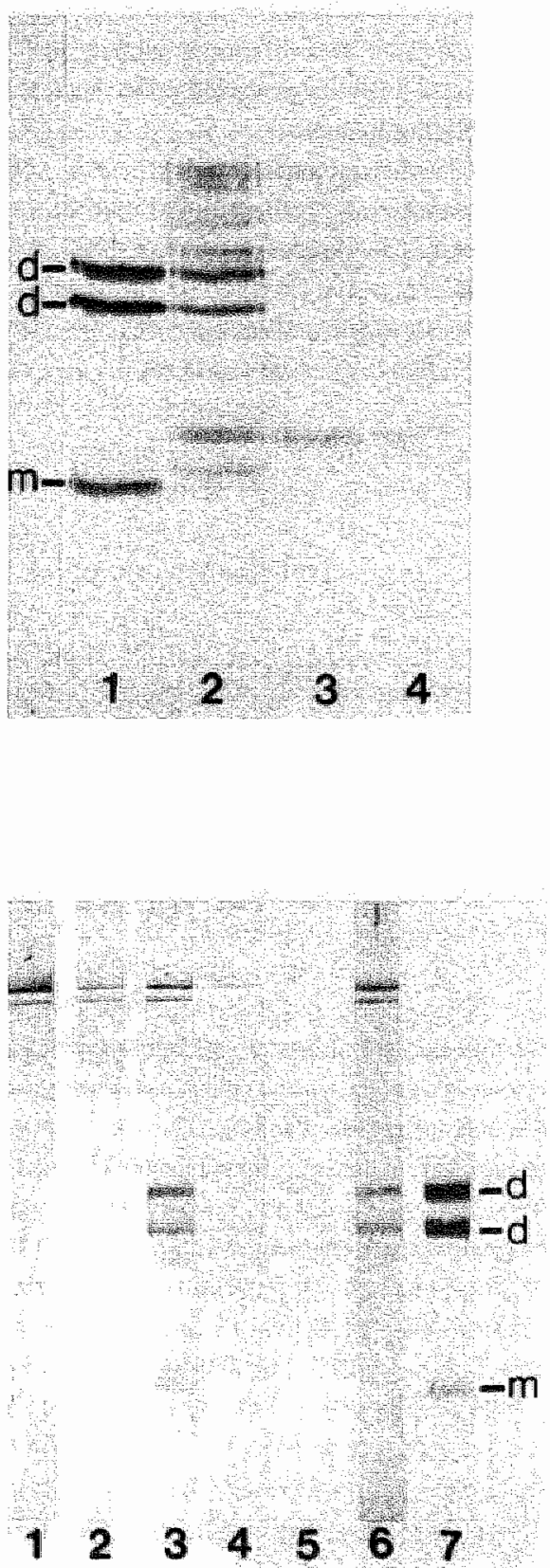

Figure 3. Immanoblot after $10 \%$ SDS-polyacrylamide grelectrophoresis of unreduced and reducod collagenase digest of human amniotic membranes and stained whith MA 1087.

Lane 1: unreduced,

Lane 24: reduction with $0.1 \mathrm{M}$ dithiothreithol ror: 1 hour (lane 2),

3 hours (lane 3 ),

6 hours (lane 4).
Figure 4. Immunoblot after $10 \%$ SDS-polyacrylamide gelelectrophoresis of unreduced collagenctse digest from amniotic nembranes stained whth:

patient sera with anti-GBM glomerulonephritis (lane 1 and $3-6)$

patient serum with Goodpasture syndrome (lane 2), MA 1087 (tane 7$)$. 


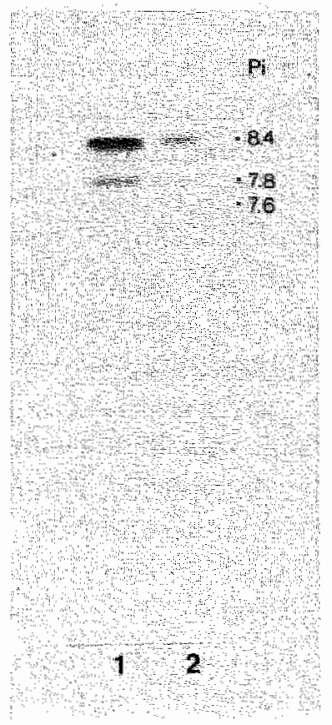

Figure 5. Immunoblot after isoelectric focusing in a 5\% gel of collagenase digested amniotic nembranes. Lane $1=$ stained with MA 1087 , Lane 2 = stained with MA 1052.

\subsection{Discussion}

At the carboxyterminal NC1-domains of two type IV collagen molecules these molecules are bound together (7). NCl domains can be isolated from BM by bacterial collagenase digestion (14). Under these conditions the NC1-domain appears as a hexameric structure of which the monomers are bound together partly by disulfide bonds and partly by covalent cross-linking (7). The hexamer dissociates into dimers and monomers under acidic or denaturating conditions.

The NC1-domain has recently gained considerable attention through its association with the so called Goodpasture antigen (28). The Goodpasture syndrome is characterized by pulmonary hemorrhages and circulating autoantibodies, reactiwe with pulmonary alveolar and glomerular BM. With Goodpasture patient sera only the glomerular BM stains, unless tissues are pretreated with denaturating or acidic agents. The Goodpasture epitope is thought to reside inside the hexameric structure of the globular domain of type IV collagen, and denaturation of this structure is needed to expose the epitope $(8,17)$. Recently the reactivity of Goodpasture sera with a novel $\alpha 3$ chain of type IV collagen $(18,19)$ was reported. We have isolated three MA against human BM: MA 1087 reacting with almost all $B M$ and MA 1052 and 1053 reacting uniformlly with BM of ectodermal, and heterogeneously with BM of endodermal and not at all with BM of mesodermal origin (10). The epitopes of MA 1052, 1053 and 1087 are all susceptible to protease treatment but resistant to bacterial collagenase. 
Treatment of tissue sections with denaturating or acidic agents or collagenase digestion did not induce immunoreactivity with MA 1052 and 1053 in mesodermal BM, whereas immunoreactivity with all three $M A$ could be detected after dot spotting of this tissue section digest. This finding suggests that in order to expose the epitopes of MA 1052 and 1053 in mesodermal $\mathrm{BM}_{4}$ these have to be released from the triple helical part of type IV collagen. Staining of a kidney section from a patient with Alports familial nephritis showed less immunoreactivity of MA 1087 in glomerular and tubular BM than with MA against the triple helical part of type IV collagen (1042 and 1043) as was described for Goodpasture patient sera by Kashtan et al. (20). These findings suggest that at least the epitope of MA 1087 could be associated with the Goodpasture antigen.

In order to resolve this matter we performed a series of immunoblotting experiments with our MA as well as with sera from patients with autoimmune glomerulonephritis. After SDS-gelelectroplhoresis all MA showed reactivity with bands with molecular weights of 48 , 42 and $23 \mathrm{kD}$, which resemble the D2* dimers and $\mathrm{M}^{*}$ monomers of the NC1 domain of type IV collagen $(21-23,29)$. Staining of higher molecular weight bands $(80-98 \mathrm{kD})$ can be explained as undissociated tetramers of the NC1 domain. Using sera with autoantibodies to glomerular BM we also observed these dimers ( 48 and $42 \mathrm{kD}$ and sometimes also the monomer $(23 \mathrm{kD}$ ). Some patient sera stained additional bands ( 36 and $20 \mathrm{kD}$ ), which suggests that also other BM components can become target in this autoimmune disease (8).

Although on immunoblots MA 1052, 1053 and 1087 showed the same immunoreactivity pattern, different patterns were noted in immunohistochemistry experiments. MA 1052 and 1053 only stained a limited range of epithelial BM whereas 1087 stained all BM, except the central epithelial corneal BM. Even collagenase treatment did not induce immunoreactivity with MA 1052 and 1053 in the kidney, whereas the dot spotted digest or electrophoresed collagenase digest showed reactivity with MA 1052, 1053 and 1087. This discrepancy points towards an interesting phenomenon. Although the NC1-domain epitopes occur in BM of kidney and amnion, in the kidney the supramolecular structure of the BM in situ masks the epitopes of MA. 1052 and 1053. This finding suggests that in different BM variations in assembly of the same basic BM components exists. This could be due to heterogeneous combinations of the 3 to 4 different atchains of type IV collagen (19). Another explanation could be that both epitopes are present, but in some organs the epitopes of MA 1052 and 1053 are masked by other BM components attached to type IV collagen. In conclusion, our three monoclonal anti BM-antibodies identify epitopes in the NCl-donain which reveal characteristic heterogeneity in the supramolecular assembly of type IV collagen in the BM.

\subsection{Reterences}

1. Vracko R: The role of basal lamina in maintenance of ordlerly tissue structure. In: New trends in basement nembrane research. Ed. Kinh, Schoene, Timpl 1, 1982

2. Kefalides NA, Alper R, Clark CC: Biochemistry and metabolism of basement membranes. Int Rev Cytol $61,167,1979$ 


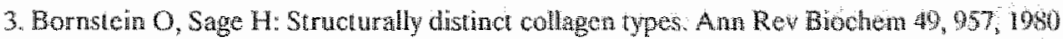

4. Timpl $R$, Wiedemann $H$, Van Delden $V$, Furthmay $H$, Kuhn $K$ : A network model for the argantration of typo IV collagen molecules in basement membranes. Eur J Biochen 120, 203, 1981

5. Kün K, Wiedemann R, Tumpl R, Ristelli, Dieringer $H$, Voss T, Glanvile R W: Macromolecular structure of basement membrane collagens identification of $7-S$ collagen as a cross-linking domatim of lype IV collagen. FEBS Lett 125, 123, 1981

6. Duncan KG, Fessler LI, Băchinger HP, Fessler $₫ H$ : Procollagen IV. Association to tetramers. J Biol Chem $258,5869,1983$

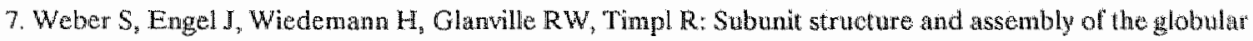
domain of basement me mbrane collagen lype IV. Eur J Biochem 139, 401, 1984

8. Wieslander J, Langeveld J, Butkowski $R$, Jodlowski M, Noelken M, Hudson BG: Physical and immunochemical sudies of the globular domain of type IV collagen. Cryptic properties of the Goodpasture antigen. I Biol Chem 260, 8564,1985

9. Goodpasture EW: The significance of certain pulmonary lesions in relation to the etiology of influenza. Am J Med Sci $158,864,1919$

10. Cleutjens JPM, Havenith MG, Beek C, Vallinga M, Bosman FT: Basement membrane heterogencity detected by monoclonal antibodies. Acta Histochemica (in press)

11. Liotta LA, Lee CW, Morakis DJ: New method for preparing large surfaces of intact human basement membrane for tumor inwasion studies. Cancer letters 11, 141, 1980

12. Langeveld JPM, Veerkamp HH: Che enical characterization of glomerular and tubular basement memhraness of various mammallan species. Comp Biochem Physiol 688, 31, 1981

13. Havenith MG, Cleujens JPM, Beek $C_{n}$ van der Linden E, De Goey AFPM, Bosman FT: Human specific anti type IV collagen monoclonal antibodies, characterization and immunohistoche mical application. HisLachemistry 87, 123, 1987

14. Kleppel MM, Michael AF, Fish AJ: Comparison of non*colagenous type IV collagen in the human glonerulus and EHS tumor. Biochem Biophys Acta 883, 178, 1986

15. Laemnli UK: Cleavage of structural proteins during the assembly of the head of the bacteriophage T4. Nature $227,680,1970$

16. Towbin H, Staehelin Th, Gordon J: Electrophoretic transler of proteins from polyacrylamide gels to nit rocellt:lose sheets: procedure and soms applications. Biochem 76, 4350, 1979

17. Yoshioka K, Kleppel M, Fish AJ: Analysis of nephritogenic antigens in human glonerular basement menzbrane by wor-dimensional gel electrophoresis. J Immunol 134, 3831, 1985

18. Butkowski R., Langeveld JPM, Wieslander J, Hamilton J, Hudson BG: Localization of the Goodpasture cpirope to a novel chair of basement membrane collagen. J Biol Chem 262,7874, 19887

19. Saus J, Wieslander J, Langeveld JPM, Ounones $\mathrm{S}$, Hudson BG: Identilcation of the Goodpast ure andigen as the $(X)$ (WW) chain of collagen IV.J Biol Chem 263, 13374, 1988

20. Kashtan C, Fish AJ, Kleppel M, Yoshoka K, Michael AF: Nephritogenic antigen determinants in epidermal and renal basemen membranes of kindrads with Aportype famalial nephitis. I Clin Inwes. 78,1035, 1986

21. Wicslander J, Barr JF, Butkowski RJ, Edwards SH, Bygren F, Heincgard D, Hudson BG: Goudpasturc antigen of the gomerular basement membran localioation to noneollagenous regions of rype IV collagen. Inmunology $81,3838,1984$

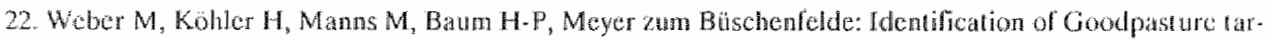
get antigens in basement membranes of humanglomertili, lang and placenta Clin Exp Lnmunol $677_{\mathrm{z}} 262_{n}$ 1987 
23. Butkowsi RJ; Wieslander J; Wisdom BI, Barr JF, Woelken ME, Hodwon BG: Properties of the globular doman of type IV collagen and its relationship to the Goodpasture antigen. J Biol Chem $260,3739,1985$

24. Weber \&, Duk $\mathrm{R}$, Timpl $\mathrm{R}$, Fessler JH, Engel I: Reductive cleavage and relormation of the anterchain and intrachailin diswlide bonds in the globular hexameric donain $\mathrm{NCl}$ involved in network assenbly of buscment membrane collagen (type IV). Eur I Biochem $175,22 \%, 1988$

25. Wieslander $J$, Bygren $\mathbb{P}$; Heincgard D: Antibasement menbrane antibody Immunoenzymatic assay and specificity of ancibodies. Scand J Clin Lab Invest $41,763,1981$

26. Mahieu P, Lamben PH, Miescher PA: Detection of antiglomerular basement mumbrane inlibodics by at radicimnunologicall technique. Kidney Int 16, 93, 1979 (Abstract)

27. Wiston CH; Radioimmunoassay for ani-glomerular basement membrane andibodics. In: Manual of cliacal immunology. Rose NR, Friedman H, eds. American Society for Microbiology, Washinglon DC. 2 nd cd. 376,1080

28. Fish AJ, Lockwood MC, Wong M, Price RG: Detection of Goodpasture antigen in fractions preparcd from collagenase digests of human glomeralar basement membrane. Clin Exp Immunol 55, 58, 1984

29. Kleppel MM, Michael AF, Fish AJ: Antibody specificity of thuman glomerular basement membrane eype IV collager MC1 subunits. I Biol Chem 261, 16547, 1986 


\section{Chapter 4}

\section{Absence of type IV collagen in corneal epithelial basement membrane*}

*Cleutjens 』PM, Havenith MG, Vallinga M, Bosman FT.

Submitted for publication. 


\section{1 introduction}

Basement membranes (BM) are ubiquitous extracellular matrix structures which connect epithelial cells with the adjacent connective tissue. In addition, individual adjposemuscle-, and Schwann cells are enveloped by a BM (1). BM consist of various components, of which type IV collagen (2), laminin (3), heparan sulphate proteoglycan (4), nidogen/entactin $(\$, 6)$ are localized up to now in all BM. Epidermal BM furthermore contains components which are not localized in all $\mathrm{BM}$, such as bullous pemphigoid-, cicatricial pemphigoid-, and epidermolysis bullosa acquisita antigen (7), type VII collagen $(8,9)$ and hitherto unidentified components recognized by monoclonal antibodies e.g. KF-1 (10), AF1 and 2 (11) and LDA-1 (12).

The cornea is a specialized ectodermal structure. Newsome et al. (13), Guillaumin et al. (144), and Nakayasu et al. (15) reported that type IV collagen and laminin occur throughout the entire human corneal epithelial BM. However, in the rabbit $(16,17)$, guinea pig and chicken $(18,19)$ and in man $(20,21,22)$ it has been shown that in the central corneal epithelial BM type IV collagen is largely, if not completely, absent albeit it is abundantly present in conjunctival epithelial and vascular BM. Also in the stroma isolated structures are reactive with antibodies directed against type IV collagen and laminin. These strucures may be remnants of embryonic vessels (16) or Schwann cell BM (17).

In the present study we have investigated whether BM heterogeneity occurs in the human comea, similarly to the staining pattern for type IV collagen in rabbit and chicken comea. Therefore, the epithelial BM composition was studied by immunohistochemistry. Corneas were stained with a panel of polyclonal- as well as monoclonal antibodies directed against type IV collagen, type VII collagen, laminin and heparan sulphate proteoglycan. Furthermore the ultrastructure of the epithelial-stromal interface was studied in central and peripheral parts of the comea.

\subsection{Materials and methods}

\subsubsection{Antibodies}

Antibodies used in this study were monoclonal $(1042,1043$ and 1087$)$ and polyclonal antitype IV collagen antisera (23 and chapter 2), monoclonal (4E10) and polyclonal antilaminin ( $57 \mathrm{E} / 6$ ) antibodies (24), a monoclonal anti-type VII collagen antibody (9) and at monoclonal anti-heparan sulphate proteoglycan antibody. The specificties of these antibodies are outlined in chapter 9.4 .

\subsubsection{Tissues}

Eight adult human corneas were obtained at autopsy. The corneas were partly fixed in $4 \%$ buffered formalin and embedded in Paraplast or mounted in OCT-compound (Lab-Tek products, Naperville, USA) and snap frozen in isopentane quenched in liquid nitrogen. 


\subsubsection{Immunohistochemistry}

Frozen corneas were cryostat sectioned and fixed in acetone, treated with $\mathrm{H}_{2} \mathrm{O}_{2}$ in methanol to block endogenous peroxidase activity and incubated with monoclonal-or polyclonal antibodies. After washing with PBS the sections were incabated with peroxidase labeled conjugate. Immunoreactivity was visualized by incubation with diaminobenaidine$\mathrm{H}_{2} \mathrm{O}_{2}$ substrate. Paraffin sections were deparaflinized, rehydrated and blocked for andogenous peroxidase. To obtain immunoreactivity with type IV collagen and laminin these sections required treatment with $0.1 \%$ pepsin (Boehringer, Mannheim, FRG) in $0.1 \mathrm{~N}$ $\mathrm{HCl}$ (30 min, RT). Further immunohistochemical procedures were identical to those described for frozen sections (chapter 9.2 and 9.3 ).

\subsubsection{Tissue pretreatment}

Frozen as well as paraffin sections were pretreated with various enzymes in onder to unmask the immunoreactivity of BM components. For paraffin sections we used $0.19 \%$ pepsin (Boehringer, Mannheim, FRG) in $0.1 \mathrm{~N} \mathrm{HCl} \mathrm{(30} \mathrm{min,} \mathrm{RT)} \mathrm{or} 0.04 \%$ pronase (Boehringer, Mannheim, FRG) in $50 \mathrm{mM}$ Tris- $\mathrm{HCl} \mathrm{pH} 8.0\left(30 \mathrm{~min}, 37^{\circ} \mathrm{C}\right.$ ) or $0.1 \%$ hyaluronidase (Cooper Biomedical) in $0.1 \mathrm{M}$ sodiumphosphate buffer $(0.15 \mathrm{M} \mathrm{NaCl}, \mathrm{pH} 4.5,30 \mathrm{~min}$, RT). Frozen sections were pretreated with various dilutions of the same enzymes. Other sections were pretreated with various concentrations of guanidiniumhydrochloride 4 or 6 M in $50 \mathrm{mM}$ sodium acetate, $50 \mathrm{mM}$ EDTA, pH $6.5,30 \mathrm{~min}, \mathrm{RT}$, or with 0.1 or $0.5 \mathrm{M}$ acetic acid, 30 min, RT $(25,26)$. Frozen sections were preincubated with reducing $(1 \mathrm{mM}$ sodium periodate) and oxidizing (0.5\% sodium borohydrate) agents diluted in PBS with different time intervals $(27,28)$.

\subsubsection{Electron microscopy}

Corneal specimens of $1 \mathrm{~mm}^{3}$ from the central and peripheral part were fixed in $2.5 \% \mathrm{glu}$ taraldehyde in $0.1 \mathrm{M}$ sodium phosphatebuffer $\mathrm{pH} 7.2$, postfixed 1 hr in 1 o $\mathrm{OsO}_{4}$, dehydrated in a graded series of alcohols and embedded in Epon. Ultrathin sections were stained with uranyl acetate and lead citrate.

\subsection{Results}

Cryostat and paraffin sections (the latter after pretreatment with pepsin) were stained with amtibodies against BM constituents (Table I, Fig 1).

Type IV collagen was abundantly present in the epithelial BM of the limbus and conjunctiva and in vascular $B$ M. The central comeal epithelial BM, however, lacked immunoreactivity with monoclonal- but also with polyclonal antibodies directed against human type IV collagen. As soon as Bowman's membrane appeared in the limbal/corneal transition, type 
IV collagen immunoreactivity diminished and within a short distance disappeared completely (Fig 1B). Antibodies directed against other epidermal BM components such as laminin and heparan sulphate proteoglycan showed continuous reactivity of the conjunctivalu and limbal epithelial/stromal interface and the corneal epithelial/Bowman's membrane interface, whereas Bowman's membrane itself showed no immunoreactivity with these antibodies. With polyclonal anti-laminin antisera, in addition to corneal epithelial BM reactivity, strong supranuclear intracytoplasmic staining was observed only in basal corneal cells. To determine whether the central corneal epithelial BM lacked type IV collagen, or alternatively the epitopes were masked by other constituents such as proteoglycans or glycoproteins, paraffin- and cryostat sections were pretreated with various concentrations of enzymes e.g. pepsin, irypsin, collagenase/dispase and hyaluronidase (17), with various concentrations of guanidinium hydrochloride to extract proteoglycans or with acetic acid which causes swelling or conformational changes within type IV collagen containing fibrils. Other tissue sections were pretreated with reducing or oxidizing agents. Despite these attempts to unmask the type IV collagen epitopes, no immunoreactivity with the monoclonal and polyclonal antibodies to type IV collagen could be obtained in the central epithelial corneal BM.

Table 1. Immunoreactivity for BM components in the human cornea

\begin{tabular}{|c|c|c|c|c|c|c|c|}
\hline antibody & $\begin{array}{l}\text { corneal } \\
\text { ep BM }\end{array}$ & $\begin{array}{l}\text { limbal/con- } \\
\text { junctival BM }\end{array}$ & $e p$ & $\begin{array}{l}\text { Bowman's } \\
\text { membrane }\end{array}$ & $\begin{array}{l}\text { Descem } \\
\text { membra } \\
\text { stromal } \\
\text { face }\end{array}$ & $\begin{array}{l}\text { et's } \\
\text { ne } \\
\text { central } \\
\text { face }\end{array}$ & $\begin{array}{l}\text { endothelial } \\
\text { face }\end{array}$ \\
\hline $\begin{array}{l}\text { ma type IV } \\
\text { collagen }\end{array}$ & - & + & - & - & + & - & - \\
\hline $\begin{array}{l}\text { pa type IV } \\
\text { collagen }\end{array}$ & - & + & - & - & + & + & - \\
\hline ma laminin & + & + & - & - & - & - & + \\
\hline pa laminin & + & + & $*$ & - & - & - & + \\
\hline $\begin{array}{l}\text { ma type VII } \\
\text { collagen }\end{array}$ & + & + & - & - & - & - & - \\
\hline ma $\mathrm{HSPO}$ & + & + & - & - & - & - & + \\
\hline
\end{tabular}

ma $=$ monocional; $\mathrm{pa}=$ polyclonal antibody, $\mathrm{HSPG}=$ heparan sulphate protegglycan; * = supranuclear staining in basal cells; ep = epithelium 

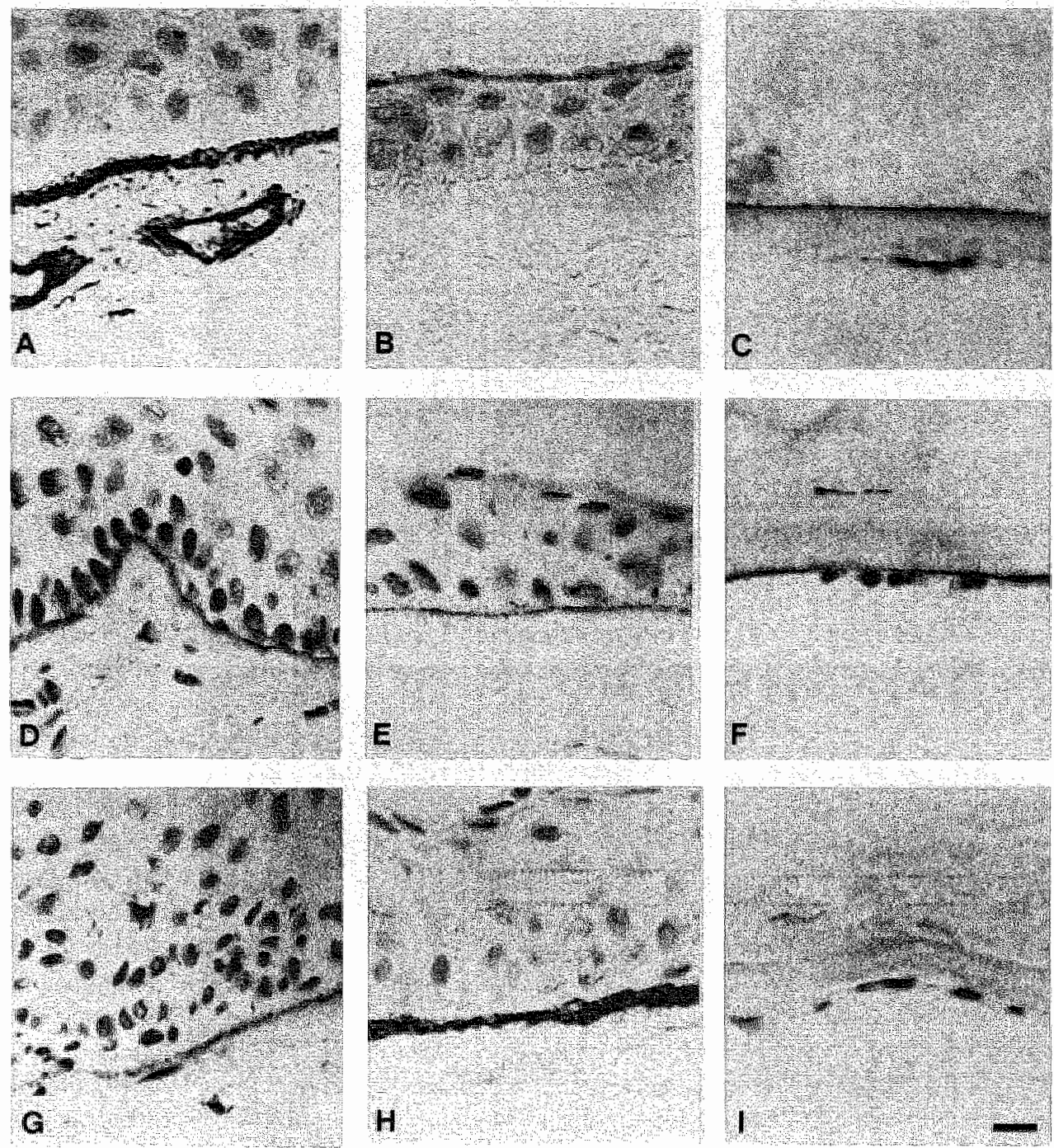

Figure 1. Immunoperoxidase staining pattern of frozen human corncal epilhelial BM. Conjunctivallimbus ( $A$. $D, G)$, Central comea ( $B, E, H)$, Descemet's membrane $(C, F, 1)$, were stained using anibodies lo lype IV onlagen $(A, B, C)$, haminin $(D, E, F)$ and type VII collagen $(G, H, 1)$. Scalle bar $=20 \mu \mathrm{m}$. 

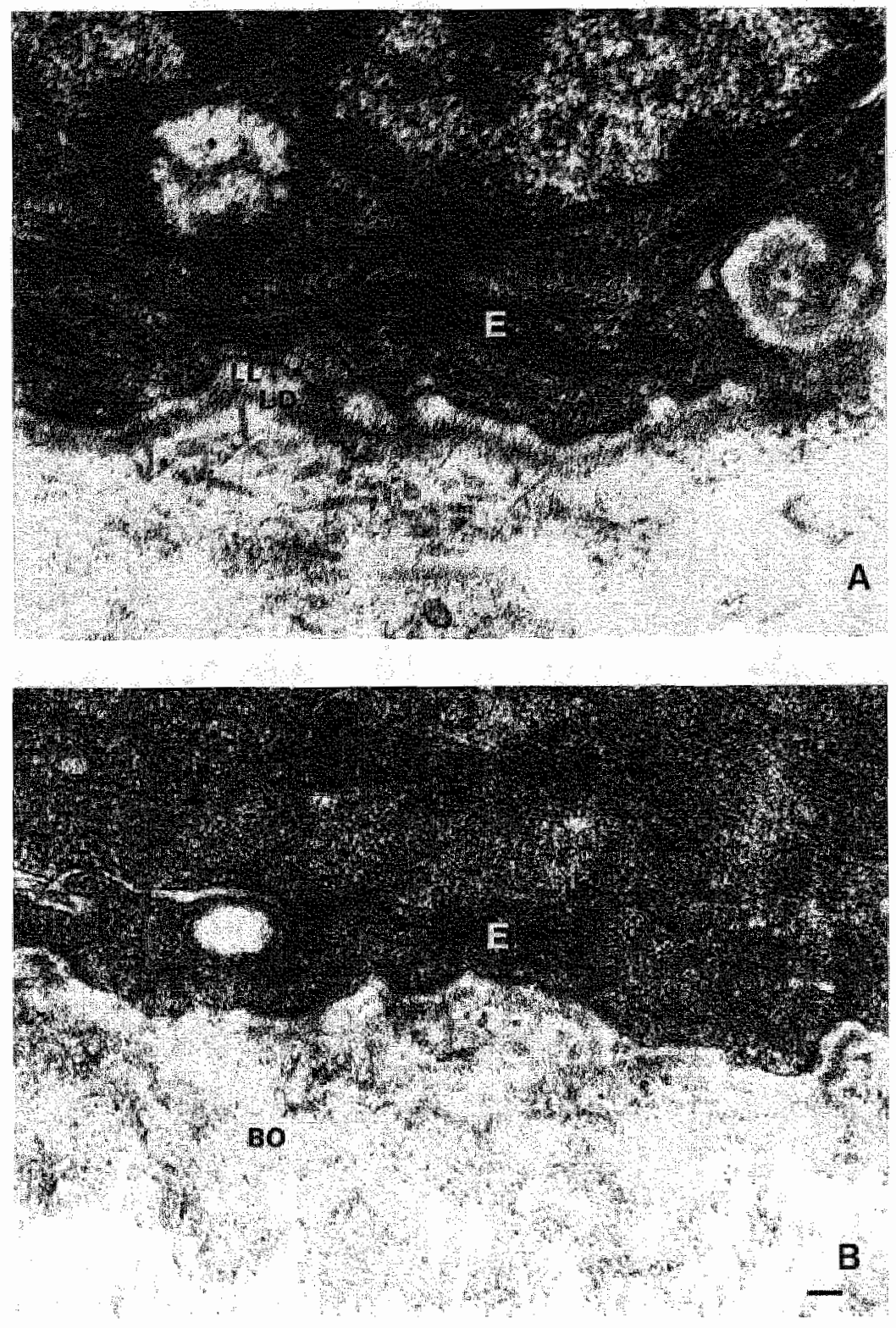

Figure 2. A. Electronmicrograph of peripheral (conjunctival) human comeal epithelial BM. B. Elconor-

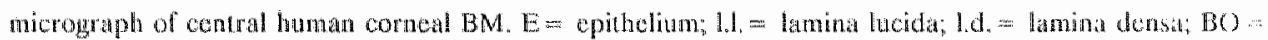
Bowmon's membrane. Scale batr $=0.5 \mu \mathrm{m}$. 
Descemet's membrane reacted with antibodies to laminin and heparan sulphate proteoglycan, exhibiting a linear staining pattern only whith the endothelial face of this membrane. In contrast, with monoclonal anti-type IV collagen antibodies only the stromal face of Descemet's membrane reacted. With polyclonal anti-type IV collagen antisera the entire Descemet's membrane showed weak immunoreactivity in addition to the stromal staning pattern. The immunohistochemical results were identical on frozen and cryostat sections. Ultrastructurally, differences were observed between the peripheral and central corneal BM. Normal lamina lucida and lamina densa were observed in limbal and conjunctival BM (Fig 2A). In the central area of the cornea the BM showed a lamina lucida, however the lamina densa was absent or less distinct in comparison to the peripheral part of the comed. Electron dense depositions directly underlying the lamina lucida were considered to represent parts of hemidesmosomes. Elsewhere the lamina lucida was in direct contact to the Bowman's membrane (Fig 2B).

\subsection{Discussion}

Type IV collagen is regarded as the structural backbone of all BM $(1,29)$. Present data however show that some parts of the BM may not contain type IV collagen and/or be reactive with some antibodies to this type of collagen. Within a single continuous (corneal) BM heterogeneous reactivity occurs with antibodies to human type IV collagen. In the central corneal epithelial BM, type IV collagen could not be detected with the used antibodies, whereas this component was abundantly present in the limbal-, conjunctival-, and vascular BM. This is in contrast to earlier findings in which the human cornea showed a linear staining for type IV collagen of the whole corneal epithelial BM (13-15). In the human cornea, we found that conjunctival and limbal BM have a normal ultrastructural appearance with a lamina lucida and lamina densa, whereas in the aduit central corneal BM the lamina densa is not as distinct as in the periphery of the cornea or indeed totally absent. The lamina lucida appeared to be directly attached to the Bowman's membrane. These findings support the contention that type IV collagen is predominantly localized in the lamina densal (30, 31). Immuno-electron microscopic investigation with antibodies to type IV collagen, which localize type IV collagen throughout lamina densa and lamina lucida, as well as modelstudies on BM reconstitution from isolated BM components (type IV collagen, laminin and heparan sulphate proteoglycan) suggest that these components are codistributed, although they do not rule out the possibility that the relative proportions of these components may vary (32).

For the absence of type IV collagen immunoreactivity in the central cornea several explanations should be considered. Firstly, type IV collagen could be completely absent. In this situation the BM scaffold could consist of a component, different from type IV collagen, 10 which the other components are attached. Secondly, an altered type IV collagen might be deposited, which does not react with our anti-type IV collagen antibodies, as was earlier suggested by Fitch et al. (19). Thirdly, a BM might be altogether absent. In this situation, 
Bowman's membrane could take over its function. Other BM components, such as laminin and heparan sulphate proteoglycan were detected in the interface between epithelium and Bowman's membrane. It is therefore unlikely that the entire BM is missing; more likely the function of type IV collagen is taken over by another component. Fourthly, it is possible that in the central coneal region type IV collagen determinants are masked by othe BM components such as glycoproteins or proteoglycans (16). However, pretreatment of the tissue with various enzymes or agents which cause elution of proteoglycans, swelling of the tissue or conformational changes within the BM components did not restore immumoreactivity with any of the antibodies used in this study. Fifthly, the absence of humoral and stromal stimuli for the production of BM components might explain the lack of type IV collagen. This might be envisioned as basal corneal epithelial cells are implanted on an acellular and avascular specialized stroma (Bowman's membrane) and are consequenty devoid of a normal epithelial-stromal transition. Finally, central basal corneal cells are highly differentiated cells, which might have lost the capability of type IV collagen production. Central corneal epithelial cells are not capable of replication in culture, whereas peripheral/limbal comeal epithelium maintains the potential of duplication in vitro $(33,34)$. Schermer et all. (34), and Rodrigues et al. (35) postulated the existence of corneal stem cells in the limbus. This contention is supported by the pattern of expression of a $64 \mathrm{kD}$ keratin, which is correlated with specific epithelial differentiation and shows a suprabasal localization in the limbus, and a basal localization in the central connea (Cleutjens et all., unpublished observations). Furthermore the observed centripetal migration of corneal epithelial cells from the limbal area and the higher mitotic activity of the limbal cells compared to the central comeal cells supports this hypothesis.

Antibodies to laminin and heparan sulphate proteoglycan reacted with all BM and on ly differences in staining intensity have been observed. In our experiments the central corneal BM showed less intense staining for laminin and heparan sulphate proteoglycan compared to the limbal/conjunctival BM staining, which is similar to the findings for type IV collagen in the human cornea by others $(13,14)$. The presence of type VII collagen and the absence of type IV collagen immunoreactivity in the central corneal region implies that type IV collagen is not the only possible junctional element in linking the carboxyl-terminal domain of type VII collagen in anchoring plaques and BM (36). In the cornea, type VII collagen must bind to other BM components. The attachment site could be the hemidesmosome because hemidesmosomes and anchoring fibril collagen appear synchronously during development and wound healing (37).

Heterogeneity in BM composition was found also in Descemet's membrane. With antibodies to laminin and heparan sulphate proteoglycan only the endothelial face of Descemet's membrane showed delicate linear staining. In contrast, monoclonal antibodies to type IV collagen showed only immunoreactivity with the stromal face, whereas polyclonal antisera stained the stromal face with occasional faint staining of the central part of Descemet's membrane. These findings make it likely that Descemet's membrane is a true BM formed by endothelial cells (34). This membrane may in addition contain other compow 
nents which are not generally found in BM (39). In contrast to Descemet's membrane, Bowman's membrane is a modified stromal membrane and it did not react with warious antibodies to BM components.

From these results we conclude that central human corneal epithelial BM lacks type IV collagen. Consequently, the basic structure of this BM is different from that of other BM.

\subsection{References}

1. Martinez-Hernanded A, Amenta PS: The basement membrane in Pathology. Lab Inwest 48, 650,1983

2. Miller E, Gay S: The multiple types and formes of collagen. Meth Enzymology $82 \mathrm{~A}, 3,1982$

3. Timpi R, Rohde M, Robey P, Rennard S, Foidart J-M, Martin G: Laminin: a dycoprotein from basement membranes. J Biol Chem 254, 9933,1979

4. Caughman S, Krieg T, Hintner $H$, Timpl R, KatzS. Nidogen and heparan sulphate proteoglycan: detection of newly isolated basement membrane components in normal and epidermolysis bullosa (EB) stin. Chin Res 33, 297A, 1985

5. Timpl R, Dziadek M, Fujiwara $S$, Nowack $H$, Wick G: Nidogen, at new, self-aggregating basement membrane protein. Eur J Biochem $137,455,1983$

6. Carlin B, Jaffe R, Bender B, Chung AE: Entactin, a novel basal lamina-associated sulfated glycoprotcin $\mathrm{J}$ Biol Chen 256, 5209, 1981 .

7. Fine JD: Cicatricial pemphigoid, Bullous pempligoid, and opidurmolysis Bullosa Aquisita antigens: Dilferences in organ and species specificities and localization in chemically separated human skin of the threo basement membrane antigens. Collagen Rel Res 5, 369, 1985

8. Leigh 1, Purkis P: LH 7:2 -a new monoclonal antibody to a lamina densa protein. J Invesi Derm 84, 448, 1985

9. Sakai LY, Keene DR, Morris NP, Burgeson RE: Type VII collagen is a major structural component of anchoring fibrils. J Cell Biol 103, 1577, 1986

10. Breathnach $S$, Fox P, Neisis $G$, Stanley J, Katz S: A unique squamous epithelial basement membrane anligen defined by a monoclonal antibody (KF.1). J Invest Derm 80, 392, 1983

11. Goldsmith L, Briggaman R: Monoclonal andibodies to anchoring fibrils for the diagnosis of epidernolysis bullosa. f favest Derm 81, 464, 1983

12. Fine JD, Gay S: LDA-1: A ubiquitous noncollagenous lamina densa component of basement membranc detected by monoclonal antibody technique. J Inwest Dermatol \$6, 286, 1986

13. Newsome DA, Foidart J-M, Hassell JR, Krachmer JH, Radrigues MM, Katz SI: Detection of specific col-

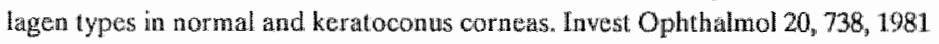

14. Guillaumin EA, Fujikawa LS, Vastine DW, Foster CS, Colwin $\mathbb{R} B$ : Basement membrane components in normal human corneas from various age groups. Invest Opththallmol Vis Sci 22, 72 (suppl), 1982

15. Nakayasu $K$, Taraka $M$, Konomi $H$, Hayashi $T$ : Distribution of type $1,11, \Pi H$, $\mathbb{V}$ and $V$ collagen in normal and keratoconus corneas. Ophthalmic Res. 18, 1, 1986

16. Fujikawa LS, Foster CS, Gipson IK, Colvin RB: Basement membrane components in healing rabbil corneal epilbelial wounds: Inmunofluorescence and ultrastructurat situdies. J Cell Biod 98, 128, 1984

17. Peavy D, Bogos $S$, Gebhardt B, Beuerman R: Immunohistochemical differentiation of Schwann and epithelial basal lemina in the rabbit conca. Neuroscience Letters $79,40,1987$

18. Fitch JM, Gibncy E, Sanderson RD, Mayne R, Linsenmayer TF: Domain and basement membrane specificity of a monoclonal antibody against chicken type IV collagen. I Cell Biol $95,641,1982$ 
19. Fitch M, Linscrnayer TF: Mowoclonal antibody analysis of ocular basement membranes during dewelopment. Dew Bul 95, 137, 1983

20. Odermat BF, Lang AB, Rituner JR, Winterthalter KH, Trueb B: Monoclomal antibodies to hunan type IV collagera: Utefist reagents to demonstrate the heterotrimeric narure of the molecule. Proc Natl Acad Sci USA 81, 7343, 1984

21. Scheinman JI, Tsai C: Monodonal antibody to type IV collagen with selective basement membrane localization. Latb lnvest $50,101,1984$

22. Sundaraj $\mathrm{N}_{3}$ Willson I: Monoclonal anubody lo human basement membrane collagen ype IV. Immunology $47,133,1982$

23. Haverith MG, Cleutens JPM, Bewe $C$, wan der Linden E, de Goey AFPM, Bosman FT: Hunan specific anti- type IV collagen monoctonal antibodies, characterization and immunohistochemical application. Histochentistry $87,123,1987$

24. Wewer U, Abrectsen R, Mathorpe M, Varon S, Engvall E, Ruoslahti E: Human laminin ssolated in a nuarIy inact, biologically active form from placenta by limted proteolysis. J Biol Chem 258, 12654, 1983

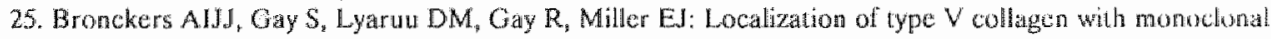
antibodies in developing dental and peridental tissues of the rat and the hamster. Collagen Rel Res $\sigma_{4} 1$, 1986

26. Linsenmayer TF, Fitch JM, Schmid T, Zak, NB, Gibney E, Sanderson RD, Mayne R: Monoclonal antibodies against chick type $\mathrm{V}$ collagen: production, specificity, and their use for inmunocytological localization in embryonic cornea and other organs. J Cell Biol 96, 124, 1983

27. Horikoshi $\mathrm{S}$, Koide $\mathrm{H}_{\mathrm{x}}$ Shirai $\mathrm{T}$ : Monoclonal antibodies aganst laminin $\mathrm{A}$ chain and $\mathrm{B}$ chain in the human and mouse kidnews. Lab Invest $58,532,1988$

28. Laurie GW, Leblond CP, Inoue S, Martin GR, Chung A: Fine structure of the glomerular basement membrane and immunolocalization of five basement membrane components to the lamina densa (basal lamina) and its extensions in both glomeruli and tubules of the rat kidney. Am Inat $169,463,1984$

29. Bosman FT, Havenith M, Cleutjens JPM: Basement membranes in cancer. Ultrastruct Pathol 8, 291, 1985

30. Courtoy PJ, Timpl R, Farquhar MG: Comparative distribution of laminin, type IV collagen, and Fibronectin in the rat glomerulus. J Histochem Cytochem 30, 874, 1982

31. Farquhar MG: The glomerular basement membrane. A selective macromolecula filter. In: Cell Biology of extracellular matrix. Hay ED, ed. Plenum Press, New York 335, 1981

32. Yurchenco PD, Tsilibary EC, Charonis AS, Furthmayr H: Models for self-assembly of basement membrane. J Histochem Cytochem 34,93, 1986

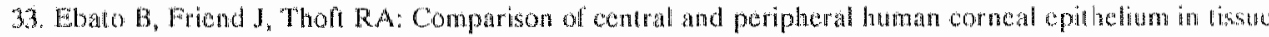
culure. Invest Ophunalmol Vis Sci $28,1450,1987$

34. Schermer $A$, Ofulvin $S$, Sun $T-T$; Differrentiation-related expression of a major $64 \mathrm{~K}$ corneal kerath in wivo and in culture suggests limbal location of corneal epithelial stem cells. J Cell Biol 103, 49, 1986

35. Rodrigues M, Beri-Zvi A, Kruchmer J, Schermer A, Sun T-T: Suprabasal expression of a 64-kilodallon keratin (no. 3) in developing human corneal epithelium. Differentiation 34, 60, 1987

36. Keene DR, Sakai LY, Lunstrum GP, Morris NP, Burgeson RE: Type VIl collagen forms an extended network of anchoring Gibrils. J Cell Biol 104, 611, 1987

37. Gipson IK, Spurr.Michaud SJ, Tisdale. AS: Hemidesmosomes and anchoring fibril collagen appear synchronously during development and wound healing. Dev Biol 126, 253, 1988

38. Spencer WH: Cornea. Ophthalmic Pathology. An atlas and textbook. Saunders company. Volume 1, 1985

39. Hay ED, Linsenmayer TF, Trelstad RL, von der Mark K: Origin and distribution of collagen in the develo-

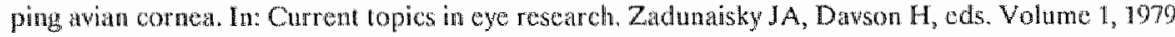




\section{Chapter 5}

\section{Umbilical cord stromal cells are myofibroblasts: isolation, immunohistochemical and ultrastructural characterization*}

* Cleuijens JPM, Vallinga M, Beek C, ten Kate J, Bosman FT.

Subnitled for publication. 


\subsection{Introduction}

The myofibroblast is a much disputed member of the mesenchymal cell family. Cells with structural and functional characteristics of fibroblasts and smooth muscle cells were first described in experimentally induced wounds and granulation lissue (1). The myofibroblaw is morphologically characterized by a fibroblastic-type rough endoplasmic reticulum and peripheral parallel cytoplasmic filaments with dense body condensations characteristic of myofilaments. Basement membrane-like structures are found around the myofibroblast as a cell-coat or as discontinuous plaques. In close apposition to this basement membranelike material often hemidesmosome-like attachment bodies are observed. Myofibroblasts display extensive cell-matrix interactions: intracellular actin-filaments are attached to a hemidesmosomal plaque, whereas collagen fibers are arranged extracellularly in anchoring strands (2) and extracellular fibronectin into a fibronexus (3). Furthermore myofibroblasts are attached to each other by desmosome-like structures. When the cell contracts, the whole tissue architecture will be altered. Myofibroblasts contract and relaxate on the same pharmacologic stimuli as smooth muscle cells. Along with fibroblasts, these cells produce collagen and elastin $(4,5)$ and conceivably various other extracellular matrix components.

Myofibroblasts play an important role in some pathologic conditions connected with e.g. tissue repair, such as wound healing or the desmoplastic reaction in neoplasia. In neoplasia, when the desmoplastic response is inhibited by dehydroproline, invasive growth and metastasis are increased and this is accompanied by a decrease in collagen synthesis ( 6 ). In coculture experiments of myofibroblasts with tumor cells, the growth of the tumor cells was inhibited due to a still unidentified synthesized pronase susceptible protein (7).

The origin of myofibroblasts is still under discussion. They might be derived from a mesenchymal stem cell or differentiate from fibroblasts and/or smooth muscle cells $(4,5)$. Studies of the biology of myofibroblasts would be greatly facilitated by availability of model systems in which these cells could be manipulated. We therefore investigated the possibility to culture myofibroblasts from umbilical cord stroma. The present report describes these cells in the umbilical cord stroma, their tissue culture and their immunophenotype and ultrastructure.

\subsection{Materials and methods}

\subsubsection{Antibodies}

Monoclonal and polyclonal antibodies aganst type IV collagen, laminin, desmin, vimentin* fibronectin, factor VIII, actin and myosin were used in this study. The characteristics and source of the antibodies are extensively specified in chapter 9.4 . 


\section{2 .2 Tissue culture}

Human umbilical cords were obtained directly after delivery. The stromal part of this tissue was excised and washed several times in phosphate buffered saline (PBS) with 50 Units/ml penicillin and $50 \mu \mathrm{g} / \mathrm{ml}$ streptomycin (per/strep). The little fragments of stromal tissue were cultured in Dulbecco's modified Eagles minimum essential medium supplemented with $10 \%$ fetal calf serum and pen/strep using a $37^{\circ} \mathrm{C}$ incubator with $5 \% \mathrm{CO}$. After one to two weeks cells grew out from these explants. These cells were removed by irypsinization and cultured under pen/strep free culture conditions. To culture human skin fibroblasts, human dermis was used as explant. Cells were cultured either on tissue culture plastics, on $1 \%$ gelatin coated glass slides or in and on type I collagen lattices. Type I collagen lattices were prepared as described previously $(8,9$, chapter 9.8$)$ by mixing a cold stock solution of type I collagen isolated from human placenta $(4 \mathrm{mg} / \mathrm{ml}$ in $0.1 \% \mathrm{HAc})$ with culture medium and $0.1 \mathrm{~N} \mathrm{NaOH}$ to neutralize the $\mathrm{pH}$. The endconcentration of type I collagen was $0.7,1$ or $2 \mathrm{mg} / \mathrm{ml}$. Reaggregation took place as soon as the solution was neutralized and brought to $37^{\circ} \mathrm{C}$.

\subsubsection{Electron microscopy}

Tissue fragments of approximately $1-2 \mathrm{~mm}^{3}$ were fixed in $2.5 \%$ glutaraldehyde in $0.1 \mathrm{M} \mathrm{so-}$ dium phosphatebuffer $\mathrm{pH} 7.2$, postfixed 1 hr in $1 \% \mathrm{OsO}_{4}$, dehydrated in a graded series of alcohols and embedded in Epon. Ultrathin sections were stained with uranyl acetate and lead citrate.

\subsubsection{Immunohistochemistry}

Western blots, dot blots, paraffin- and frozen sections were stained with an indirect immunoperoxidase method as described in chapter 9.2. Briefly, frozen sections were air-dried and fixed in acetone. Paraffin sections were first deparaffinized. The sections were washed with PBS and incubated with the specific antibodies. After washing with PBS the sections were incubated with peroxidase labeled conjugate. After washing with PBS, peroxidase activity was visualized by incubation with diaminobenzidine- $\mathrm{H}_{2} \mathrm{O}_{2}$ substrate.

Before applying the specific antibody to western and dot-blots the nitrocellulose paper was treated with PBS and $1 \%$ Bovine serum albumin or $0.3 \%$ Tween 20 to prevent aspecific binding of the antibodies.

\subsubsection{Electrophoresis and western blotting}

Culture supernatants were precipitated wit] $4.5 \mathrm{M} \mathrm{NaCl}$ or $50 \%$ ammoniumsulphate, dialyzed against $0.1 \mathrm{M}$ Tris- $\mathrm{HCl}$ and electroblotted (10) after $5 \%$ polyacrylamide gel electrophoresis (11, chapter 9.5). 
After western blotting the strips of nitrocellulose paper were stained with polyclonal antitype IV collagen and laminin antisera as described under immunohistochemistry (chapter $9.2)$.

\subsubsection{Immunoaffinity purification}

Monoclonal anti-buman type IV collagen antibody (1043) was coupled to Affigel-prot A (Bio-rad). Culture supernatant was used undiluted or precipitated with $50 \%$ ammonim sulphate $\mathrm{pH} 7.4$, dialyzed against phosphate buffered saline and incubated overnight at 4 ${ }^{\circ} \mathrm{C}$ on a roller bank. After washing 4 times (with $50 \mathrm{mM}$ Tris, $150 \mathrm{mM} \mathrm{NaCl}$, pH 7.4), the affinity purified material was eluted with $0.02 \mathrm{M} \mathrm{HAc}, 150 \mathrm{mM} \mathrm{NaCl}$, dialyzed against distílled water and freeze dried.

\subsubsection{Northern blotting}

Cultured cells were isolated by trypsin digestion and cytoplasmic RNA was isolated by resuspending the cell pellet (12). The nuclear pellet was removed, the supernatant extracted with phenol-chloroform and the RNA was precipitated in ethanol. "Total RNA was separated by electrophoresis in agarose-formaldehyde gels and blotted overnight onto a genescreen filter. The blot was air dried, baked, and prehybridized during in a solution containing $\mathrm{NaCl}, \mathrm{Na}$-citrate, Na-phosphate, polyvinyl pyrrolliclone, bovine serum albumin, ficoll, denaturated salmon sperm DNA and formamide. Hybridization of RNA-cDNA was carried out in the same solution containing the labeled type IV collagen cDNA probe (13). The type IV collagen probe was labeled with the random primer labeling method $(14,15)$ with ${ }^{32}$ P-dCTP. After hybridization the filter was washed, dried and autoradiographed using Kodak X-Omat films. This method is extensively outlined in chapter 9.6.

\subsubsection{In situ hybridization}

$4 \mu \mathrm{m}$ frozen sections were mounted on RNAse free coated slides, fixed with freshly prem pared $4 \%$ paraformaldehyde and washed with PBS, baked, washed again and treated with Triton X-100. After washing in PBS the sections were incubated with proteinase $K$ in a bulfer containing Tris, and EDTA. The sections were fixed again with $4 \%$ buffered parafornaldehyde, washed with PBS and treated with acetic anhydride in triethanolamine and furthermore incubated with formamide in $2 \times$ SSC. ${ }^{35}$ S-dCTP labeled type $\mathbb{V}$ collagen probe (13) was prepared according to the random primed labeling method using a Boehringer labeling kit $(14,15)$. $15 \mu$ probe/hybridization mixture containing $300,000 \mathrm{cpm}$ was applied to each section. The sections were subsecuently covered with $22 \times 22 \mathrm{~mm}$ siliconized coverslips and sealed with rubber cement. Hybridization mixture contained yeast t-RNA, salmon sperm DNA, deionized formamide, Tris- $\mathrm{HCl}, \mathrm{NaCl}$, EDTA, Denhardt"s mixture, Dextran sulphate, and DTT. After $12-16$ h incubation at $50^{\circ} \mathrm{C}$, the coverslips were removed and the slides were washed with SSC. Following these steps the slides were dehy- 
drated in graded series of ethanol, air dried and coated with Kodak NTB-2 nuclear track emulsion and exposed for varying periods of time. The exposed slides were developed in 11 Kodak D-19 developer fixed, and counterstamed with hematoxylin, dehydrated und mounted. Parallel sections were hybridized with a ${ }^{35} \mathrm{~S}$ labeled empty plasmid as a negative control. This method is extensivley clescribed in chapter 9.7 .

\subsection{Results}

\subsubsection{Cell morphology}

The fibroblast-like cells in the stroma of the umbilical cord are characterized electron microscopically by a fibroblast-type of rough endoplasmic reticulum, an undulating nucleus, dense bodies, myofilaments, focal pericellular basement membrane depositions, and desmosome-like cell contacts (Fig 1 and 2).

Following in vitro explantation of umbilical stroma, spindle shaped cells grew out within two weeks. The stromal cells in vitro were flattened, elongated and sometimes sprouting, with a clear nucleus containing one or two nucleoli. The cells could be kept in continuous culture and could be subcultured in standard medium under standard conditions. A problem was cryopreservation of the cells in order to store them for longer periods.

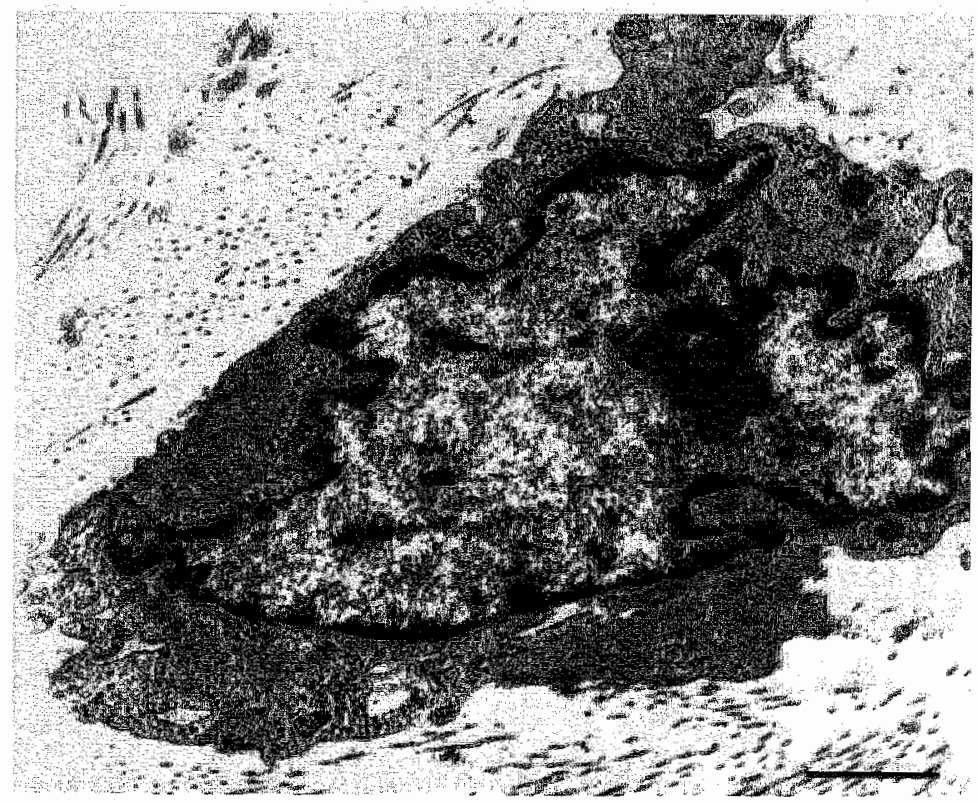

Figure 1. Electronmicrograph of myofibroblasts in the umbilical cord stroma. Scale bar $=0.1 \mu \mathrm{m}$. 

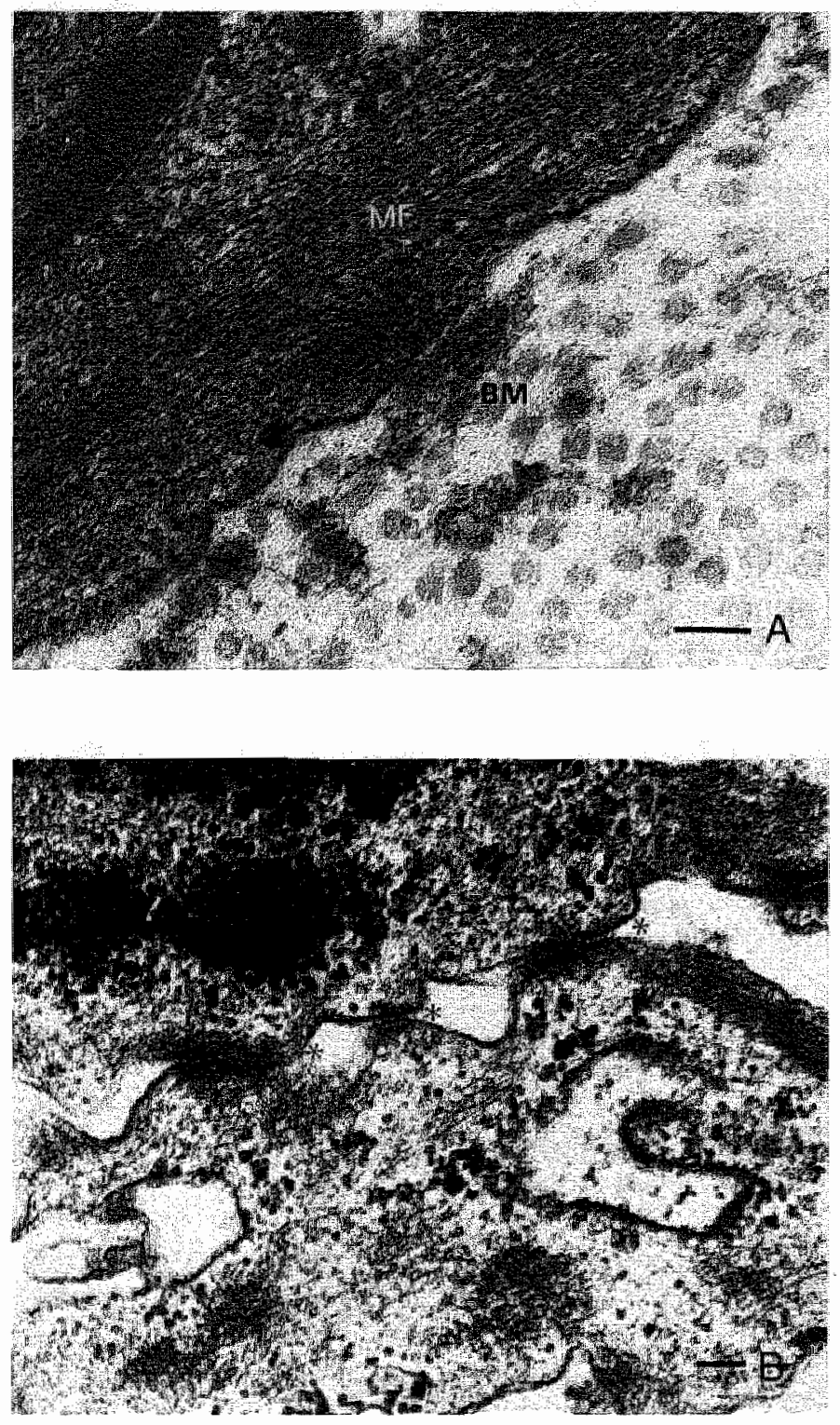

Figure 2. Electronmicrograph of myofibroblasts in the umbilical cord stroma. A: Peripheral myofilaments. (MF) and discontinuous depositions of basement membrane-like material around the cell membrane (BM). B. Desmosome like contwets between two myohbroblastic cells $\left({ }^{*}\right)$. Scate bar $=0.1 \mu \mathrm{m}$. 

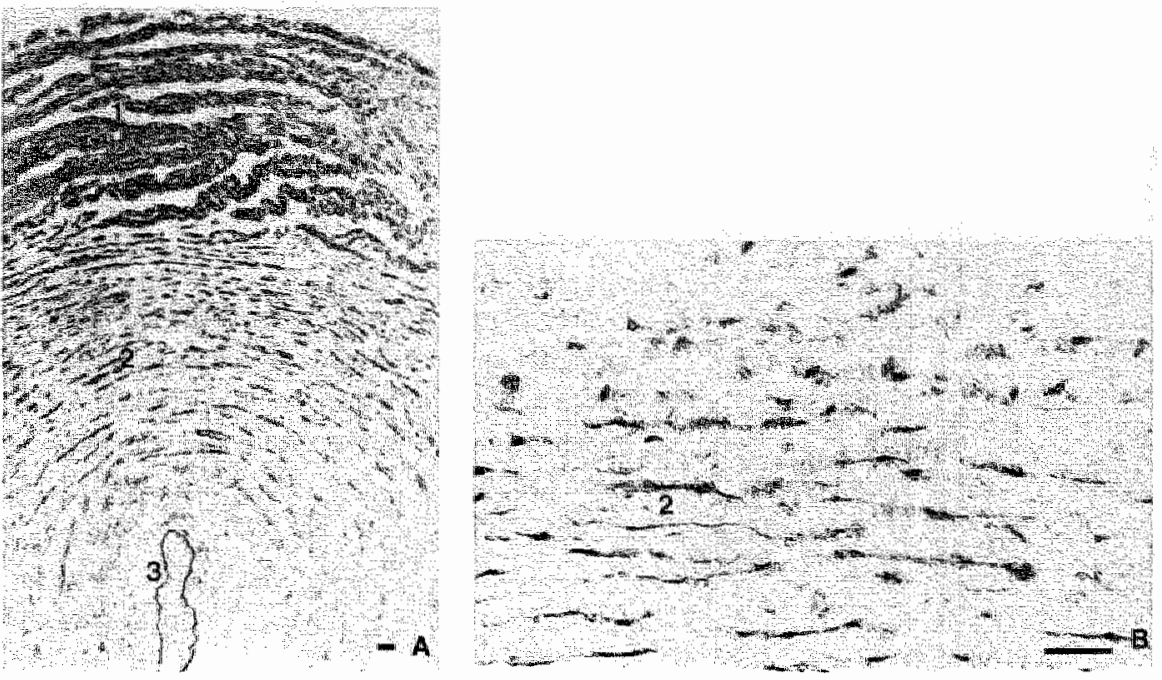

Figure 3. Immunoperoxidase staining pattern of a frozen section of human umbilical cord stained with MA 1042, directed to human type IV collagen. A: Overview, with (1) smooth muscle cell BM, (2) stromal cell BM and (3) amniotic BM. B: Higher magnification of the stromal cells statned with anti type IV collagen monoclom nal antibodies. Scale bar $=10 \mu \mathrm{m}$.

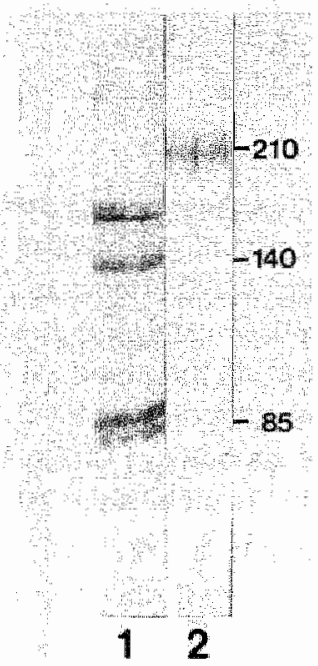

Figure 4. Immunoblot after $5 \%$ polyacrylamide gelelectrophoresis of a finity purified ype IV collingen, isoluted form tissue cutture supernatant of human um. bilical cord stromal cells in viltro, and stained with lame 1: polyclonal anti-type IV collagen andiscrum lane 2: polyclonal ani-lamimin andiserum. 
Figure 5. Northern blot of mRNA isolated from umbilical cord stromal cells in vitro, bybridized with a type IV collagen cDNA probe (lane 1) and as a control mRNA from human skin fibroblasts bybridized with the same probe (lane 2).

Several cryoprotectants, including $10 \%$ glycerol, DMSO and $100 \%$ foetal call serum were tested but after thawing, reculturing of the cells appeared to be impossible. When cultured in a lattice of type I collagen, the cells ultrastructurally resembled the stromal umbilical cord cells in vivo. They showed an undulating nucleus, rough endoplasmic reticulum, myofilaments, dense bodies, and focal extracellular basement membrane depositions. The cells contracted the lattice within a few days, similar to human skin fibroblasts.

\subsubsection{Immunophenotype}

Staining of the umbilical cord frozen sections with a panel of antibodies showed that the stromal cells stained with vimentin, desmin, $\alpha$ and $\gamma$ actin and smooth muscle myosin, suggesting that they are mesenchymal cells with contractile properties. Furthermore intracytoplasmic and/or extracellular BM components, such as type IV collagen and laminin could be observed (Fig 3), whereas this appeared to be the only cell type in the umbilical cord which produces fibronectin. When cultured on gelatin coated glass slides the umbilical cord stromal cells showed by immunohistochemistry with this panel of antibodies (Table 1) the same pattern of immunoreactivity as found for the stromal cells in the umbilical cord. 
Table 1. Immunoreactivity of umbilical cord cell types in wo and in wiro

\begin{tabular}{|c|c|c|c|c|c|c|c|c|c|}
\hline \multirow[b]{3}{*}{ Antibodies } & \multicolumn{4}{|c|}{ in vivo } & \multirow{2}{*}{\multicolumn{2}{|c|}{$\mathrm{MF}$}} & \multirow{2}{*}{\multicolumn{2}{|c|}{ Amnion }} & \multirow{3}{*}{$\begin{array}{l}\text { in with } \\
\text { UC } \\
\text { cell }\end{array}$} \\
\hline & \multicolumn{2}{|c|}{ Endo } & \multicolumn{2}{|c|}{ SMC } & & & & & \\
\hline & $\mathrm{BM}$ & cell & $\mathrm{BM}$ & cell & $\mathrm{BM}^{\mathrm{m}}$ & cell & $\mathrm{BM}$ & cell & \\
\hline $\operatorname{ma} 1042 / 1043$ & + & - & + & - & $+t$ & + & + & - & $\mathbb{*}(p c)$ \\
\hline ma 1087 & + & - & + & - & + & + & + & - & $+(\mathrm{pc})$ \\
\hline pa type IV collagen & + & - & + & - & $t+$ & + & + & - & $+(p c)$ \\
\hline $\operatorname{ma} 4 \mathrm{E} 10$ & + & - & + & - & + & + & + & - & $+(p c)$ \\
\hline pa laminin & + & - & + & - & + & + & + & - & $+(p c)$ \\
\hline pa type I collagen & - & - & - & - & - & + & - & - & + \\
\hline ma vimentin & - & + & - & + & - & + & - & + & ++ \\
\hline ma desmin & - & - & - & + & - & + & - & - & $+1-$ \\
\hline pa desmin & - & - & - & + & - & + & - & - & + \\
\hline ma a actin & - & - & - & $+t$ & - & $+t$ & - & - & ++ \\
\hline $\operatorname{ma} \alpha+\gamma \operatorname{actin}$ & - & - & - & ++ & - & ++ & - & - & ++ \\
\hline pasm myosin & - & - & - & + & - & + & - & - & + \\
\hline ma pan myosin & - & - & - & ++ & - & + & - & - & +4 \\
\hline ma myosin R11D10 & - & - & - & - & - & - & - & - & - \\
\hline ma factor VIII & - & + & - & - & - & - & - & - & - \\
\hline ma fibronectin & - & - & - & 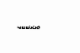 & - & + & - & - & ++ \\
\hline
\end{tabular}

$\mathrm{ma}=$ monoclonal; $\mathrm{pa}=$ polyclonal; $\mathrm{endo}=$ endothelium; $\mathrm{SMC}=$ smooth muscle cell; $\mathrm{MF}=$ myofibroblas; UC $=$ = unbilical cord stroma cell; $B M=$ basement membrane; $*$ = basement membrane-like material; sm = smooth muscle; pc = pericellular immunoreactivity

\subsubsection{Production of BM components}

Tissue culture supernatant from cultured stromal cells was affinity purified using a monoclonal antibody to type IV collagen (clone 1043). Using this method laminin copurified with type IV collagen as demonstrated by electrophoresis followed by western blotting, using polyclonal antisera to type IV collagen and laminin (Fig 4). In the cultured cells type IV collagen mRNA was detected by northem blotting. After hybridization with the type IV collagen cDNA probe, two bands were observed just above the $28 \mathrm{~S}$ ribosomal RNA band, whereas no hybridization was obtained with mRNA from normal skin fibroblasts (Fig 5). In situ hybridization on tissue sections of umbilical cord and cytospin preparations of cul- 


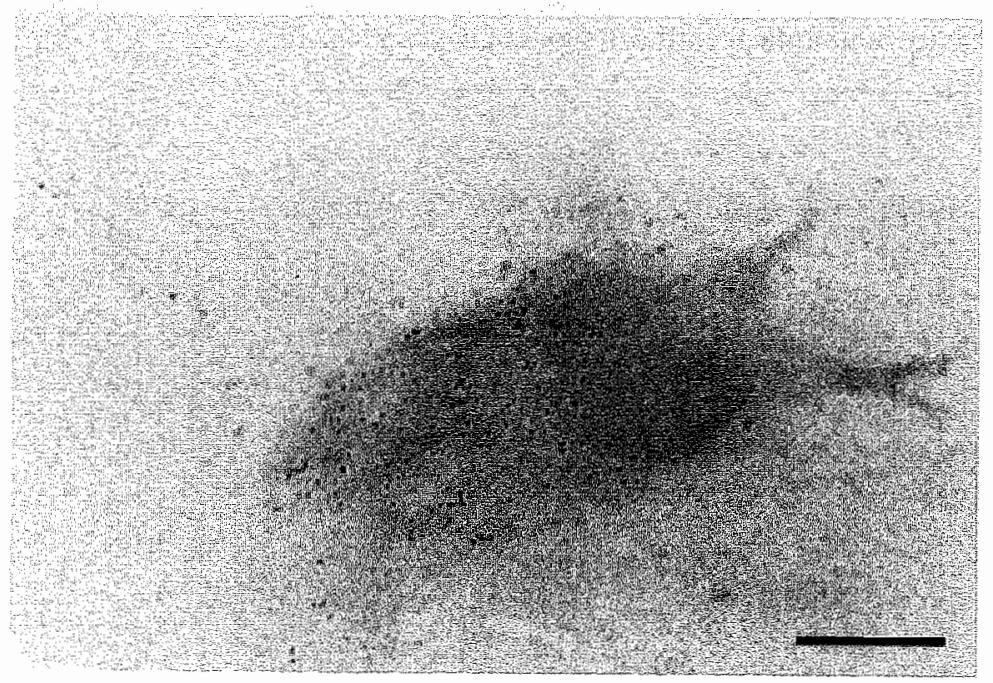

Figure 6. In siru hybridization of cultured human umbilical cord myofibroblasts on gelatin coated glass slides and hybridized with a type IV collagen cDNA probe. Scale bar $=10 \mu \mathrm{m}$.

tured cells showed strong labeling of the cytoplasm of the cultured cells (Fig 6), whereas in tissue sections in addition to the stromal cells some amniotic epithelial cells, smooth muscle cells and endothelial cells were labelled.

\subsection{Discussion}

Myofibroblasts are mesenchymal cells which share some characteristics of fibroblasts and smooth muscle cells. These cells show a well developed rough endoplasmic reticulum, nuclear indentations, myofilaments, pinocytotic vesicles, attachment bodies and rocal deposits of basement membrane components $(4,5)$. Myofibroblasts have an important function in wound healing (1). In granulation tissue and desmoplastic tissue reactions, this cell type is responsible for wound contraction and for the production of new "embryonal" type III collagen which is later replaced by type I collagen (16-18). The origin of the myofibroblast is still unclear. More specifically, the question arises whether these cells develop from a mesenchymal stem cell or alternatively are fibroblasts or smooth muscle cells in a specific functionally activated condition.

In order to shed more light on this question we studied the stromal cells of the umbilicall cord. This stroma is in direct continuity with that of the placental villi, which contains numerous myofibroblasts (19). From these findings it can be assumed that the stromal cells in the umbilical cord are myofibroblasts. We found by electron microscopy cells with an 
undulating nucleus with one or two nucleoli, fairly abundant focally dilated rough endoplasmic reticulum, peripheral bundles of microfilaments with dense bodies, attachment bodies and focal extracellular deposition of BM-like material.

In the cells the expression of BM components could be observed by immunohistochemistry and hybridocytochemical detection of mRNA for type IV collagen. Immunohistochemically, we could detect intra- and extracellular laminin and type IV collagen in tissue sections of umbilical cord as well as in vitro in monolayer or in collagen lattice cultures. Type IV collagen and laminin could furthermore be isolated from the tissue culture supernatant and in vitro abundant type IV collagen mRNA could be detected by in simu hybridization. This contrasted with skin fibroblasts, which did not produce any BM component. Pihlajaniemi et al. (13) used "normal" primary human fibroblasts as type IV collagen producing cells. This discrepancy might be explained by assuming that these cells, isolated as normal fibroblasts, can be activated in witro in such a way that they are capable to produce type IV collagen. Since we used the same probe as Pihlajaniemi et al. (13) it is tempting to speculate on a relationship between normal fibroblasts, identified by production of type I collagen and activated fibroblasts or myofibroblasts producing type IV collagen. Which factor causes this phenotypic shift has still to be investigated. These results prove that the stromal cells are not fibroblasts, although they share with fibroblasts the production of fibronectin and interstitial collagen types (I and III) as can be observed from the immunohistochemical results and as described by others (16-18).

The production of BM components could suggest that the stromal cells are smooth muscle cells. Smooth muscle cells usually express desmin, smooth muscle myosin and ax actin (2022) and these cytoskeletal proteins also occurred in the stromal cells. Two features, however, argue against the smooth muscle nature of the stromal cells. Firstly, they express fibronectin, which is not found in smooth muscle cells. Secondly, the BM was patchy and interrupted and the cells also produced interstitial collagens. Based upon these findings, we feel justified to conclude that the stromal cells of the umbilical cord are myofibroblasts. Our results demonstrate that these cells may express more phenotypic characteristics of smooth muscle cells $(20,21)$ than reported previously (23) (e.g. expression of smooth muscle myosin and $a$ actin). What the exact developmental relationship is between the different mesenchymal cells remains to be established.

Their role in the production of extracellular matrix, the regulation of contractile properties and their function in pathological processes, especially tissue repair and desmoplastic reaction in neoplasia, might be elucidated further in in vivo experiments.

\subsection{References}

1. Gabbiani $G$, Ryan GB, Majno $G$ : Presence of modified fibroblasts in granulation lissuc and possible role in wound contraction. Experientia 27, 549, 1971

2. Baur PS, Parks DH: The rnyolbroblast anchoring strand: the fibronectin connection in wound healing and the possible loci of collagen fobril assembly. I. Truma $23,853,1983$ 
3. Singer II, Kazazis DM, Kawka DW: Localization of the fibronexus al the surface of gramulation tissue myofibrolasts using doublemabel inmunogold electron microscopy on ultrathin sections. Eur 』 Cell Biol $38,94,1985$

4. L. Lipper \$, Kahn LB, Red dick RL. The myofibroblast. Pathol Annu $15,409,1980$

5. Seemayer TA, Lagace $\mathrm{R}$, scharch W, Theino WL: The myofibroblast: biologic, pathologic, and theoretical considerations. Pathol Annu 15, 443, 1980

6. Barsky $\$ H_{1}$ Copalakrishna $\mathrm{R}$ : Increased inwasion and spontaneov metastasis of BL6 melanoma with in hibition of the desmoplaztic response in C57 BL/6 mice. Cancer Res 47, 1663, 1987

7. Wu $\mathrm{KF}$. Pope $\mathrm{JH}$, Ellen $\mathrm{KA}$. Inhibition of growh of centain human tumour cell lines by a factor derived from human fibroblests-like cell lines. I. Demonstration by mixed culture and by use of cell washings. Int I Cancer $35,477,1985$

8. Bell E, rvarsson B, Merrill Ch: Production of a tissue-like structure by contraction of collagen latlices by human fibroblasts of different proliferative potential in vitro. Cell Biol 76, 1274, 1979

9. Nuggens $\mathrm{B}$, Merrill Ch, Lapiere Cla, Bell $\mathrm{E}$ : Collagen biosynthesis by cells in a tissue equivatom matrix in vitro. Collagen Rel Res 4, 351, 1984

10. Towbin H. Staehelin $\mathrm{Th}$, Gordon J: Electrophoretic transfer of proteins from polyacrylamide gels 10 nitrocellalose sheets: procedure and soms applications. Biochem $76,4350,1979$

11. Lacmmli UK: Cleavage of structural proteins during the assembly of the head of the bacteriophage T4. Nature $227,680,1970$

12. Schrier PI, Bernards R, Waessen RTMJ, Howweling A, van der Eb AJ: Expression of class I major histocompatibility antigens switched off by highly oncogenic adenovin 12 in transformed rat cells. Nature 305,771 , 1983

13. Pillajaniemi T, Tryggason K, Myers JC, Kurkinen M, Lebo R, Chüng M, Prockop DJ: cDNA clones coding for the pro $\alpha 1$ IV chain of human procollagen reveal an unusual homology of amino acid sequences in two halwes of the carboxyl-terminal domain. J Biol Chem 260,7681, 1985

14. Feinberg AP, Vogelstein B: A technique for radiolabeling DNA restriction endonuclease fragments to high specific activity. Anal Biochen 132,6, 1983

15. Feinberg AP, Vogelstein B: Addendum: a technique for radiolabeling DNA restriction endonuclease fragments to high specilic activity. Anal Biochen 137, 266, 1984

16. Seemayer TA, Schurch W, Lagace $R$ : Myofibroblasts in human pathology. Human Pathol 12, 491, 1981

17. Gabbiani G, Le Lous M, Bailey AJ, Bazin S, Delauney A: Collagen and myolibroblasts of granulation tissuce. A chemical, ultrastructural and immunological study. Virch Arch $[B] 21,133,1976$

18. Ligigee $R$, Grimad JA, Schuerch $W$, Seemayer TA: Myofibroblatic stromat reation in warcinoma af tha: threast: vatiations of collagenous matrix and structural glycopoteins. Virch Arch [A] 408, 49, 198 ,

19. Feller AC, Selmeider H, Schmidt D, Parwaresch MR: Mwofibroblast as a major celluar constiruent al vil. lous stronat in human placenta. Placenta $6,405,1985$

20. Tsukuda 'T', Tippens D, Gordon D, Ross R, Gown AM: HHF35, a muscle-actin-specific monoclonal antibody. 1. Immmocyochemical and biochemical characterization. Am 』 Pathol 126, 51, 1987

21. Tsukuda T, McNut! MA, Ross R, Gown AM: HHF35, a muscle aciin"specific monoclonal antibody. II. RCactivity in normal, reactive, and neoplastic human tissues. Am J Pathol 127, 389, 1987

22. Skalti $O$, Ropraz $P, T$ rzeciak A, Benzonana $G_{3}$ Gillessen, Gabbiani $G$ : $A$ monoclonal antibody against zzsmooth touscle actin: a new probe for sinooth muscle differentialion. I Cell Biol 103, 2787, 1986

23. Schiurch W, Seenayer TA, Lagace R, Gabbian G: The intermediate filament cyroskeleton of myofibroblasts: an immunofluorescence and ultrastructural study. Virch Arch $[A] 403,323,1984$ 


\section{Chapter 6}

\section{Origin of basement membrane type IV collagen in xenografted human epithelial tumor cell lines*}

*Cleutjens JPM, Havenith MG, Vallinga M, Beck C, ten Kate J, Bosman IFT.

Submitted for publication. 


\subsection{Introduction}

Basement membranes (BM), at the interface between epithelia and the underlying stroma, are composed of macromolecules such as type IV collagen $(1)$, laminin $(2,3)$ and heparan sulphate proteoglycan (4). Using specific antibodies to one or more of these constituents it has beer shown that in many carcinomas a discontinuous BM is deposited at the epithelialstromal interface. It has been suggested that the ability of cancer cells to form/degrade a BM may be associated with invasive and metastatic behaviour (5-10) and may be correlated with patient survival (11). It is generally assumed that epithelial BM are at least partly a product of the epithelial cells $(12,13)$. Several investigators have demonstrated that in witro epithelial tumor cells may continue to produce BM components (14-22). However evidence has been presented that mesenchymal cells are able to produce BM components and may therefore contribute to the formation of the BM. Kühl et al. (23) and Sanderson et al. (24) showed by cocultivation of mouse muscle fibroblasts and quail skeletal myoblasts, that the myoblast BM is of mouse origin. Similarly, combination of chick mesenchyme and rat endoderm resulted in formation of a BM of mesenchymal origin (25). However, experimental data concerning BM origin in neoplasms in vivo is very scanty. Recently, Damjanov et al. (26) studied the extracellular matrix of human tumor xenografts in nude mice using monoclonal anti-laminin antibodies, exclusively reactive with human laminin, and polyclonal anti-laminin antisera reaciing with human as well as with murine laminin. In many of their xenografts, tumoral BM laminin appeared to be of human as well as murine origin. They concluded that laminin in the extracellular matrix of xenografted lumors is at least partly of stromal origin. In this report we xenografted four human tumor cell lines into mude rats. Two of the cell lines did not produce (humany type IV collagen in vitro, whereas the other cell lines were able to produce type IV collagen. After xenografting, the production of type IV collagen was immunohistochemically investigated with ant bodies to human and host specific epitopes of type IV collagen, in order to gain insight in the possible contribution of epithelial and mesenchymal components in the assembly of type IV collagen molecules into a BM. In situ hybridization using a type IV collagen cDNA probe, recognizing human and mouse/rat type IV collagen mRNA, was used to investigate whether the observed immunohistochemical pattern correlates with the expression of mRNA coding for this protein.

\subsection{Materials and methods}

\subsubsection{Tissues}

Human cell lines derived from colonic adenocarcinoma (5583-E, HT-29), from transformed amniotic epithelium (WISH), and from an oral epidermoid carcinoma (KB) were used in this study. The characteristics of the 5583-E and HT-29 cell lines are described extensively elsewhere $(27,28)$. The WISH and KB cell lines were obtained from the Ameri- 
can Type Culture Collection (ATCC). The characteristies of these cell lines were reported by Hayflick and Eagle $(29,30)$. Cells were cultured in Dulbecco's modified Eagle's minimum essential medium (DMEM, Flow Laboratories, Amstelstad, Zwanenburg, The Netherlands) supplemented with $10 \%$ fetal calf serum (FCS, Boehringer, MAnnheim, FRG), before xenografting.

Human type I collagen was isolated from placenta as described elsewhere (31). Cells were cultured in or on human type I collagen lattices ( 1 or $2 \mathrm{mg}$ collagen/ml) as described by Nusgens (32). Lattices were sometimes populated with human skin fibroblasts, which contract the lattice within a few days. For histological evaluation the collagen lattices were processed as described for the tissue samples.

\subsubsection{Xenografting}

All tumor cell lines were xenografted in mude mice (NMRI nu/mu supplied by Zentral Institut für Versuchstiere, Hannover, FRG) and nude rats (CD 1 nu/nu supplied by Charles River, Sulzfeld, FRG) by injecting tumor cell suspensions $\left(1.5 \times 10^{6}\right.$ cells in $100-200 \mu \mathrm{l}$ PBS) subcutaneously. After a period of 2-6 weeks solid tumors of $0.5-1 \mathrm{~cm}$ in diameter were obtained.

Xenografts were removed and samples of the xenografts and the collagen lattice cultures were snap frozen in isopentane quenched in liquid nitrogen and stored at $-70^{\circ} \mathrm{C}$ and $/$ or fixed in $4 \%$ buffered formaldehyde and further embedded in paraffin.

\subsubsection{Antibodies}

Polyclonal cross-species reactive antisera were generated by immunization of rabbits with human type IV collagen isolated by pepsin digestion from human placenta as extensively described elsewhere (31). Monoclonal antibodies (1042 and 1043) were obtained after immunization with pepsin cleaved type IV collagen from human placenta (31). Monoclonal antibody 1043 is human specific, whereas 1042 reacts with human and rabbit type IV collagen (31). A polyclonal rabbit anti-mouse type IV collagen was kindly provided by Dr. M. Demarchez and Dr. D.J. Hartmann (33). This antibody was adsorbed several times with human type IV collagen, and was used in a 1:1000-1:2000 dilution.

Mouse monoclonal anti-human type VII collagen (NP76) was kindly donated by Dr. R. Burgeson. This antibody is human specific and reacts only with the epithelial BM of epidermis, trachea and oesophagus (34). Mouse monoclonal anti-human laminin (4E10) (35), is human specific and reacts with all BM. Rabbit polyclonal anti-mouse laminin obtained after immunizing rabbits with mouse EHS laminin (E/Y Laboratories, Sanbio, Uden, The Netherlands), is reactive with all BM. This polyclonal antiserum is cross-species specific and does not react with type IV collagen or fibronectin on dot-blots and western-blots. The characteristics and source of the antibodies are extensively specified in chapter 9.4. 


\subsubsection{Immunoblotting of culture supernatants}

Supernatants of 5583-E, HT-29, WISH and KB cells were precipitated with $4 \mathrm{M} \mathrm{NaCl}$, dissolved in and dialyzed against SDS-sample buffer and run on a 5\% SDS-polyacrylamide ge! (36), followed by blotting onto nitrocellulose membrane (37) as described in chapter 9.5 . The nitrocellulose filters were washed ( 3 times $10 \mathrm{~min}$ ) with PBS and $0.05 \%$ Tween 20 , and subsequently stained as described under immunohistochemistry (chapter 9.2).

\subsubsection{Immunohistochemistry}

In order to expose the antigenic sites, for all antigens paraffin tissue sections were pretreated with pronase (Boehringer, Mannheim, FRG) when monoclonal antibodies were applied, or with pepsin (Boehringer, Mannheim, FRG) for the polyclonal antisera. On frozen sections the antibodies could be employed without enzymatic pretreatment. Sections were incubated for one hour with the primary antibodies and subsequently with peroxidase labeled rabbit anti-mouse IgG or peroxidase labeled goat anti-rabbit IgG (Dakopatts, Glostrup, Denmark) for the monoclonal and polyclonal antibodies respectively. After each incubation, sections were washed with PBS ( $3 \times 5 \mathrm{~min})$. Immunoreactive sites were visualized with diaminobenzidine. Finally, the sections were lightly counterstained with hematoxylin as described in chapter 9.2 and 9.3.

\subsubsection{In situ hybridization}

$4 \mu \mathrm{m}$ frozen sections were mounted on RNase free coated slides, fixed with freshly prepared $4 \%$ paraformaldehyde and washed with PBS, baked, washed again and treated with Triton $X-100$. After washing in PBS the sections were incubated with proteinase $K$ in a buffer containing Tris and EDTA. The sections were fixed again with $4 \%$ buffered paraformaldehyde, washed with PBS and treated with acetic anhydride in triethanolamine and furthermore incubated with formamide in $2 x$ SSC ${ }^{35}$ S-dCTP labeled type IV collagen probe (38) was prepared according to the random primed labeling method using a Boehringer labeling kit $(43,44) .15 \mu$ probe/hybridization mixture containing $300,000 \mathrm{cpm}$ was applied to each section. The sections were subsequently covered with $22 \times 22 \mathrm{~mm}$ siliconized coverslips and sealed with rubber cement. Hybridization mixture contained yeast t-RNA, salmon sperm DNA, deionized formamide, Tris-HCl, NaCl, EDTA, Denhardt's mixture, Dextran sulphate, and DTT. After $12-16 \mathrm{~h}$ incubation at $50^{\circ} \mathrm{C}$, the coverslips were removed and the sections were washed with SSC. Following these steps the sections were dehydrated in graded series of ethanol, air dried and coated with Kodak NTB-2 nuclear track emulsion and exposed for various periods of time. The exposed slides were developed in 1:1 Kodak D-19 developer, fixed, and counterstained with hematoxylin, dehydrated and mounted. Parallel sections were hybridized with an ${ }^{35} \mathrm{~S}$ labeled emply plasmid as a negative control. This method is extensively described in chapter 9.7 . 


\subsection{Results}

\subsubsection{Antibody specificity}

By ELISA the polyclonal anti-human type IV collagen antisenum did not react with types I and III collagen and showed only a slight reaction with type $V$ collagen (Fig 1A). After solid phase immunoadsorption with type IV collagen, the antiserum only detected type IV collagen. Reactivity with type I, II and V collagen could not be detected with the monoclonal antibodies (Fig $1 \mathrm{~B}+\mathrm{C}$ ). In immunoelectroblotting experiments the polyclonal antiserum showed immunoreactivity with several reduced and non-reduced type IV collagen bands, in the same pattern as the Aurodye stain of the reduced and non-reduced type IV collagen (Fig 2 lanes 2-5). However, the monoclonal antibodies both showed immunoreactivity with a single band in the high molecular region of mon-recluced type IV collagen and very weak immunoreactivity with a single band in the low molecular weight region (Fig 2 lanes 6-9).

Immunohistochemical experiments further substantiated the specificity of these antibodies. On a wide variety of human tissues both polyclonal and monoclonal anti-type IV collagen antibodies reacted exclusively with $\mathrm{BM}$ in an identical pattern. On sections of normal tissues from various other species (including $\mathrm{Balb} / \mathrm{c}$ and $\mathrm{NMRI} \mathrm{nu} / \mathrm{nu}$ mice or rats) polyclonal anti-type IV collagen antisera showed a similar pattern of reactivity.

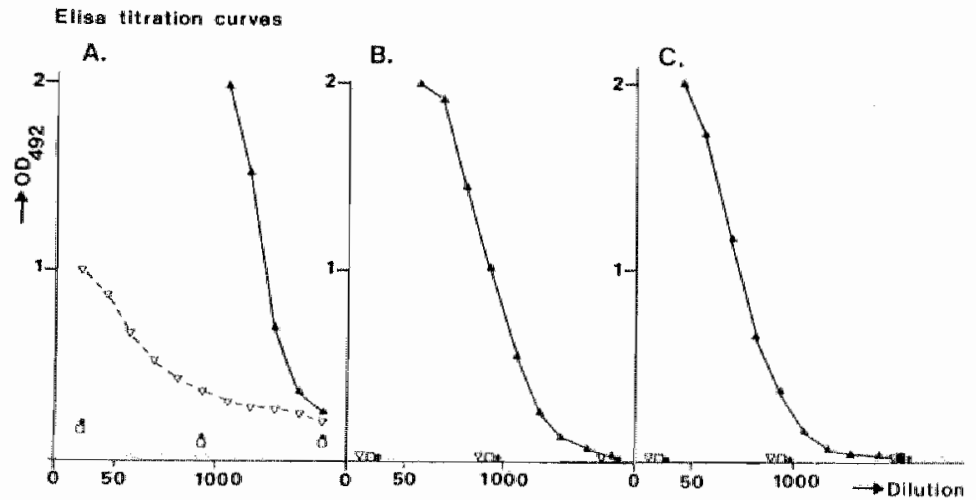

Figure 1. ELISA resting of reactivity of anti-type IV collagen antibodies with:

- human type I collagen

- baman type illi collagen

- human type TV collagen

$\nabla$ human type $V$ collagen

A. rabbit polyclonal anti-type lV antiserum

B. 1042, mouse monocllonal anti-human type IV collagen antibody

C. 1043, mouse monoclonal anti-human type IV collagen antibody 


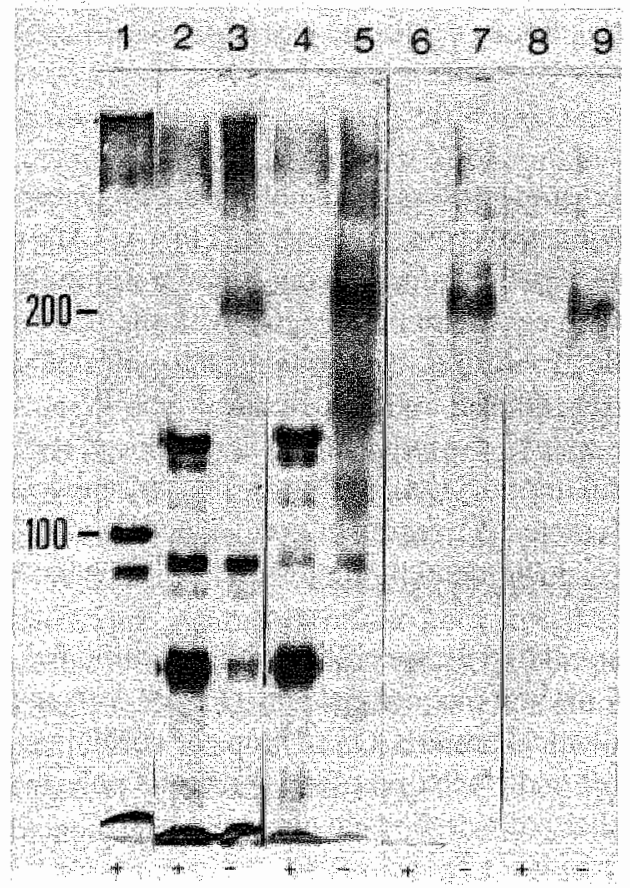

Figure 2. Western blot of SDS-PACE separated collagens. Lane 1: reduced human rype I collagen stained with A urodye. Lane 2 and 3: reduced and non-reduced tuman type IV collagen stained with Aurodye. Lane 4 and 5: reduced and non-reduced human type IV collagen reacted with polyclonal anti-human type IV collagen. Lane 6 and 7: reduced and non-reduced human type IV collagen reacted with monoclonal 1042. Lane 8 and 9: reduced and non reduced human type IV collagen reacted with monoclonal 1043

The two monoclonal anti-type IV collagen antibodies, however, did not show any reactivity with tissues from these species. The polyclonal antiserum to mouse type IV collagen, absorbed with human type IV collagen, was not reactive with BM on frozen sections of human tissues, but showed intense immunoreactivity with BM in mouse tissues (Fig 3). The polyclonal anti-mouse type IV collagen antiserum was also reactive with BM in rat tissues in a pattern identical to that of the cross-species reactive polyclonal anti-human type IV collagen antiserum, as described above.

\subsubsection{Type IV collagen detection in cancer cell lines}

I mmunohistochemical studies of 5583-E or HT-29 cells grown in artificial collagen lattices did not reveal reactivity with any of the polyclonal or monoclonal anti-type IV collagen antibodies. 

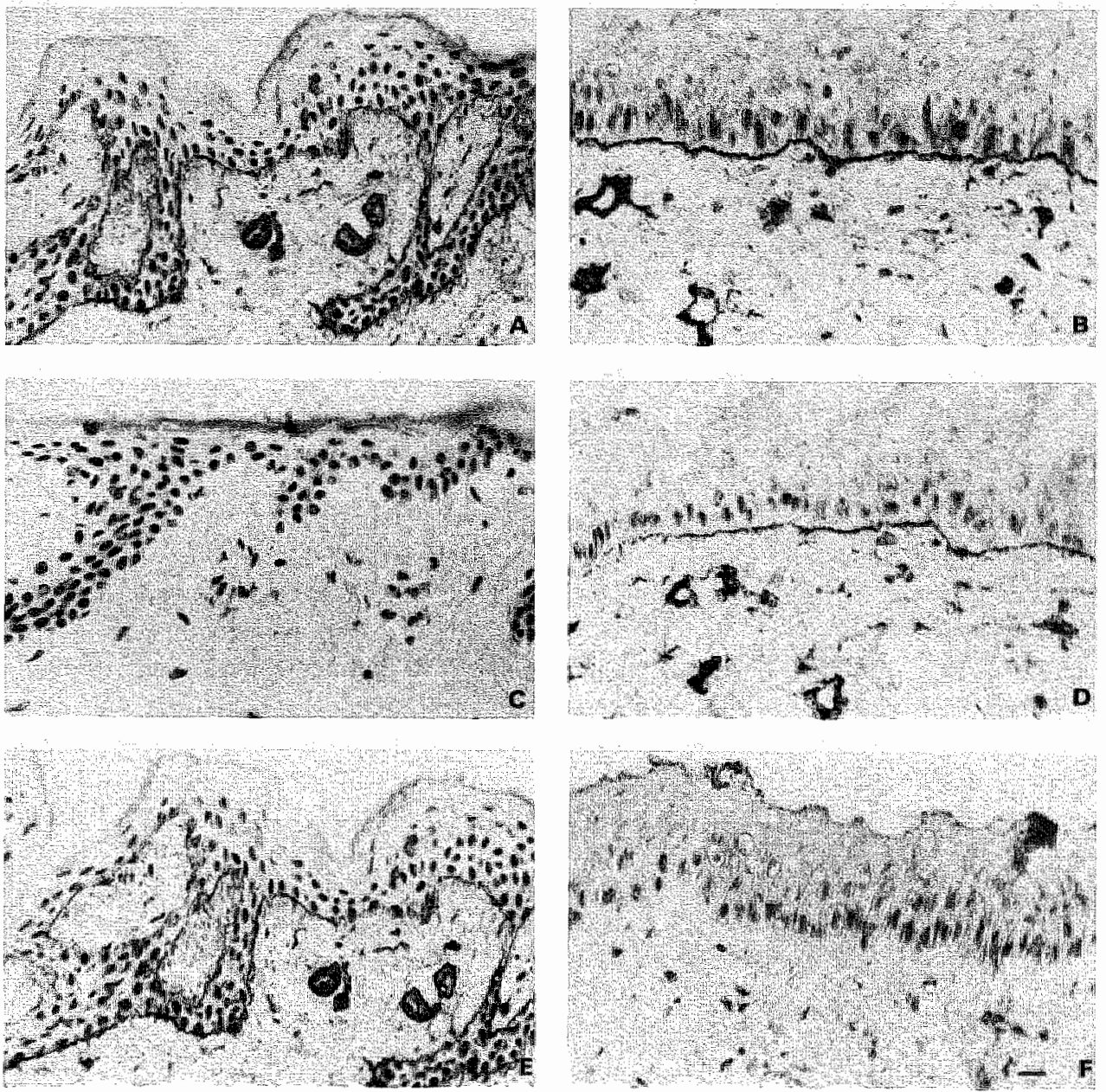

Figure 3. Immunoreactivity on frozen sections from human skin $(A, C, E)$ and rat skin $(B, D, f)$ with: polyclonal anti-human type IV collagen antiserum $(A, B)$, polyclonal anti-mouse type IV collagen antiserum $(C, D)$, monodonal (1042) anti-human type IV collagen antibody (E, F). Scale bar $=10 \mu \mathrm{m}$. 

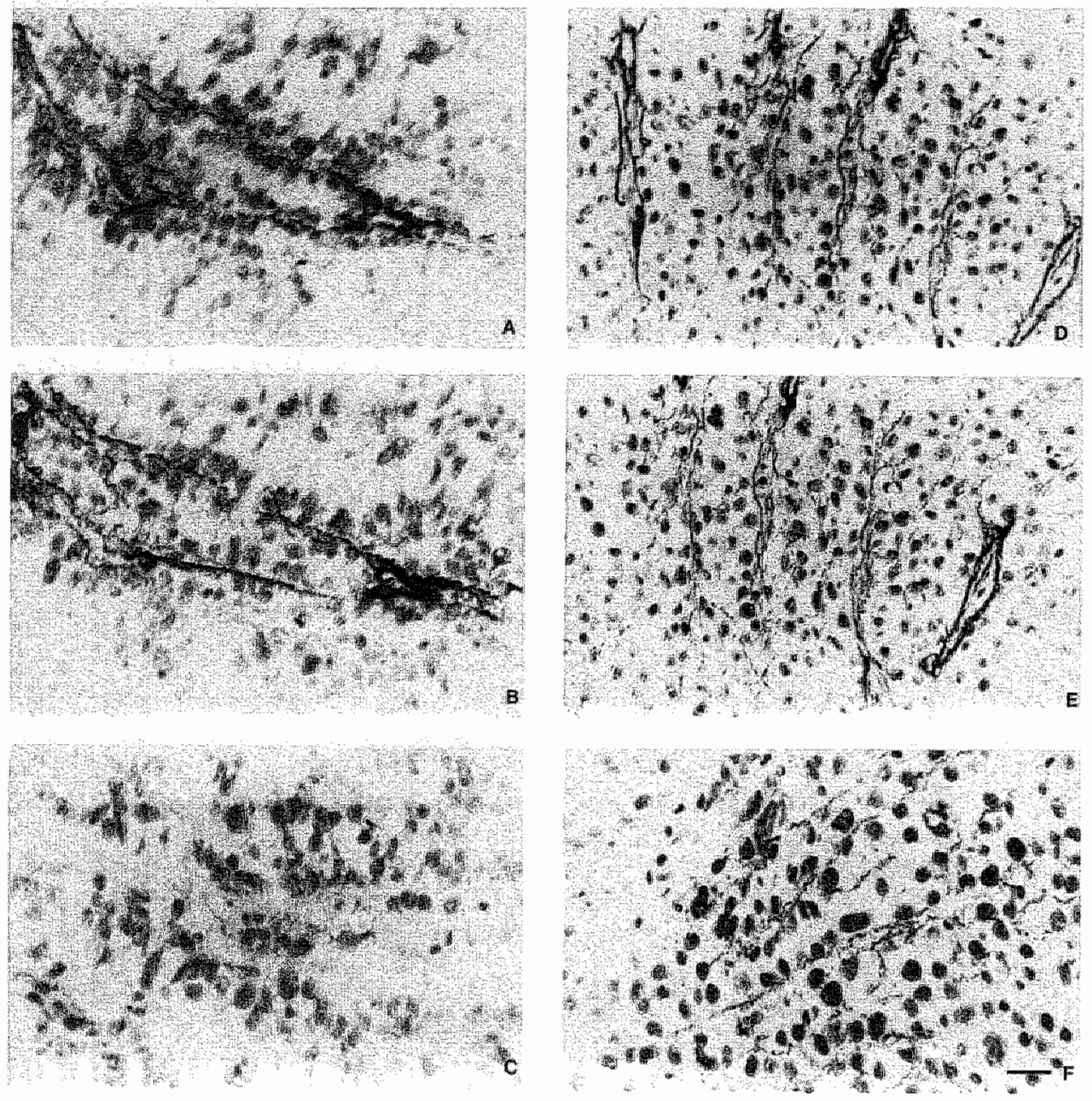

Figure 4. Frozen scetions of rat xenografts of tumor cell-line 5583 $E\left(A_{y}, B, C\right)$ and $K B(D, E, F)$ (immunoperowidase).

A and D: cross species reactive polyclonal antiserum to type IV collagen.

$B$ and $E$ : mouse and rat specitic polyclonal antiserum to type IV collagen.

$C$ and F: human specific monoclonal antibody to type IV collagen (MA 1042).

Scale bar $=10 \mu \mathrm{m}$ 
On immunoblots of precipitated tissue culture supernatants of 5583-E and HT-29 immunoreactivity with antibodies to type IV collagen did not occur. In contrast, pro a 1- and pro 2-chains of type IV collagen were detected in supernatants of WISH and KB cell lines. WISH and $\mathrm{KB}$ cells, cultured in collagen lattices, showed extensive gramular intracytoplasmic and/or pericellular immunoreactivity for type IV collagen with polyclonal as well as monoclonal anti-type IV collagen antibodies. However, BM like structures could not be identified (chapter 7 ).

\subsubsection{Type IV collagen detection in xenografts}

Rat xenografts were used for immunohistochemistry in order to avoid background staining when using mouse monoclonal antibodies on mouse tissues in an indirect peroxidase technique.

In xenografts of 5583-E and HT-29 cells immunohistochemical studies with cross-species reactive polyclonal anti-buman type IV collagen antiserum showed reactivity with epithelial as well as vascular BM (Table 1). The epithelial BM were irregular and discontinuous, with many tumor cell nests lacking a BM altogether. In 5583-E and HT-29 xenografts, however, both monoclonal antibodies did not show any reactivity for type IV collagen (Fig 4). Using the polyclonal anti-mouse type IV collagen, however, the staining pattern was identical with the cross-species reactive polyclonal antiserum.

Table 1. Immunoreactivity and in situ hybridization on frozen sections of xenotransplanted tumor cell lines

\begin{tabular}{|c|c|c|c|c|c|c|c|}
\hline \multirow[b]{2}{*}{ cell line } & \multicolumn{3}{|c|}{ anti-type IV collagen } & \multicolumn{2}{|c|}{ anti-laminin } & \multicolumn{2}{|c|}{ in situ hybridization } \\
\hline & $\begin{array}{l}\text { pa } \\
\text { cross }\end{array}$ & $\begin{array}{l}\text { pa } \\
\text { mouse/rat }\end{array}$ & $\begin{array}{l}\text { ma } \\
\text { hum }\end{array}$ & $\begin{array}{l}\text { ma } \\
\text { hum }\end{array}$ & $\begin{array}{l}\mathrm{pa} \\
\text { cross }\end{array}$ & stroma & cells \\
\hline $5583-\mathrm{E}$ & + & + & - & - & + & + & - \\
\hline $\mathrm{HT}-29$ & + & + & - & - & + & 4 & - \\
\hline $\mathrm{KB}$ & + & + & + & 4 & + & + & + \\
\hline WISH & 4 & + & + & 4 & + & + & + \\
\hline
\end{tabular}

hum = human specific; cross = cross species reactive; mouse/tat = mouse/rat specific; cells = tumor culls; ma $=$ monoclonal; $\mathrm{pa}=$ polyclonal 
Using the monoclonal antibody to laminin no BM staining was observed, whereas BM-like structures could be visualized using the cross-species reactive polyclonal antiserum. No reactivity was observed using the monoclonal antibody to type VII collagen. In WISH and $K B$ xenografts reactivity for type IV collagen with the monoclonal antibodies in a BM pattern could be demonstrated dearly (Fig 4 ).
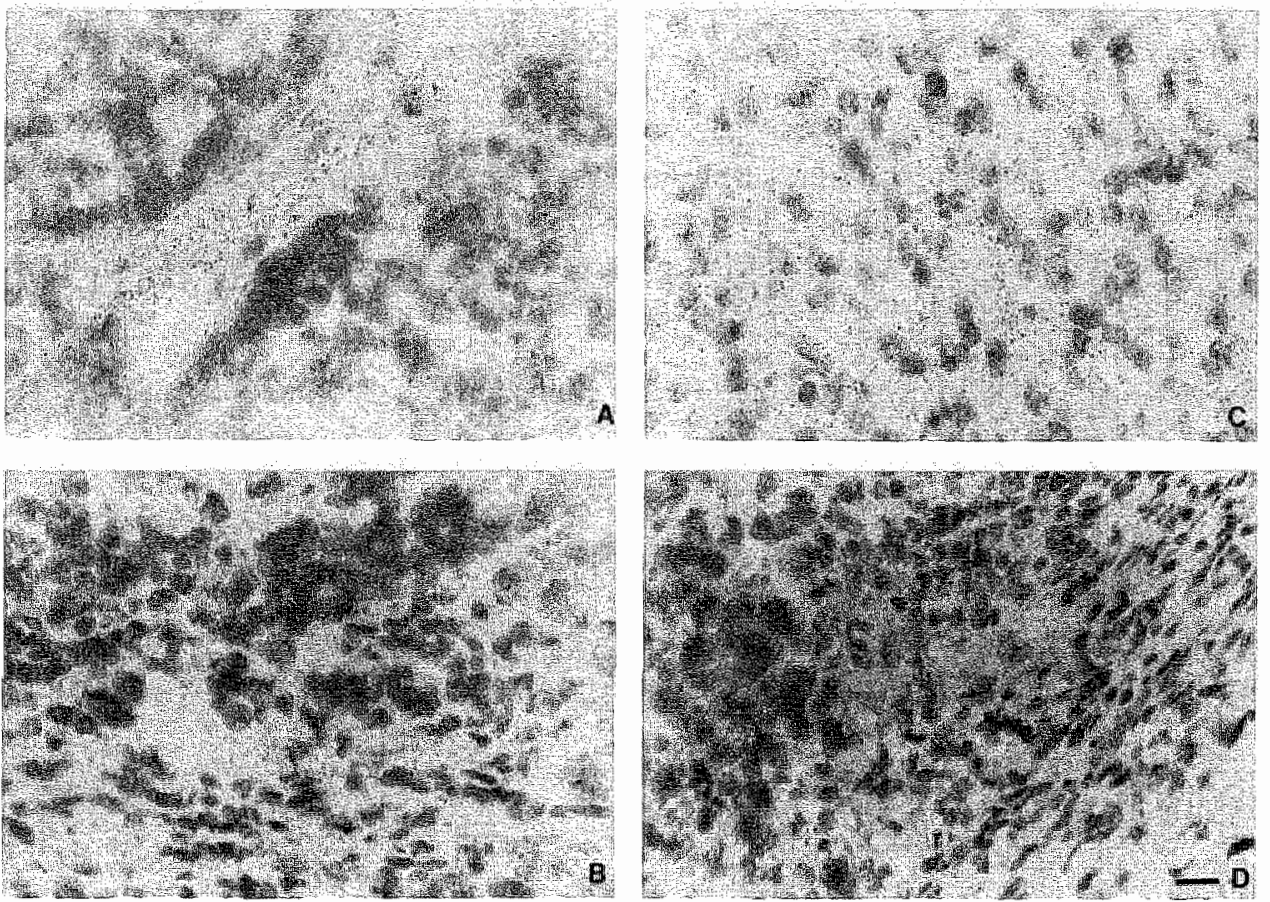

Figure 5. la sint hybridization on frozen sections of rat xenografts of tumor cell line $5583(\mathrm{~A}, \mathrm{~B})$ and $\mathrm{KB}(\mathrm{C}, \mathrm{D})$ with a type $I V$ collagen cDNA probe.

A anci C hybridized will a type IV collagen cDNA probe.

$B$ and $D$; negative control, hybridized with a labeled empty plasmid.

Scale bar $=10 \mu \mathrm{m}$. 
Not only human specific type IV collagen but also human laminin and type VIl collagen could be demonstrated in these xenografts. BM of vascular structures in the xenografts did not react with the monoclonal anti-type IV collagen antibodies.

The polyclonal antiserum specific for mouse/rat type IV collagen and the cross-species reactive anti-human type IV collagen antiserum showed identical staining in all the xenografts. These antibodies also stained the BM of blood vessels, Schwann cells, muscle cells and fat cells.

\subsubsection{In situ hybridization}

The results of our in situ hybridization experiments are summarized in Table 1 . Using a type IV collagen cDNA probe in in situ hybridization experiments on frozen sections of the xenotransplants of 5583-E and HT-29, we observed an intense hybridization reaction with the host stromal cells adjacent to the human tumor cells, but not with the tumor cells (Fig 5).

Experiments on frozen sections of $\mathrm{KB}$ and WISH xenotransplants showed a slight but distinct hybridization reaction with tumor cells and also with stromal cells (Fig 5). The used cDNA probe also recognized rat type IV collagen mRNA, because in all xenografts labeling was noticed of basal cells of the rat epidermis and also of some mesenchymal cells of the dermis adjacent to the epidermal BM or surrounding the xenografted tumor cells (Fig $6)$.

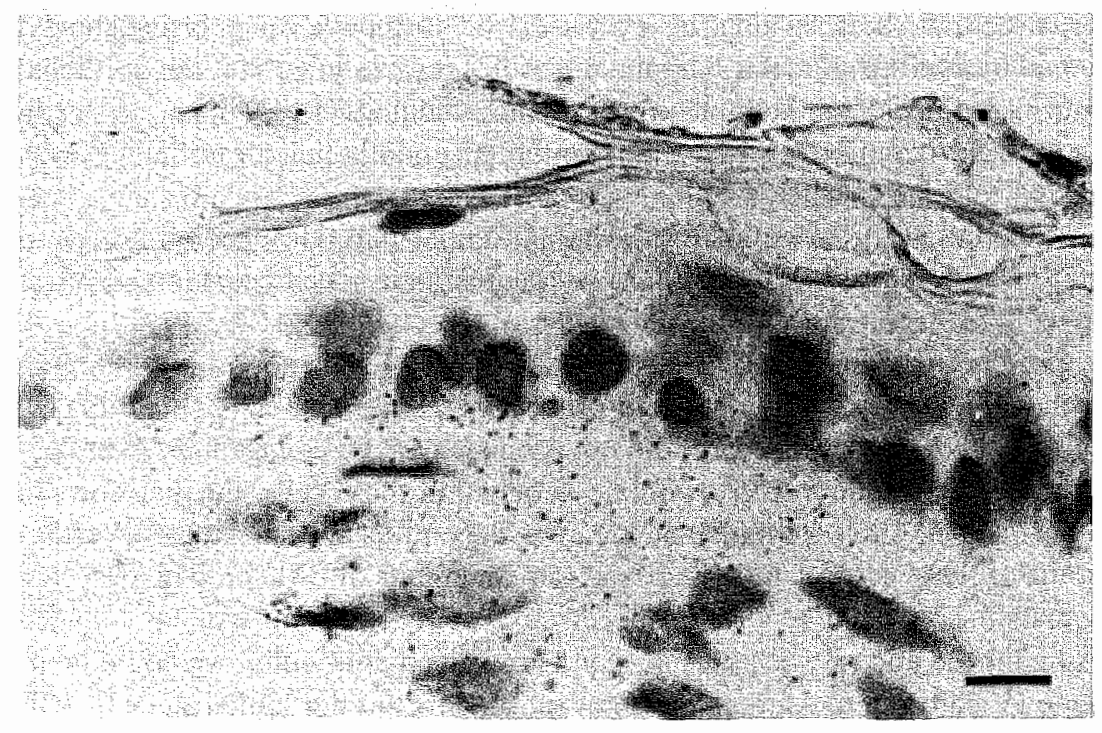

Figure 6. In situ hybridization on a frozen section of at epidermis with a type IV collagen cDNA probe. Scale bar $=10 \mu \mathrm{m}$. 


\subsection{Discussion}

In xenografts of human tumor cell lines in mude mice or rats the interaction ir wivo between neoplastic epithelial cells and mesenchymal stromal elements can be investigated. For example, the origin of the BM can be traced when antibodies which discriminate between human and murine BM compontents are employed in immunohistochemical studies. Using this approach Holmstrup (40) studied the immunophenotype of laminin and type IV collagen in BM of normal human oral mucosa, transplanted into nude mice. He found that species cross-reactive polyclonal antisera against laminin and type IV collagen reacted equally well with vascular and epithelial BM whereas human specific monoclonal antibodies reacted intensely with vascular BM but only weakly or not at all with epithelial BM. Holmstrup concluded that under these conditions oral mucosal cells participate in the deposition of BM at the epithelial/stromal interface and that the vascular supply of the transplant is of mixed human and murine origin.

Demarchez et al. (33) studied revascularization of human skin transplants in nude mice, applying murine and human specific anti-type IV collagen antibodies and anti-HLA-DR antibodies, to identify the origin of the BM and vascular endothelium respectively. They found a shift from human to murine endothelium and a subsequent change from human to mouse type IV' collagen in the subendothelial BM. Kühl et al. (23) cocultured mouse myoblasts with chicken fibroblasts and found deposition of chicken type IV collagen in the BM around mouse myoblasts. Damjanov et al. (26) xenografted a lung adenocarcinoma and a yolk sac carcinoma, both producing laminin in vitro, and a hepatoblastomat and a hepatocellular carcinoma, both lacking this characteristic, into nude mice. Using species cross-reactive and human specific anti-laminin antibodies it was shown that the epithelial $\mathrm{BM}$ were of murine or mixed human/murine origin. These findings clearly illustrate that in the deposition of BM surrounding single cells or epithelial, endothelial, mesothelial sheets interstitial stromal cells may participate.

In this context we studlied the origin of BM in human tumor cell lines, xenografted into nude mice and rats, using species cross-reactive as well as human specific and mouse or rat specific anti-type IV collager antibodies.

To this end we used two cell lines which do and two cell lines which do not produce laminin and type IV collagen in vitro. The human colon cancer cell lines 5583-E (27) and HT-29 (28) in immunohistochemical experiments did not produce type IV collagen. By in situ hybridization no type IV collagen mRNA could be detected in these cells. Furthermore, in immunoblots of tissue culture supernatants type IV collagen was not detected. Nevertheless, in xenografts of these cells in nude mice and rats fragments of $\mathrm{BM}$ could be detected by immunohistochemistry, using a polyclonal species cross-reactive anti-iype IV collagen antiserum. Using mouse and rat specific anti-type IV collagen antibodies, we could demonstrate the type IV collagen to contain mouse or rat specific but not human specific epitopes. Furthermore we could demonstrate type IV collagen mRNA in the stromal cells but not in the (xenografted) carcinoma cells. These findings prove that type IV collagen in the epithelial BM in xenografts of 5583-E and HT-29 cells is deposited by stromal cells. 
Two other cell lines, $\mathrm{KB}$ (derived from a human squamous cell carcinoma) (30), and WISH (derived from in vitro transformed amnion epithelium) (29), in witro produced type IV collagen (39). By immunohistochemistry intracytoplasmic type IV collagen immunoreactivity could be detected and by immunoblotting this BM component could be identified in the issue culture supernatant. Furthermore by in situ hybridization we could detect type IV collagen mRNA in these cells. When xenografted into nude mice and rats these cell lines gave rise to tumors with extensive BM deposition. In these BM human as well as murine type IV collagen epitopes could be detected by immunohistochemistry. Furthermore, in situ hybridization using a type IV collagen CDNA probe (38) demonstrated type IV collagen mRNA in the epithelial and in the stromal cells. In these xenografts, therefore, the epithelial BM contained components derived from the epithelial cells as well as from stromal cells.

In situ hybriclization experiments on rat skin using the type IV collagen cDNA probe showed that type IV collagen mRNA is present in the basal cells of the epidermis as well as in the underlying dermal cellis. This observation suggests that normal epithelial BM may be also composed of epithelial and stromal components. Type JV collagen probes discriminating between human and rat type IV collagen (mRNA) might elucidate these findings observed in these xenografts, and additionally could give answer to the questions concerning turnover and expression rates of the different type IV collagen molecules.

Which stromal cells could be responsible for the production of the epithelial BM components? Additional experiments in neoplasms and in normal tissues are necessary to resolve this question. It is tempting to speculate, however, that myolibroblasts are involved. Myofibroblasts play an important role in tissue repair and the desmoplastic tissue response (41, 42) and are capable to produce a variety of BM components. Furthermore, in neoplasms often a desmoplastic reaction can be observed which consists largely of myofibroblasts which deposit large amounts of BM material in the extracellular matrix.

In conclusion, our results demonstrate that in immune-deficient mice or rats the BM surrounding the xenografted human cancer cells is (partly) derived from murine/rat and therefore stromal cells and partly tumor cell derived. It is suggested that in this situation but probably also in normal BM stromal myofibroblasts participate in the deposition of the $\mathrm{BM}$ at the epithelial/mesenchymal transition.

\subsection{Reterences}

1. Kefalides NA, Alper R, Clark CC: Biochemistry and metabolism of basement membranes. Int Rov Cylol $61,167,1979$

2. Foidar IM, Bere EW, Yaar M, Remard SI, Guillino M, Martin GR, Katz SL: Distribution and immuno-elce. tron microscopic localization of laminin a noncollagenous basement nembrane glycoprotein. L.ab Irwes $42,330,1.980$

3. Timpl R, Rohde $H$, Robey $P G$, Rennard SI, Foidart JM, Martin GR: Laminin - a glyooprotein from basc men membranes. J Buol Chem 254,9933, 1979

4. Hacsel JR, Robey PG, Barrach HJ, Wilcek J, Rennard SL, Martin GR: Isolation of a heparan-sulphate con. laining proteogiycan from basement membrane. Proc Natl Acad Sci USA 77, 4494, 1980 


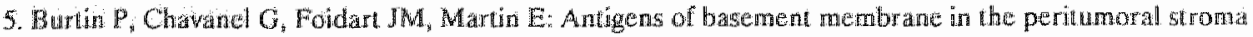
in human colonic adenocarcinomas an irnmonofuorescence study. In J Cancer $30,13,1982$

6. Gould VE, Battifora $H$ : Origin and signilicance of the basal lanwa and some interstital filbrillar components in epithelial neoplasms. Pathol Annu 11, 353, 1976

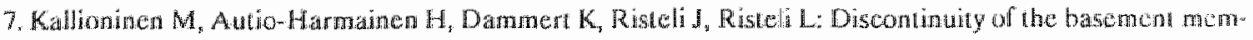
brane in librosing brtocelluar carcinomas and baso squamous carchomas of the skin: an immumhistochemical stady with human Iaminin and type IV collagen antibodies. J Invest Dermatol $82,248,1984$

8. Liota LA, Rao CN, Barsky $\$$ H. Tumor invaston and the extracellular matrix Lab Lnvest 49,636, 1983

9. Mcmrdle JP, Muller HK, Roff BT, Murphy WH: Basal hamina redevelopment in tumours metastatio to brain: an immunoperoxidase study using an antibody to type IV collagen. Int J Cancer 34, 633, 1984

10. Terrianowa $V P$, Willams JE, Liota LA, Martin $R$ : Modulation of the metastatic activity of melanoma cells by laminin and fibronectin. Science $226,982,1984$

11. Forster SJ, Talbot IC, Gritchley DR: Laminin and fibronectin in rectal adenocarcinomas: relationship to tumour grade, stage and metastasis. Br J Cancer $50,51,1984$

12. Banerje SD, Cohn RH, Bernticld MR: Basal lamina of embryonic salivary epithelium: production by the epithelium and role in maintaining lobular morphology. J Cell Biol 73, 445, 1977

13. Dodson W, Hay ED: Secretion of collagenous stroma by isolated epithelium grown in vitro. Exp Cell Res $65,215,1971$

14. Alitalo $K$, Vaheri $A$, Krieg Th, Timpl R: Biosynthesis of two subunits of type VV procollagen and of oher basement membrane proteins by a human tumor cell line. Eur J Biochem 109, 247, 1980

15. Brownell $\mathrm{AO}$, Bessen $\mathrm{CC}$, Slavkin $\mathrm{HC}$ : Possible lunctions of mesenchyme cell-clerived fibronecin during formation of basal lamina, Dev Biol 78, 3711, 1981

16. David $G$, Bernfield $M$ : Collagen reduces glycosanninoglycan degradation by cultured mammary epilhcthial colls: Possible mechan for for basal lamina formation. Froc Natl Acad Sci USA 76, 786, 1979

17. David $G$, Bernfield $M$ : Type collagen reduces the degradation of basal lamina protenglycan by marmmary epithelial cells I Cell biol $91,281,1981$

18. Emerman T, Pitelka DR: Maintenance and induction of morphological differentiation in dissociated manmary epithelium on floating collagen mernbranes. In Vittro 13, 316, 1977

19. Garbi C, Wollman SH: Basal lamina formation on thyroid epithelia in separated follicles in suspension culture. J Cell Biol 94, 489, 1982

20. Heatheote $\mathrm{G}$, Bruns $\mathrm{RR}$, Orkin $\mathrm{RW}$ : Biosynthesis of sulphated macromolecules by rababit lens epitheliun. Ir. Relationship to basement menzbrane formation. J Cell biol 99, 861, 1984

21. Hornung J, Bohnert $A$, Phan-Than $L$, Krieg T, Fusenig NE: Basement membrane formation by malignant mouse keratinocyte cell lines in organotypic culture and transplants: corretation with degree of morphologic differentiation. J Cancer Res Clin Oncol 113, 325, 1987

22. Searpas, Modesti A. Triche TJ: Extracellular matrix synthesis by undifferentiated childhood tumor cell lincs. And Pathol 129,74, 1987

23. Kuhl U, Oealan M, Timpl $\mathbf{R}_{n}$ Mayne R, Hay $\mathbf{E}$, von der Mark K. Role of muscle fibroblast in the depasition of tyoe IV collagen in the basal lamina of myotubes. Differentiation $28,164,1984$

24. Sanderson RD, Fitch JM, Linsenmayer "TR, Mayne R: Fibroblasts promote the formation of a continucus batsal lamina during myogenesis in vitro. 1 Cell Biol 102,740 , 1986

25. Simon-Assmann $\mathbb{P}$, Bouziges $\mathbb{F}$, Arnold $C_{n}$ Haffen $K$, Kedinger $M$ : Epithehal-mesenehymal incractions in the production of basement menbrane components in the gut. Development 102, 339, 1988

26. Damjanov L, Damjanov $N$ Knowless BB, Engyall E: Osugin of leminin in the extracellalar matrix of human fumor xenografts in nude mice. Virch Arch [B] 49, 45, 1985 
27. Versijnen CPHJ, Arends WW, Moerkerk PTM, Geraeds IPM, Uitendal MP, Bosman FT: The tastab. lishment and characterization of two new cell linas derived from a single human colonic adenocat cinoma. Virch Arch [B] 53, 191, 198 ]

28. Fogly J, Trempe G: New tumor cell lines. In: Human tumor cells "in vituro". Fogh J, ex. Plenum press, New York. 115, 1975

29. Hayflick L: The establishment of a line (WISH) of human amaion cells in continuous cultivation. Exp Coll Res 23, 14, 1961

30. Eagle H: Propagation in a fluid medium of human epidermoid carcinoma strain KB. Proc Soc Exp Biol (N.Y.) $89,362,1955$

31. Havenith MG, Clentjens JPM, Beek C, v.d. Linden JE, De Goeij AFPM, Bosman FT: Human specific antitype IV collagen monoclonal antibodies, characterization and application to immunohistochemistry. Histochemistry $87,123,1987$

32. Nusgens $B$, Merrill $C$, Lapiere $C, B$ ell $E$ : Collagen biosynthesis by cells in a tissue equiwalent matrix in vittro. Collagen Rel Res 4, 351, 1984

33. Demarchez M, Hartmann DJ, Prunieras M: An immunohistochemical study of the revascularization process in human skin transplanted onto nude monse. Transplantation 43,896, 1987

34. Sakai L, Keene D, Morris N, Burgeson R: Type VII collagen is a major structural component of anchoring. fibrills, J Cell Biol 103, 1577, 1986

35. Wewer $U$, Albrechtsen $R$, Manthorpe $M$, Varon $S$, Engvall $E$, Ruoslahti E: Human laminin isolated in a nearly intact, biologically active form from placenta by limited protcolysis. J Biol Chem 258, 12654, 1983

36. Laemmli UK: Cleavage of structural proteins during the assembly of the the ad of the bacteriophage "T. NatLurc 227,680, 1970

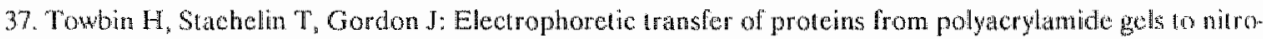
cellulose sheets: procedure and some applications, Proc Natl Acad Sci USA 76, 4350, 1979

38. Pihlajaniemi $T$, Tryggvason $K$, Myers JC, Kurkinen M, Lebo R, Ching M, Prockop DJ: cDNA cloncs coding for the pro wl IV chain of human procollagen reveal an unusual homology of anino acid sequences in two halves of the carboxyl-terminal domain. J Biol Chem 260, 7681, 1985

39. Cleutjens JPM, Vallinga M, Havenith $\mathrm{MG}_{2}$ Ten Kate J, Bosman FT: In vitro production and deposition of basement nembrane components. Submitted

40. Holmstrup P: Studies on the deposition of laminin and type IV collagen in human oral mucosa transplanted to rude mice. Acta Pathol Micrabiol Immunol Scand Sect A $93,1,1985$

41. Seemayer TA, Lagace R, Schürch W, Thelmo WL: The myafibroblast: biologic, parhologic, and theoretical considerations. Pathol Annu 15, 443, 1980

42. Lipper S, Kahn LB, Reddick RL: The myohbobliast. Pathol Annu 15,409, 1980

43. Feinberg AP, Vogelstein B: A technigue for radiolabeling DNA restriction endonuclease fragments to high specific activily. Anal Biochem $132,6,1983$

44. Feinberg AP, Vogelstein B: Addendum: a technique for radiolabeling DNA restriction endontuclease frag. ments to high specific activity. Anal Biochem 137, 260, 1984 



\section{Chapter 7}

\section{In vitro production and deposition of basement membrane components*}

* Cleutjens IPM, Vallinga M, Beek C, Bosman FT.

Submitted for publication. 


\section{1 introduction}

The basement membrane (BM) is a specialized domain of the extracelhular matrix, which connects epithelial cells with the underlying or surrounding interstitium (1). A type IV collagen lattice provides the basic structure of all BM. The only exception is the central corneal epithelium, where a type IV collagen lattice does not occur at the epithelial/stromal interiface (2).

It is ge nerally accepted that BM are deposited by the adjacent cells (3-5). In tissue culture, epithelial cells have been found to produce (6-9) and occasionally also deposit BM compohents into BM-like structures (10-13). Dissociated epidermal cells, however, usually do not deposit a BM in vitro (14). Some epithelial tumor cells do and others do not produce BM components in vitro (9). Recombined chick mesenchyme and rat endoderm, however, shows formation of a BM of chick i.e. mesenchymal origin (15). In xenotransplants of human carcinoma cells BM are deposited which contain elements of stromal (host)/as well as tumor cell (human) origin $(16,17)$. These findings indicate that epithelial BM may be of epithelial or stromal or combined origin and are deposited probably as a result of a specific interaction between epithellal and stromal cells. What exactly regulates the deposition of a BM is unknown. Involvement of extracellular matrix components is likely in view of the experiments which show that on a plastic substratum cultured mammary or epidermal cells do not deposit BM-like material, whereas on a type 1 collagen substratum or in a type I collagen gel patches of BM-like material are deposited pericellularly $(13,14,18-20)$. In reviewing the literature a striking finding is that many cell types appear to produce BM components in vitro, but do not deposit a BM-like structure. Xenografting of such cells, however, often yields neoplastic carcinoma cell nests surrounded by a usually irregular and discontinuous but linear deposit of BM material.

In this study we have investigated the capacity of neoplastic epithelial cells to produce and cleposit a BM in vitro under a variety of circumstances. Special attention was paid to the question whether or not interaction with fibroblasts, myofibroblasts or endothelial cells might induce the deposition of a BM.

\subsection{Materials and methods}

\subsubsection{Cell lines}

The cell lines used are listed in Table 1. 
Table 1. Main characteristics of the used cells

\begin{tabular}{lll}
\hline cell type/type & source & reference \\
\hline $5583-\mathrm{E}$ & colon carcinoma & Verstinen et al. (21) \\
HT 29 & colon carcinoma & Fogh et a. (22) \\
KB & epitheloid carcinoma & Eagle (23) \\
WISH & transformed amnion & Hayflick (24) \\
fibroblasts & human skin & \\
myofibroblasts & human umbilical cord & chapter 5 \\
endothelial cells & human umbilical cord & \\
\hline
\end{tabular}

\subsubsection{Tissue culture}

Most cells were cultured in Dulbecco's modified Eagles minimum essentiat hedium supplemented with $10 \%$ fetal calf serum in a $37^{\circ} \mathrm{C}$ incubator with $5 \% \mathrm{CO}_{2}$

Endothelial cells were cultured in RPMI/M199 medium with $20 \%$ newborn calf serum, 20 $\mathrm{U} / \mathrm{ml}$ Heparin (25) and $88 \mu \mathrm{g} / \mathrm{ml}$ endothelial cell growth factor (26). In an attempt to induce extracellular matrix (ECM) production the cells were cultured with ascorbic acid (50) $\mu \mathrm{g} / \mathrm{ml}$ ), endothelial cell conditioned culture supernatant ( $10 \%$ of total volume), or epidermal growth factor (EGF, Gibco Laboratories, Chaygrin Falls, Ohio) (concentration 1, 5 and $10 \mathrm{ng} / \mathrm{ml}$ ). Furthermore, the cells were cultured on tissue culture plastics, $1 \%$ gelatin coated glass slides and in or on type I collagen lattices. Type I collagen lattices were prepared according to Bell et al. (27) and Nusgers et al. (28) by mixing cold stock solution (4 $\mathrm{mg} / \mathrm{ml}$ type I collagen isolated from human placenta solubilized in $0.1 \% \mathrm{HAc}$ ) with culture medium and $0.1 \mathrm{~N} \mathrm{NaOH}$ to neutralize the $\mathrm{pH}$. The final concentration of type I collagen was $0.7,1$ or $2 \mathrm{mg} / \mathrm{ml}$. Reaggregation took place as soon as the solution was neutralized and brought to $37^{\circ} \mathrm{C}$ (chapter 9.8 ). These lattices were populated with fibroblasts or myofibroblasts and/or endothelial cells in order to create a connective tissue like substrate in witro.

\subsubsection{Isolation of denuded amniotic membranes}

Human amnion was separated from chorion and the amniotic BM was isolatted by chemcal and mechamical treatment as described by Liotta et al. (29). In shont amnion wits washed one hour in distilled water and $2 \mathrm{mM}$ N-ethylmaleimide (NEM), extrocted one hour with $1 \mathrm{M} \mathrm{NaCl}, 20 \mathrm{mM}$ EDTA, $2 \mathrm{mM} \mathrm{NEM}$ and finally one hour with $4 \%$ de-oxycholate. After each step the membranes were mechanically treated with a rubber police man to remove amniotic epithelial cells and most of the interstitial stroma. The membranes were suspended in a metal ring and sterilised by washing in PBS supplemented with penicillin/streptomycin, before culturing cells on the surface. 


\subsubsection{Xenografting}

Tumor cells were subcutaneously transplanted into nude rats (Athymic nu/nu) and harvested when the tumor reached $0.5-1 \mathrm{~cm}$ in diameter. Tumor material was fixed in $4 \%$ buffered formaldehyde and embedded in paraffin or frozen in OCT-compound (Lab-Tek produets, Naperville, USA) with ssopentane quenched in liquid nitrogen. Tissue sections of 4 un were cut and used for staining.

\subsubsection{Dot- and immunoblotting}

Tissue culture supernantants were precipitated with $4.5 \mathrm{M} \mathrm{NaCl}$ or $50 \%$ ammonium-

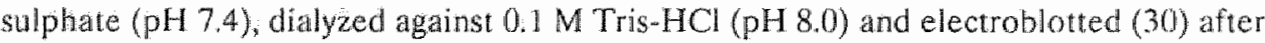
$5 \%$ polyacrylamide gelelectrophoresis (31, chapter 9.5). The supernatants were also spotted onto nitrocellulose sheets by applying $100 \mu \mathrm{culture}$ supernatant on the paper using a Bio-dot apparatus (Bio-rad, Utrecht, The Netherlands). After western and dot bloting immunostaining was performed as described under immunohistochemistry.

\subsubsection{Northern blotting}

Cultured cells were isolated by trypsin digestion. Nuclei were isolated (32). The nuclear pellet was removed, the supernatant extracted with phenol-chloroform and the RNA was precipitated in ethanol. Total RNA was separated by electrophoresis in agarose-formaldehycle gels and blotted overnight onto a genescreen filter. The blot was air dried, baked, and prehybridized with a solution containing $\mathrm{NaCl}$, Na-citrate, $\mathrm{Na}$-phosphate, polyvinyl pyrrollidone, bovine serum albumin, ficoll, denaturated salmon sperm DNA and formamide. Hybridization of RNA-cDNA was carried out in the same solution containing the labeled type IV collagen cDNA probe (33). The type IV collagen probe was labeled with the random primer labeling method $(34,35)$ with ${ }^{32} \mathrm{P}$-dCTP. After hybridization the filter was washed, dried and exposed to a Kodak X-Omat film. This method is extensively outlined in chapter 9.6 .

\subsubsection{In situ hybridization}

$4 \mu m$ frozen sections were mounted on RNase free coated slides, fixed with freshly prepared $4 \%$ paraformaldehyde and washed with PBS, baked, washed again and treated with Triton $X-100$. After washing in PBS the sections were incubated with proteinase $K$ in a buffer containing Tris and EDTA. The sections were fixed again with $4 \%$ buffered paraformaldehyde, washed with PBS and treated with acetic anhydride in triethanolamine and furthermore incubated with formamide in $2 x$ SSC. $^{35} \mathrm{~S}-\mathrm{dCTP}$ labeled type IV collagen probe (33) was prepared according to the random primed labeling method using a Boehringer labeling kit $(34,35)$. $15 \mu$ probe/hybridization mixture containing $300,000 \mathrm{cpm}$ was applied to each section. The sections were subsequently covered with $22 \times 22 \mathrm{~mm}$ sili- 
conized coverslips and sealed with rubber cement. Hybridization mixture contained yeast t-RNA, salmon sperm DNA, deionized formamide, Tris- $\mathrm{HCl}, \mathrm{NaCl}$, EDTA, Denhardt's mixture, Dextran sulphate, and DTT. After $12-16 \mathrm{~h}$ incubation at $50^{\circ} \mathrm{C}$, the coverslips were removed and the slides were washed with SSC. Following these steps the slides were delyydrated in graded series of ethanol, air dried and coated with Kodak NTB-2 nuclear track emulsion and exposed for varying periods of time. The exposed slides were developed in 1:1 Kodak D-19 developer, fixed and counterstained with hematoxylin, dehydrated and mounted. Parallel sections were hybridized with an ${ }^{35} \mathrm{~S}$ labeled empty plasmid as a negative control. This method is extensively described in chapter 9.7.

\subsubsection{Immunohistochemistry}

Western blots, dot blots, paraffin- and frozen sections were stained by an undirect immunoperoxidase method. Frozen sections $(4 \mu \mathrm{m})$ were air-dried and fixed in acetone. Paraffin sections were first deparaffinized. The sections were washed with PBS and incubated with the primary antibodies. After washing with PBS the sections were incubated with peroxidase labeled conjugate. After washing in PBS, peroxiclase activity was visualized by incubation with diaminobenzidine- $\mathrm{H}_{2} \mathrm{O}_{2}$ substrate (chapter 9.2 and 9.3). Before applying the primary antibody to western blots and dot blots the nitrocellulose paper was treated with PBS and $1 \%$ bovine serum albumin or $0.05 \%$ Tween 20 to prevent aspecific binding of the antibodies.

Antibodies used were human specific monoclonal antibodies to type IV collagen (1043 and 1042, the latter is also reactive with rabbit BM) (36); cross species reactive rabbit antihuman type IV collagen polyclonal antibodies (36); mouse monoclonal anti-human laminin antibody (4E10) provided by U. Wewer (37); polyclonal rabbit anti-mouse (EHS) laminin antibody, cross reactive with human laminin epitopes, prepared by immunizing rabbits intracutaneouslly with $100 \mu \mathrm{g}$ laminin (E/Y Laboratories) as described in chapter 9.4.

\subsubsection{Electron microscopy}

Tissue fragments of approximately $1.2 \mathrm{~mm}^{3}$ were fixed in $2.5 \%$ glutaraldehyde in $0.1 \mathrm{M} \mathrm{s0}$ dium phosphatebuffer $\mathrm{pH} 7.2$, postfixed 1 hr $\mathrm{in} 1 \%$ OsO4, dehydrated in a graded series of alcohols and embedded in Epon. Ultrathin sections where stained with uranyl acetate and Jead citrate.

\subsection{Results}

The production of BM components by cultured cells and their tendency to deposit these into a BM under various conditions were studied in 3 different cell types: tumor cells which do and others which do not produce BM components in witro and myofibroblasts which under certain conditions deposit a BM-like structure in vitro. 
Under standard conditions in tissue culture 5583-E and HT-29 cells, derived from human colonic carcinoma, did not produce type IV collagen. Immunocytochemistry of the culured cells and immunoblots of culture supernatants did not show any immunoreactivity for type IV collagen. By in situ bybridization type IV collagen mRNA could not be detected in these cells Addition of ascorbic acid, endothelial cell conditioned medium or EGF did not induce the cells to produce BM components. Culturing of these cells on amniotic BM, type I collagen or in type I collagen lattices with and without the addition of skin fibroblasts, umbilical cord myofibroblasts or umbilical cord endothelial cells did not alter this situation.

Under standard conditions WISH and KB cells produced detectable amounts of type IV collagen in the culture supernatant, as demonstrated by dot-blotting and western blotting as shown in Table 2 and Fig 1 . On western blots the pro $\alpha 1$ and pro az-chain of type IV collagen could be detected using a polyclonal anti-type IV collagen antibody. By immunohistochemistry using antibodies to basement membrane components peri- and sometimes intracellular immunoreactivity was noted when these cells were grown on gelatin coated glass slides or centrifuged on glass slides (Table 3, Fig 2).

Granular extracellular staining was observed with monoclonal antibodies to type IV collagen and with polyclonal antibodies to type IV collagen and laminin also intracytoplasmic staining was observed. By northern analysis of WISH and KB cells, traces of type IV collagen mRNA could be detected. By in situ hybridization weak cytoplasmic labeling was found using the type IV collagen CDNA probe.

Table 2. Production of type IV collagen in witro determined by northern, western, and dot-blotting

\begin{tabular}{llll} 
cell line/type & northern blot & western blot & dot blot \\
\hline $5583-\mathrm{E}$ & - & - & - \\
HT-29 & nd & - & + \\
WISH & $+1-$ & $+(185,170 \mathrm{kD})$ & + \\
$\mathrm{KB}$ & $+1-$ & $+(185,170 \mathrm{kD})$ & + \\
Myofibroblasts & ++ & nd & ++
\end{tabular}

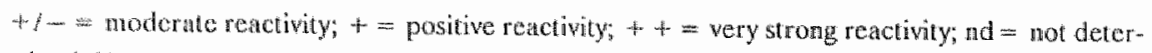
mined; $\mathrm{kD}=$ molecular weight in kiloDalton 


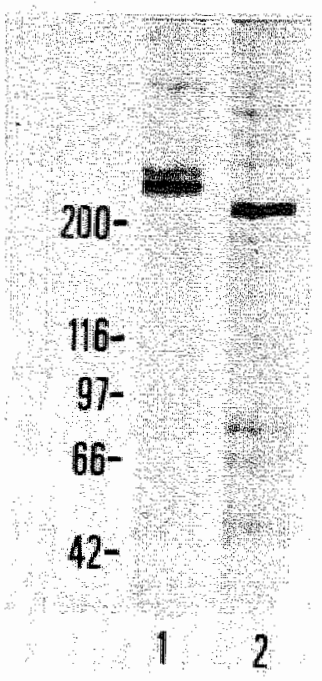

Figure 1. Inmunoblot after $5 \%$ SDS-polyacramide gelelectrophoresis of $4.5 \mathrm{M} \mathrm{NaCl} \mathrm{precipinate} \mathrm{of} \mathrm{WISH}$ culture supernatant.

Lane I: stained with polyclonal anti-laminin antiserunin;

Lane 2: stained with polyclonal anti-type IV collagen antisistum.

Table 3. Immunoperoxidase staining of frozen sections and cells grown on glass slides

\begin{tabular}{llllll}
\hline & $\begin{array}{l}\text { lattice } \\
\text { cell type }\end{array}$ & $\begin{array}{l}\text { in/on } \\
\text { + fibroblasts }\end{array}$ & $\begin{array}{c}\text { +endothelial } \\
\text { cells }\end{array}$ & + myofibroblasts & \\
\hline $5583-\mathrm{E}$ & - & - & - & - & - \\
WISH & - & - & - & - & + gran \\
KB & - & - & - & - & + gran \\
Myofibroblasts & $+4(p c)$ & nd & nd & nd & + pc/gran \\
Endothelial cells - & - & nd & - & + pc/gran
\end{tabular}

$\mathrm{pc}=$ pericellular; gran $=$ granular; nd $=$ not determined. 


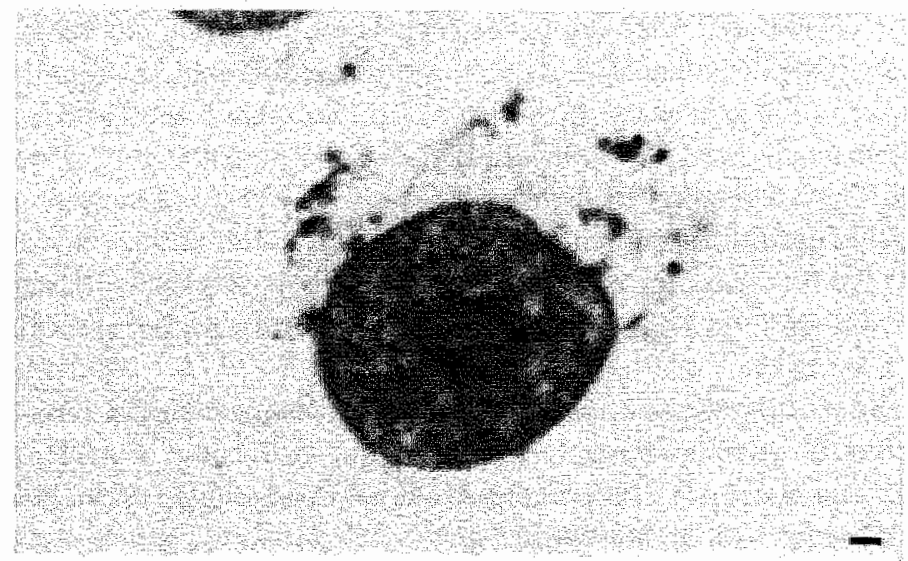

Figure 2. Cytospin of $\mathrm{KB}$ cells grown in witro and stained with monoclonal anti-type IV collagen antibodlies. Scale bar $=1$ unt.

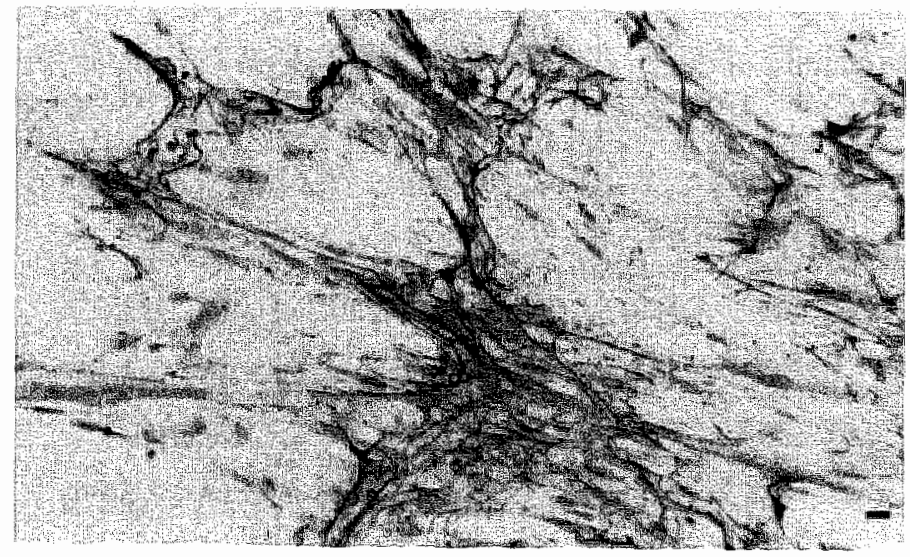

Figure 3. Umbilicall cond stromul cells (nnyonbroblasts) grown on gelatin coated glass slides stained with monoclonall anti-lype IV collagen antibodies. Scale bar $=10 \mu \mathrm{m}$.

Cocultivation of these cells in type I collagen lattices with myofibroblasts and endothelial cells did not alter this situation. The production of small amounts of type IV collagen remained but no formation of an extracellular BM-like structure could be demonstrated. KB and WISH xenografted into nude rats, showed discontimuous but linear BM fragments between the tumor cells and at the transition of tumor cells and bost stroma (Table 4). Under standard conditions in vitro the umbilical cord stromal myofibroblasts produced large quantities of type IV collagen. This was detectable by immunoblotting in the tissue culture supernatant as well as by immunocytochemistry. 
Table 4. Immunoperoxidase staining with human specific anti-type IV collagen monoclonal antibodies on frozen sections of rat xenografts

\section{between tumorcells transition rat stroma/tumorcells}

\begin{tabular}{lll}
$5583-\mathrm{E}$ & - & - \\
$\mathrm{HT}-29$ & - & - \\
WISH & + BM/gran & + BM/gran \\
$\mathrm{KB}$ & + BM/gran & + BM/gran \\
\hline
\end{tabular}

$\mathrm{BM}=$ basement membrane like structures; $\mathrm{gran}=$ granular

Strikingly, when the cells grew in multilayered sheets, in addition to granular intracytow plasmic staining linear extracellular inmunoreactivity for type IV collagen was observed (Fig 3). By northern analysis large quantities of type IV collagen mRNA could be demonstrated and this result was confined by in situ hybridization. By electron microscopy of myofibroblasts cultured in a type I collagen lattice focal BM structures, including a lamina lucida and Jamina densa, were observed.

\subsection{Discussion}

BM components are released into the culture medium by some cell lines cultured in witro $(6,7,9)$. However, the assembly of these components into a BM-like structure is rarely observed (8). When cells are grown on normal tissue culture plastics, the formation of a BMlike structure is never seen. However, some investigators observed deposition of BM-like structures when epithelial cells were cultured in or on collagen gels $(13,18,19)$. This fincting suggests that mesenchymal stroma may be one of the factors involved in the regulation of the functional activity of epithelial cells (20).

The present study addressed two questions. Firstly, whether mesenchymal cells could induce production of BM components in epithellial cells which do not produce these substances under standard conditions. Secondly, whether mesenchymal cells could induce assembly in vitro of the produced $\mathrm{BM}$ components into BM-like structures.

In order to answer these questions we first established that the colonic tumor cell lines 5583-E and HT-29 do not produce type IV collagen in vitro, neither by immunohistochemistry on cells grown on glass slides nor by electrophoresis of the culture medium followed by immunoblotting nor by in situ hybridization using a type IV collagen cDNA probe 
(33). In contrast, the other two cancer cell tines $\mathrm{KB}$ and WISH produced type IV collagen in vitro. Pro $\alpha 1$ and pro az chains of type $I V$ collagen were detected after electrophoresis and immunoblotting of culture media. Immunohistochemistry of cultured cells showed predominantly extracellular but also sometimes intracellular punctated immunoreactivity, suggesting that the BM components are produced and secreted but not deposited into BMlike structures. When xenografted into nude rats/mice all cell lines (5583-E, HT-29, KB, WISH) gave rise to tumors with clearly demonstrable BM structures, derived from murine stromal cells (17). In KB and WISH xenografts the BM are partly deposited by the tumor cells and partly by the stromal cells. When combined, these findings suggest that epithelial/stromal cell interactions might induce epithelial cells to deposit a BM-like structure.

BM assembly as such is not impossible in vitro. This is demonstrated by the myofibroblasts from the umbilical cord stroma which showed, when the cells grew in multilayers, BM-like structures similar to those seen in vivo.

Our experiments clearly show that cocultivation of 5583-E and HT-29 cells with umbilical cord myofibroblasts, skin fibroblasts or umbilical cord endothelium cannot induce these cells to produce BM components. Even cells, such as KB and WISH, which spontaneously produce $B M$ components, cannot be induced in vitro by mesenchymal cells to assemble these components into a BM-like structure.

Our results lead to the following conclusions:

1. Some human cancer cells (5583-E, HT-29) do not release, whereas others (WISH, KB) do release $B M$ components in witro. Only umbilical cord inyofibroblasts deposit a recognizable BM in vitro.

2. Human cancer cells xenografted into nude rats, give rise to carcinomas, in which BM are deposited around tumor cell nests.

3. Cocultivation with fibroblasts, myofibroblasts or endothelial cells neither induce 5583-E and HT-29 cells to produce BM components nor induce WISH and KB cells to deposit a structurally recognizable BM in vitro.

4. Although evidently epithelial/stromal interactions do play a role in the deposition of a BM structure, the factors which regulate this process remain unknown.

\subsection{Reterences}

1. Veacko R: The role of basal lamina in maintenance of orderiy tissue st ructure. In: New trends in batsement mambranc rescarch. Kilh $K$, Schöe K, Timpl R, eds. Raven Press, New York 1, 1982

2. Clenjons JPM. Havenith MG, Vallinga M, Bosman FT: Absence of type JV collagen in corneal cpithelat basement menbrane. Subritled.

3. Pierce GB, Bealsi TE, Sri Ram T, Midgley AR: Basement membranes. IV. Epithelal origin and immunologic cross reatction. Am J Pathol 45,929, 1964

4. Dodson JW, Hay ED: Secretion of collagenous stroma by isolated epitheliun grown in vitro. Exp Cell Res $65,215,1971$ 
S. Banerjee SD, Cotn RH, Bernfeld MR: Basal lamina of embryonic sativary epithetimm production by the epithelium and role in maintaining lobular morphology. $J$ Cell bol $73,445,1977$

6. Alitalo $\mathrm{K}$, Vaheri $\mathrm{A}_{\mathrm{K}} \mathrm{Krieg} \mathrm{Th}$, Timpl R: Biosynhesis of two subunits of thpe IV procollagen and of other basement membrane proteins by a human tumor cell line. Eur J Biochem 109, 24\%, 1980

7. Scarpa $S_{n}$ Modesti $A$, Triche TV Extracellular matrix symthesis by undiferentiated childhod tumor col lines. Am J Pathol 129,74, 1987

8. David $\mathrm{O}$, Nasgens B, Schueren wan der B, Cauwenberge D, Berghe van den H, Lapiere Ch: Collagen metabolism and busement membrane Cormation in cultures of mouse mammary epithedial cells. Exp Cull Res $170,402,1987$

9. Hornung J, Biohnert A, Phan-Than L, Krieg T, Fusenig NE: Basement menbrane formation by malignan! mouse keratinocyte cell lines in organotypic culture and transplants: correlation whth degres of nnorpholo. gie differentiation. J Cancer Res Clin Oncol 113, 325, 1987

10. Emerman IT, Worth AJ: Phenotypic stability of mouse mammary tumor cells cultured on collagen gells, Dev Biol 21, 49, 1985

11. Brownell AG, Bessem CC, Slavkin HC: Passible functions of mesenchyme cell-cerived libronectin during formation of basal lamina. Dev Biol 78, 3711, 1981

12. Garbi $\mathrm{C}$, Wollnan SH: Basal lamina formation on thyroid epithelia in separated follicles in suspension cul. ture. J Cell Biol 94, 489, 1982

13. Heathcote G, Bruns RR, Orkin RW; Biosynthesis of sulphated macromolecules by rabbit lens epinelium. I. Relationship to basement membrane formation. J Cell biol $99,861,1984$

14. Bohnert A, Hornung J, Mackenzie IC, Fusenig NE: Epithelial-mesenchymal interactions control basement membrane production and differentiation in cultured and transplanted mouse keratinocytes. Cell Tissus: Res 244, 413, 1986

15. Simon-Assmann $P$, Bouziges $F$, Arnold $C$, Haffen $K$, Kedinger $M$ : Epithelial-mesenchymal interactions in the production of basement menbrane components in the gut. Deweloprnent 102, 339, 1948

16. Damjanoy I, Damjanow $N$, Knowles $B B$, Engvall E: Origin of laminin in the extracethular matrix of thuman turnor жenografts in nude mice. Virch Arch [B] 49, 45, 1985

17. Cleutjens JPM, Hawenith MG, Vallinga M, Bosman FT: Origin of basement membrane type IV collagen in xenografted human epithelial tnmor cell-lines. Submitted. This thesis chapter 6.

18. Emerman T, Pitelka DR: Maintenance and induction of morphological differentiation in dissociatiod manmary epithelium on floating collagen membranes. In Vitro 13, 316, 1977

19. Hirone $\mathbb{T}$, Taniguchi S: Basal lamina formation by epidermal cells in cell culture. In: Current problems in dermalology. Bernstein TA, Seiji M, eds. Karger AG, Basel. 10, 159, 1980

20. Karst W, Merker HJ: The differentiation behaviour of MDCK cells grown on matrix components and in collagen gels. Cell Differentiation 22,211, 1988

21. Verstijnen CPHI, Arends JW, Moerkerk PTM, Geraedts JPM, Uitendaal MP, Bosmán FT: The conablishment and characterization of two new cell lines derived from a single human colonic adenocarcinoma. Virch Arch [B] $53,191,1987$

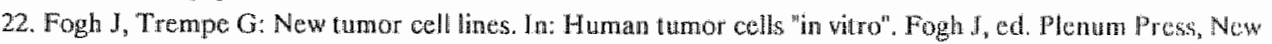
York. 115, 1975

23. Hayflick L: The establishment of a line (WISH) of human amnion cells in continuous cultivation. Exp (xull Res 23, 14, 1961

24. Eagle H: Propagation in a fluid medim of human epidermoid carcinoma strain KB. Proc Soc Exp Buxk (N.Y.) $89,362,1955$

25. Thornton SC, Mueller SM, Lexine EL: Human cndothelial cells: usc of heparin it cloning long term serial cultivation. Science $222,623,1983$ 
26. Maciag T, Cerundolo J, Isley S, Kelley PR, Forand R: An endothelial cell growth factor from bovine hypothalamus: Identification and pertial characterization. Proc Nat Acad Sci USA 76, 5674, 1979

27. $\mathrm{Belll} \mathrm{E}_{\text {, }}$ Ivarsson $\mathrm{B}_{\text {; }}$ Merrill $\mathrm{Ch}$ : Production of at tissue Whe structure by contraction of collagen lattices by human fibrobtasts of different proliferative potential in vitro. Cell Biol 76, 1274, 1979

28. Nusgens $\mathrm{B}_{3}$ Merrill Ch, Lapiere Ch, Bell E: Collagen biosynthesis by cells in a tissue equivalen matrix in witro. Collagen Rel Res 4, 351, 1984

29. Liotta $L A_{i}$ Lee CW, Morakis DI: New method for preparing large surfaces of intact human basement mem brane for lumor invasion studies. Cancer Letters 11, 141, 1980

30. Towbin $\mathrm{H}$, Statelin T, Gordon J: Electrophoretic transfer of proteins from polyacrylamide gels lo nitrocelluluse sheets: procedure and some applicalions. Proc Nall Acad Sei USA 76, 4350, 1979

31. Lacmmli UK: Cleawage of structural proteins during the assembly of the head of bacteriophage T4. Nature $227,680,1970$

32. Schrier PI, Berwards $R$, Vaessen RTMJ, Houweling $A$, van der Eb AJ: Expression of class I major histocompatibility antigens switched off by highly oncogenic adenovirus 12 in transformed rat cels. Nature 305,771 , 1983

33. Pihlajaniemi $T$, Tryggvason $K$, Myers JC, Kurkinen $M$, Lebo R, Chüng M, Prockop DJ: cDNA clones cod ing for the pro $\alpha$ IV chain of human procollagen reveal an unusual homology of amino acid sequences in two halves of the carboxyl-terminal domain. I Biol Chem 260, 7681, 1985

34. Foinberg $A P$, Vogelstein B: A technique for radiolabeling DNA restriction endonuclease fragments to high specinc activity. Anal Biochem 132, 6, 1983

35. Feinberg AP, Vogelstein B: Addendum: A technique for radiolabeling DNA restriction endonuclease fragments to high specific activity. Anal Biochem 137, 266, 1984

36. Hawernith MG, Cleutjens JPM, Beek C, v.d. Linden JE, De Goej AFPM, Bosman FT: Human specific antitype IV collagen monoclonal antibodies, characterization and application to immunohistochemistry. Histochemistry $87,123,1987$

37. Wewer $U$, Albrechtsen $R$, Mathorpe $M$, Varon $S_{n}$ Engrall $E$, $R$ uoslahti $E$. Human laminin isolated in a nearly intace, biologically active form from placenta by limited proteolysis. J Buol Chem 258, 12654, 1983 


\section{Chapter 8}

General discussion 


\section{1 introduction}

In this chapter the results will be discussed in a somewhat broader context. This will be done by postulating the following three questions:

a. Is it likely that basement membranes (BM) contain more components then those presently known and if so, how can they be identified?

b. Do all BM have a uniform morphology and structure?

c. How is the epithelial BM deposited?

\subsection{New BM components?}

Several BM components have been isolated and characterized. The best characterized BM components are laminin, type IV collagen, heparan sulphate proteoglycan and entactin. However, it has been postulated that more different BM components will eventually be identifiled in the near future $(1,2)$, due to new isolation techniques and increasing interest in extracellular matrix research.

In animal models, such as the mouse. EHS-tumor and rat parietal yolk sac carcinoma, cross-linking of newly synthesized collagen can be prevented by treatment of the animals with B-amino-propionitrile fumarate (BAPN) (3). This procedure facilitates the isolation of the BM components. In man, however, the BAPN approach can not be used. Consequently, isolation of human BM components is hampered by the strong cross-links which occur among and between the different BM components. Enzymatic cleavage is essential for isolation of human BM components $(1,4)$. This method, however, provides only fragmented information, comparable to the pottery fragments archeologists have to rely on in reconstructing images of the past. For example, pepsin cleavage of human BM, yields only the triple helical part of the molecule (4), whereas the globular $\mathrm{NCl}$-domain is completely degraded. In contrast, bacterial collagenase only yields the globular NC1-domain and destroys the triple helix of type IV collagen (5). During these procedures components which occur in very low concentrations can remain undetected (6).

An alternative approach is the use of the hybridoma technology to generate monoclonal antibodies after immunization with native BM fragments. With this method, antibodies can be generated which might recognize new BM components, but also variations in the molecular and supramolecular structure of well known components, as described in chapters 2 and 3 . However, the adwantage of this approach is also its major drawback. The epitopes of the generated monoclonal antibodies tend to be largely conformational, which implies that they can only be detected in their native structure and, for example, not after fixation of the tissue. This is a serious handicap for immuno-electron microscopical investigations or for retrospective studies on formaldehyde fixed and paraffin embedded archival human tissues. Furthermore, isolation procedures might destroy the native conformation of the epitopes, and interfere with their immunoreactivity. The practical and scientific value of such a monoclonal antibody would be somewhat limited, because the biochemical 
and physiological properties of the epitope can not be elucidated. An alternative approuch towards isolation of human BM components would be the xenotransplantation of human tumor cells, which produce considerable amounts of BM components, such as adenoid cystic carcinoma or endodermal simus tumour, into lathyritic athymic animals (3). In lathyritic animals the lysine derived cross-links, which are normally formed in the BM (mainly between type IV collagen molecules) do not occur. This approach allows the isolation of BM components by mild extraction methods, which might lead to the isolation of new and/or intact human BM components.

\subsection{Do all BM have a uniform structure and morphology?}

Most BM share the same ground structure and type IV collagen forms the structural backbone to which other components like laminin and heparan sulphate proteoglycan can attach (7). However, in normal BM differences in thickness can be observed (glomerular and alveolar BM), but also the relative concentration of the different BM components can vary $(8,9)$. A unique deviation of the usual BM structure and composition occurs in the epithelial BM of the human cornea. In contrast to the peripheral/conjunctival epithelial $B M$, the central corneal epithelial BM lacks immunoreactivity with antibodies to type IV collagen. Ultrastructurally a continuous lamina densa, which consists largely of type IV collagen molecules $(10,11)$, is absent. However, it can be argued that an epithelial/stromal interface without type IV collagen should not be called a BM. What goes on in the cornea? Are the epithelial cells directly anchored to the stromal collagen or does the stromal collagen locally replace the function of type IV collagen? One puzzling enigma, which is not discussed in the previous chapters, complicates this issue even further. The biochemical characterization of the target antigens of monoclonal antibodies (MA) 1052, 1053 and 1087, convincingly shows that they are reactive with the globular NC1 domain of type IV collagen. As one would expect, the central epithelial corneal BM does not react with MA 1087, but surprisingly MA 1052 and 1053 do react with this BM. A speculative explanation for these findings could be that the central corneal BM contains an altered type IV collagen which is not electrondense as in a lamina densa and does not react with most antibodies against type IV collagen.

Although a continuous BM surrounds some mesenchymal cells, such as fat, Schwann and muscle cells, other mesenchymal cells like myofibroblasts display discontinuous pericellular deposits of BM-like material. The BM patches are often irregularly shaped which suggests that some mechanisms regulating the assembly of BM components into a normal continuous $B M$ are lacking. These findings, together with the heterogeneous BM immunoreactivity observed with the MA 1052 and 1053 as well as other findings which iflustrate the heterogeneous nature of $\mathbb{B M}(12,13)$ lead to the conclusion that the structure and composition of a BM depends upon the tissue in which the BM is situated. The glomerular BM plays a specific role in ultrafiltration, and in contrast the epidermal BM has 
an important barrier function, and undoubtedly both are mediated by specific BM components: Furthermore, it is not unlikely that also the supramolecular structure of the common BM components is variable.

\subsection{How is the epithelial BM deposited?}

The generally accepted concept is that the epithelial BM is produced by the epithelial cells, adherent to this BM (8). However, taking into consideration that the BM is a layered structure with particular components occurring in different layers, as for example type IV collagen in the lamina densa $(10,11)$ and types IV and VII collagen in anchoring plaques in the mesenchyme (14), the mechanisms which regulate the production and assembly of BM components into a structurally recognizable BM must be rather complex. If epithelial cells produce all these components, newly synthesized molecules have to be transported through the entire BM before they can be deposited into e.g. the anchoring plaques. This is not impossible but it is hard to conceive of the mesenchyme as an inert domain as far as the BM is concerned.

In chapter 6 we could demonstrate that the epithelial BM of human tumor cells, xenografted into athymic animals, but also in the normal rat epidermis, is (partly) derived from mesenchymal cells. The mesenchymal cell, which is most likely responsible for the production and deposition of mesenchymal BM components, is the myofibroblast. In chapter 5 , we demonstrated that myofibroblasts can produce type IV collagen and laminin both in vivo and in vitro. Fibroblasts did not appear to do this, at least according to the techniques used, which appears to contradict the results of other investigators $(15,16)$, who showed that normal skin fibroblasts and embryonal fibroblasts may contain type IV collagen mRNA and produce type IV collagen. The nature of the myofibroblast is still incompletely resolved. Whether or not the umbilical cord myofibroblasts are comparable with the myofibroblasts which occur in healing wounds or desmoplastic reactions remains to be established. In normal resting tissue this cell type might contribute to the production and maintenance of the epithelial BM, but it cannot be excluded that these cells are rare in normal tissues, and that in this situation the epithelial BM is entirely an epithelial product. In desmoplasia and tissue repair they might be induced by the growth factors which sustain the neoplastic or reparative proliferation, transforming from fibroblasts into myofibroblasts, which then also contribute to the deposition of BM.

If the epithelial BM is the result of assembly of BM components produced by both epithelial cells and myofibroblasts the question arises which mechanisms in the interaction between epithelium and mesenchyme regulate BM deposition. In vitro studies have almost invariably shown that BM are not deposited adjacent to cells in tissue culture, which do produce BM components, in or on type I collagen cultured with or without mesenchymal cells and with or without additives in the culture medium (chapter 7). Our experiments have therefore failed to identify a trigger, needed for the assembly of components produced in witro into a BM. Strikingly, xenotransplantation of collagen lattices with epithelial 
cells results within 2-3 days in linear BM formation at the interface between the epithelial cells and the type I collagen lattice (17). These findings illustrate that in vitro the cellular, extracellular matrix or molecular components which are necessary for the assembly of BM are missing, because in vivo the formation of a $\mathrm{BM}$ is rapidiy induced. Knowledge of these regulatory mechanisms would shed new light on aspects of normal tissue development during embryology and tissue homeostasiis. Such knowledge might also tell us why do tumor cells differ in their tendency to deposit a BM at the stromal/epithelial interface, which appears to be a general reflection of the biological behaviour of the tumour cells as has been shown in colonic carcinoma (18).

\subsection{Future perspective}

The three questions posed in this general discussion have largely remained unanswered. We do not know whether or not more BM components exist, if so how many, what the molecules would look like and what their function might be. The interface between the central corneal epithelium and the underlying stroma and the nature of the myofibroblast remain intriguing puzzles. The origin of the epithelial BM and the regulation of its deposition can still be debated. These puzzles should be solved. Not only because questions always cry for an answer but because these answers would complete our basic insight in the composition, structure and function of the BM. This extracellular structure plays a central role in a variety of embryological, physiological and pathological phenomena, which will only be completely understood when the BM has unvelled most of its secrets.

\subsection{References}

1. Timpl R, Dziadek M: Structure, development, and molecular pathology of basement membranes Int Rev Exp Pathol 29, 1, 1986

2. Abrahamson DR: Postembeclding colloidal gold immunolocalization of laminin to the lamina rara interna, lamina densa, and lamina rara externa of renal glomerular basement membsanes. J Histochem Cyochom $34,847,1986$

3. Barsky $S H$, Laytield $L$, Varki $N$, Bhutas $S$ : Two thman tumors with high basement membranteproducing potcrial. Cancer 61, 1798, 1988

4. Havenith MG, Cleutjens JPM, Beek C, van der Linden E, De Goeil AFPM, Bosnitun FT: Human specillic anti type IV collagen monoclonal amtibodies, characterization and immunohistochemical application. Histochemistry $87,123,1987$

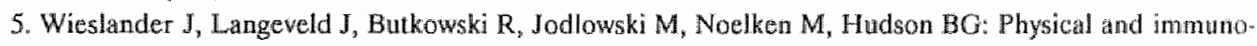
chemical studies of the globular domain of type IV collagen. J Biol Chem 260, 8564, 1985

6. Fitch JM, Linsenmayer TF: Monoclonal antibody analysis of ocular basement membranes during develop ment. Dev Biol 95, 137, 1983

7. Bosman, F, Havenith M, Cleutjems J: Basement membranes in cancer. Ultrastrtict Pathol 8, 291, 1985

8. Martinez-Hernandez A, Amenta P: The basement membrane in pathology. Lab Invest $48,656,1983$ 
9. Let F, Damfancy 1: Protease treatment combined with immunohistochenistry reveals heterogeneity of nor. mal and necplastio basement membrancs. J Histochem Cytochem 36, 213, 1988

10. Courtoy PJ, Timpl R. Farquhar MG: Comparatiwe distribution of Jaminim, lype IV collagen, and hbronec-

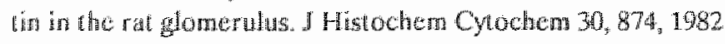

11. Farquhar MG. The glomerular basement membrane. A select me macromolecular filter In: Coll Biology of extricellular matrix, Hay ED, ed. Nev York, Plenum Press 335, 1981

12. Hessle $H_{0}$, Sakai L, Hollister $\mathrm{D}, \mathrm{B}$ ugeson $\mathrm{R}$, Engvall $\mathrm{E}$ : Basement membrane diversity detected by monoclonal antibodies. Differentiation $26,49,1984$

13. Hinsch K-D, Hansem D, Zimmemann $A$, Bruchhaten v. F: Production and immunohistochemical characterization of monoclonal antbodies directed against renal basement membrames of rats. Histol His. topath $3,325,1988$

14. Keene DR, Sakai LY, Lungtrum GP, Morris NP, Burgeson RE: Type VM collagen forms an extended metwork of anchoring fibrils. J Cell biol 104, 611, 1987

15. Pitulajuniemi $T$, Tryggwason K, Myers JC, Kurkinen M, Lebo R, Chüng M, Prockop DJ: cDNA clones coding for the pro $\alpha$. IV chain of humat procollagen reweal an unusual homology of amino acid sequences in two halwes of the catboxyl-terminal domain. J Biol Chem 260, 7681, 1985

16. Alitalo $\mathrm{K}$. Production of both interstitial and basement membrane procollagens by fibroblastic WI-38 cells from human embryonic ling. Biochem Bioplyys Res Commun 93, 873, 1980

17. Honung J, Bohnert A, Phars-Than L, Krieg T, Fusenig NE: Basement membrane formation by malignant mousc keratinocyte cell lines in organotypic culture and transplants: Correlation with degrce of morpholow gic differentiation. I Cancer Res Clin Oncol 113,325, 1987

18. Hawenith MG, Arends JW, Simon R, Volovics A, Whiggers T, Bosman FT: Type IV collagen immumoruantvity in colorectal cancer. Prognostic value of basement membrane aleposition. Cancer $62,2207,1988$ 


\section{Chapter 9}

Addendum 


\subsection{Immunization and monocional antibody production}

\subsubsection{Inmunization with amnotic BM}

Stripped amniotic membranes $\left(1.5 \mathrm{~cm}^{2}\right)$ were subcutaneously implanted three times with monthly intervals into the neck of Balb/c mice (TNO, Zeist). After thee months the mice were boosted intraperitoneally with minced amniotic membranes, supplemented with 50 $\mu g$ of a mixture from type IV and V collagen (1) and an $8 \mathrm{M}$ Urea extract of amniotic membranes (2). Three days after final booster injection, the spleen was removed for fusion.

\subsubsection{Immunization with glomerular BM}

Balb/c mice were immunized with $200 \mu \mathrm{g}$ freeze dried glomerular BM in Freund's complete adjuvant. The mice were boosted four times with $200 \mathrm{\mu g}$ freeze dried glomerular BM in Freund's incomplete adjuvant. Three days after the final booster injection the spleen was removed for fusion.

\subsubsection{Monoclonal antibody production}

A cell suspension of spleen cells was made in RPMI-medium by mincing the spleen through a sieve. Red blood cells were lysed by incubation with $0.155 \mathrm{M} \mathrm{NH4Cl,} \mathrm{(3.01)} \mathrm{M}$ KHCO, 0.1 mM EDTA, pH 7.4 for $2 \mathrm{~min}$. After three washings with RPMI, the cells were mixed (2:1) with $5 \mathrm{p} 2 / 0$ myeloma cells and centrifuged 5 min $1000 \mathrm{rpm}$. The cell pellet was gently dissolved in $40 \%$ Polyethylene glycol (PEG 4000, Merck, Darmstadt, FRG) and incubated for 2 min $37^{\circ} \mathrm{C}$. The fused cells were gently dissolved in RPMI and centrifuged 5 min $800 \mathrm{rpm}$. The cell pellet was dissolved in $25 \mathrm{ml}$ Hypoxantine-Aminopterine-Thymicline (Flow, Amstelstad, Zwanenburg, The Netherlands) supplemented Dulbecco's modified minimum essential Eagle's medium (Flow, Amstelstad, Zwanenburg, The Netherlands) and $20 \%$ fetal calf serum (Boehringer, Mannheim, FRG), and diluted in five 96-wells plates. After 3 and 7 days the medium was changed. Ten days after fusion the supernatants were tested on 4 wm frozen tissue sections as described under immunohistochemistry (chapter 9.2). Positive clones were recloned by limiting dilution until monoclonal, and tested for the presence of one isotype by ELISA using a mouse isotyper kit (Bio-rad, Utrecht, The Netherlands).

\subsection{Immunohistochemistry}

Frozen sections ( $4 \mu \mathrm{m})$ from human tissues were air-dried $15 \mathrm{~min}$ and fixed in acelone $(-20)$ $\left.{ }^{\circ} \mathrm{C}, 20 \mathrm{~min}\right)$. Purafin sections (4 jum) of $4 \%$ phosphate buffered paraformaldehyde fixed tissues were deparaffinized with xylol, hydrated and washed with PBS. Successively, frozen and parafin sections were incubated $(20 \mathrm{~min})$ with methanol and $0.3 \% \mathrm{H}_{2} \mathrm{O}_{2}$ to inactivate andogenous peroxidase reactivity, and washed 3 times 5 min with PBS. The sections were 
incubated with the primary antibody ( 1 br, room temperature (RT)). After washing with PBS (3 times $5 \mathrm{~min}$ ) the sections were incubated ( $1 \mathrm{hr}, \mathrm{RT}$ ) with a conjugated second layer, either peroxidase conjugated rabbit anti mouse IgG (Dakopatts, Glostrup, Denmark) or fluoresceine isothiocyanate conjugated rabbit anti mouse IgG (Dakopatts, Glostrup, Denmark), for monoclonal antibodies or peroxidase conjugated goat anti rabbit $\operatorname{lgG}$ (Nordic, Tilburg, The Netherlands) for polyclonal rabbit antisera. All antibody dilutions were prepared with PBS containing $1 \%$ ( $\mathrm{w} / \mathrm{v}$ ) bovine serum albumin (BSA, RIA grade, Sigma, St. Louis, USA). After washing in PBS ( 3 times 5 min), peroxidase activity was visualized by incubation with 3,3' diaminobenzidine (DAB, Serva, Heidelberg, FRG) $(0,5 \mathrm{mg} / \mathrm{ml}$ in 50 $\mathrm{mM}$ Tris $\mathrm{pH} 7,6$ and $0,002 \% \mathrm{H}_{2} \mathrm{O}_{2}$ ) for $7 \mathrm{~min}$ in the dark. Finally, the sections were washed in PBS and lightly counterstained with hematoxylin.

\subsection{Tissue pretreatment}

In order to expose the antigenic sites not accessible due to fixation and paraffin incubation, paraffin tissue sections were pretreated with pronase (Boehringer, Mannheim, FRG) 400 $\mu \mathrm{g} / \mathrm{ml}$ in $50 \mathrm{mM}$ TRIS-HCl buffer, $\mathrm{pH} 8.0$, for 30 minutes at $37^{\circ} \mathrm{C}$ (1) when monoclonal antibodies were applied, or with pepsin (Boehringer, Mannheim, FRG) $1 \mathrm{mg} / \mathrm{ml}$ in $0.01 \mathrm{~N}$ $\mathrm{HCl}, 30$ minutes at $\mathrm{RT}$ for the polyclonal antisera after deparaffinization and prior to inactivation of endogenous peroxidase reactivity.

\subsection{Antibodies}

The source and specifications of the antibodies used in this thesis are listed in table 1.

\subsection{Electrophoresis and Western blotting}

Freeze dried proteins were dissolved in sample buffer $(0.01 \mathrm{M}$ Tris, $0.001 \mathrm{M}$ EDTA, 1 \% SDS, $\mathrm{pH} 8.0$ ). Reduction of the proteins was performed by adding $5 \%$ mercaptocthanol and heating the sample during $5 \mathrm{~min}$ at $100^{\circ} \mathrm{C}$. The proteins were run on a $10 \%$ acryla mide $2.7 \%$ crosslinking separation gel and $5 \%$ acrylamide $2.7 \%$ cross-linking stacking gel or on a $5 \%$ acrylamide/ $2.7 \%$ crosslinking separation gel and $3 \%$ acrylamide $2.7 \%$ cross-linking stacking gel. The proteins were run $45 \mathrm{~min}$ (12) in a mini-Protean II electrophoresis cell (Bio-rad, Utrecht, The Netherlands). After electrophoresis the gels were incubated 3 times $5 \mathrm{~min}$ with blotting buffer (25 mM Tris, $192 \mathrm{mM}$ Glycin, $20 \%$ methanol (v/v), pH 8.3) to get rid of most of the SDS, and subsequently blotted (13) to nitrocelluiose paper (Schleicher \& Schüll, Dassel, FRG) using a mini-transblot electrophoretic transfer cell (Bio-rad, Utrecht, The Netherlands). Reference lanes with molecu- 


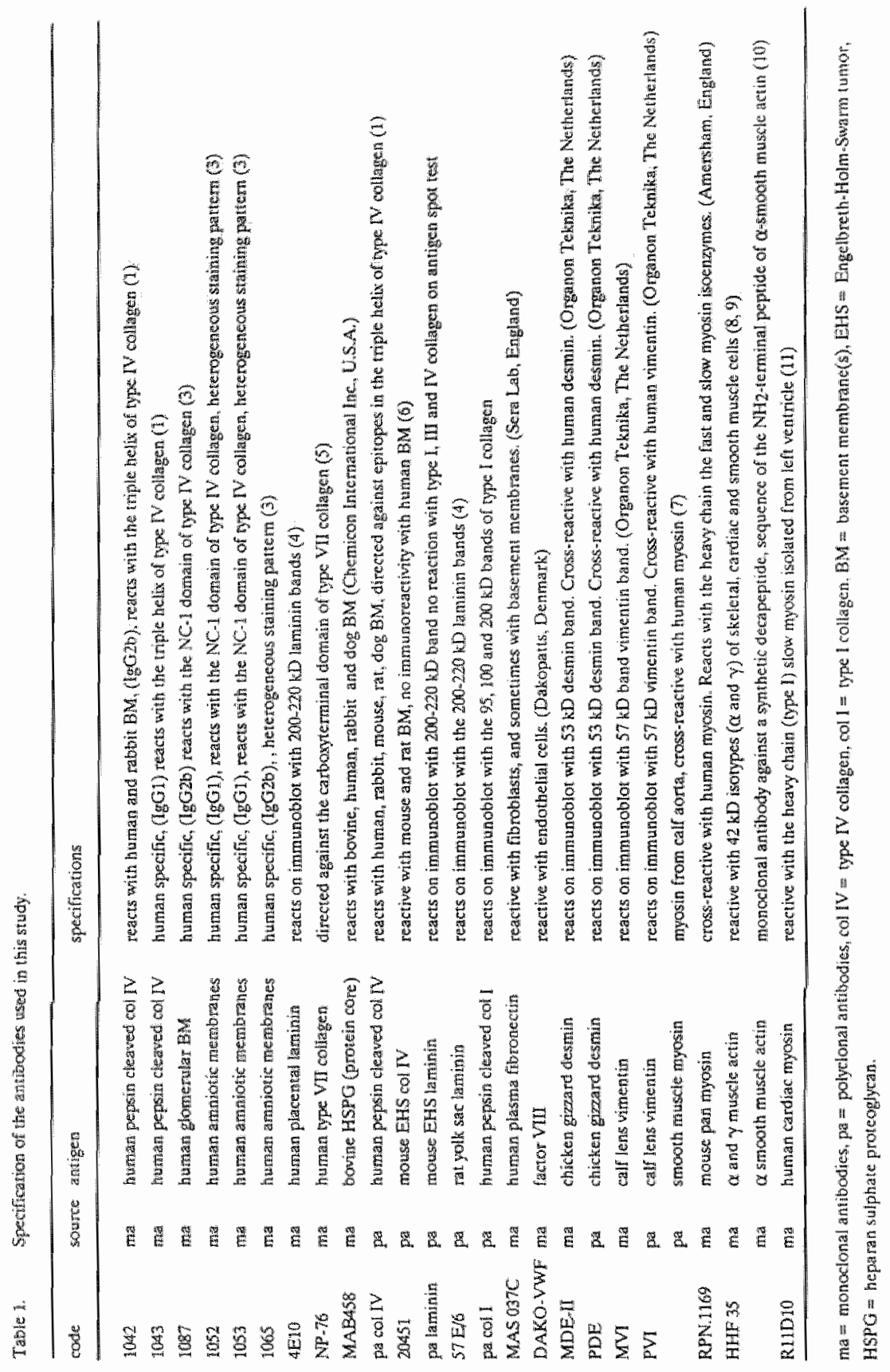


lar weight standards (Bio-Rad, Utrecht, The Netherlands) were washed with PBS and 0.3 $\%$ Tween-20 and stained with Aurodye $0.2 \mathrm{ml} / \mathrm{cm}^{2}$ (Janssen, Life Sciences, Olen, Belgium).

The nitrocellulose paper for immunostaining was treated either with PBS and $1 \%$ BSA or PBS and $0.3 \%$ Tween-20, and incubated with antibodies as described under immunohistochemistry (chapter 9.2).

\subsection{Northern blotting}

Cultured cells were isolated by trypsin digestion ( 3 min at $37^{\circ} \mathrm{C}$ with $0.25 \%$ trypsin (Difco Laboratories, Detroit, USA), in $0.1 \mathrm{M} \mathrm{NaCl}, 0.01 \mathrm{M}$ Tri-sodium citrate, $0.0015 \%$ phenol red, $\mathrm{pH} 7.8$ ), washing with PBS and centrifugation for $10 \mathrm{~min}$ at $500 \mathrm{~g}$. Cyloplasmic RNA was isolated by resuspending the cell pellet $1: 2(\mathrm{v} / \mathrm{v})$ in $10 \mathrm{mM}$ Tris- $\mathrm{HCl}(\mathrm{pH} 7.8), 1 \mathrm{mM}$ EDTA, $150 \mathrm{mM} \mathrm{NaCl}, 0.65 \% \mathrm{NP} 40$ and incubation for $5 \mathrm{~min}$ at $0^{\circ} \mathrm{C}(14)$. This solution was centrifuged for $5 \mathrm{~min}$ at $5000 \mathrm{~g}$. The supernatant was extracted four times with an equal volume of phenol/chloroform/isoamylalcohol $25: 24: 1(\mathrm{v} / \mathrm{v} / \mathrm{v})$ and $0.2 \%(\mathrm{v} / \mathrm{v})$ 8-hydroxyquinoline (in $10 \mathrm{mM} \mathrm{NaAc}, 1 \mathrm{mM}$ EDTA, $100 \mathrm{mM} \mathrm{NaCl} \mathrm{pH} \mathrm{5)} \mathrm{and} \mathrm{centrifuged} 5 \mathrm{~min} 3000 \mathrm{~g}$. The aqueous phase was extracted three times with Chloroform/isoamylalcohol $24: 1(\mathrm{v} / \mathrm{N})$. Finally, the RNA was precipitated overnight $4^{\circ} \mathrm{C}$ in $1: 2(\mathrm{v} / \mathrm{v})$ alcohol $96 \%$. The RNA was dissolved in $10 \mathrm{mM}$ Tris-HCl, $1 \mathrm{M}$ EDTA, $100 \mathrm{mM} \mathrm{NaCl}, 0.5 \%$ SDS pH 7.8. 10-20 $\mu \mathrm{g}$ total RNA was separated by electrophoresis in $1 \%$ agarose-formaldeliyde gels ( $1 \%$ agarose in $20 \mathrm{mM}$ 3-Mospholonipropanesulfonic acid, $5 \mathrm{mM} \mathrm{NaAc}, 1 \mathrm{mM}$ EDTA, $6 \%$ formaldehyde) for $22 \mathrm{hr}$ at $1.5 \mathrm{Vcm}^{-1}$ and blotted overnight onto a Genescreen plus filter (NEN Research Products, Boston, USA) in a buffer consisting of $254 \mathrm{ml} 20 \mathrm{xSC}(3 \mathrm{M} \mathrm{NACl}, 0.3 \mathrm{M}$ $\mathrm{Na}$-citrate $\mathrm{pH} 7.0$ ) and $46 \mathrm{ml} 37 \%$ formaldehyde. The blot was air dried and baked for $2 \mathrm{hr}$ at $80^{\circ} \mathrm{C}$. The filter was prehybridized during $16 \mathrm{hr}$ at $42^{\circ} \mathrm{C}$ in a solution containing $0.75 \mathrm{M}$ $\mathrm{NaCl}, 75 \mathrm{mM} \mathrm{Na}$-citrate, $50 \mathrm{mM} \mathrm{Na}$-phosphate, $0.02 \%$ (w/v) polyvinyl pyrrollidone, $0.02 \%$ $(w / v)$ bovine serum albumin, $0.02 \%(w / v)$ ficoll, $250 \mu \mathrm{g} / \mathrm{m}$ ] denaturated salmon sperm DNA (Sigma, Detroit, USA) and 50\% formamide. Hybridization of RNA-CDNA wals carried out for 24 b at $42^{\circ} \mathrm{C}$ in the same solution containing the labeled type IV collagen.cDNA probo (15). The type IV collagen probe was labeled with the random primer labeling methud (16. 17) with ${ }^{32} \mathrm{P}$-dCTP (3000 Ci/mM, Amersham, Utrecht, The Netherlands) to a specific activity of at least $510^{8} \mathrm{cpm} / \mu \mathrm{g}$. After hybridization the filter was washed $15 \mathrm{~min}$ in $2 \times \mathrm{SSC}$. $1 \%$ SDS $60^{\circ} \mathrm{C}$, two times 15 min in $1 \times$ SSC, $1 \%$ SDS $60^{\circ} \mathrm{C}$ and 15 min in $0.3 \times$ SSC, $10 \%$ SDS $65^{\circ} \mathrm{C}$. The filter was dried and autoradiographed using Kodak X-Omat films, for $24.48 \mathrm{hr}$. 


\subsection{In situ hybridization}

All solutions used in this procedure were treated with $0.1 \%$ diethylpyrocarbonate (DEPC) to inactivate RNase activity. Glass slides were coated with $0.15 \%(\mathrm{w} / \mathrm{v})$ chrome alum and $0.43 \%$ (w/v) gelatin. $4 \mu \mathrm{m}$ frozen sections were mounted on RNAse free coated slides, fixed 5 min with freshly prepared $4 \%$ paraformaldehyde and washed three times 5 min with PBS. Subsequently the slides were baked at $45^{\circ} \mathrm{C}$ for $2 \mathrm{~h}$. The slicles were washed 3 min in PBS (0.1 M, pH 7.2) at RT, treated $15 \mathrm{~min}$ with $0.3 \%$ Triton $X-100$ in PBS and washed two times 3 min with PBS. Furthermore, the sections were incubated for 20 min at $37^{\circ} \mathrm{C}$ with 1 $\mu \mathrm{g} / \mathrm{ml}$ proteinase K (Sigma, Detroit, USA) in $0.1 \mathrm{M}$ Tris ( $\mathrm{pH} 8.0$ ), $50 \mathrm{mM}$ EDTA, fixed again ( 5 min RT) with $4 \%$ buffered paraformaldehyde, washed two times 3 min with PBS and treated $(10 \mathrm{~min}, \mathrm{RT})$ with $0.25 \%$ acetic anhydride in $0.1 \mathrm{M}$ triethanolamine $\mathrm{pH} 8.0$ and furthermore incubated (at least $10 \mathrm{~min}, 37^{\circ} \mathrm{C}$ ) with $50 \%^{\circ}$ formamide in $2 \times \mathrm{SSC}$ ( $2 \times \mathrm{SSC}=$ $0.3 \mathrm{M} \mathrm{NaCl}, 0.03 \mathrm{M}$ trisodium citrate $\mathrm{pH} 7.0) .{ }^{35} \mathrm{~S}$-dCTP labeled type IV collagen probe (15) was prepared according to the random primed labeling method using a Boehringer labeling kit $(16,17) .15 \mathrm{ml}$ probe/hybridization mixture containing $300.000 \mathrm{cpm}$ was applied to each section. The sections were subsequently covered with $22 \times 22 \mathrm{~mm}$ siliconized coverslips and sealed with rubber cement. Hybridization mixture contained yeast t-RNA $(500 \mu \mathrm{g} / \mathrm{ml})$, salmon sperm DNA $(500 \mu \mathrm{g} / \mathrm{ml}), 50 \%$ deionized formamide, $10 \mathrm{mMTris}-\mathrm{HCl}$ pFl. 7.4, $0.3 \mathrm{M} \mathrm{NaCl}, 1 \mathrm{mM}$ EDTA, $2 x$ Denhardt's mixture ( $0.04 \%$ bovine serum albumin, $0.04 \%$ Ficoll $400,0.02 \%$ polyvinylpyrrolidon), $10 \%$ Dextran sulphate (Pharmacia, Uppsala, Sweden), $30 \mathrm{mM}$ DTT. After $12-16 \mathrm{~h}$ incubation at $50^{\circ} \mathrm{C}$, the coverslips were removed and the slides were washed four times 30 min RT with $4 \times$ SSC, three times 10 min at $37^{\circ} \mathrm{C}$ with $2 \times$ SSC and rinsed three times 10 min with $0.1 \times$ SSC. Following these steps the slides were dehydrated in graded series of ethanol, air dried and coated with Kodak NTB-2 nuclear track emulsion and exposed for varying periods of time. The exposed slides were developed in 1:1 Kodak D-19 developer $\left(4 \mathrm{~min}, 13-15^{\circ} \mathrm{C}\right.$ ), fixed, and counterstained with hematoxylin, dehydrated and mounted. Parallel sections were hybridized with an ${ }^{35} \mathrm{~S}$ labeled empty plasmid as a negative control.

\subsection{Type I collagen lattices}

\subsection{Isolation of human type I collagen}

Human type I collagen was prepared from human placenta by limited pepsin digestion and salt precipitation as described by Havenith et al. $(1,18)$. Briefly, a placenta was washed 3 times 3 hr with water, 4 times $6 \mathrm{hr}$ with $1 \mathrm{M} \mathrm{NaCl}, 50 \mathrm{mM}$ Tris-HCl pH 7.5 and 4 times $6 \mathrm{hr}$ with $0.5 \mathrm{MHAc}$. The placenta was minced with a meat grinder and digested $24 \mathrm{hr}$ with pep$\sin$ (Boehringer, Mannheim, FRG) enzyme/substrate ratio 1:400 (wet weight) dissolved in 1.5 M HAc pH 2.8. "The undigested material was separated by centrifugation 30 min 7000 
g. The digest was precipitated with $0.7 \mathrm{M} \mathrm{NaCl}$ (by adding solid $\mathrm{NaCl}$ ). The precipitate was dissolved again in 1.5 M HAc and precipitated once more with $0.7 \mathrm{M} \mathrm{NaCl}$. This precipitate was dialyzed against $0.5 \%$ HAc and freeze dried.

\subsubsection{Isolation of rat type I collagen}

Rat type I collagen was prepared by dissecting the four tendon buncles from the rat tail (19). The bundles were washed 30 min with $70 \%$ ethanol and incubated with PBS. Subsequently $1 \mathrm{~g}$ of stripped and washed tendons was incubated with $100 \mathrm{ml} 0.1 \% \mathrm{HAc}$ for 7 days at $4{ }^{\circ} \mathrm{C}$. The collagen mixture was clarified by centrifugation at $10000 \mathrm{~g}$ and freeze dried.

\subsubsection{Preparation of type I collagen latices}

Type I collagen lattices $(20,21)$ were prepared by mixing a cold stock solution of type I collagen $(4 \mathrm{mg} / \mathrm{ml}$ in $0.1 \% \mathrm{HAc}$ ) with cullture medium and $0.1 \mathrm{~N} \mathrm{NaOH}$ to neutralize the $\mathrm{pl}$. The end concentration of type I collagen was $0.7,1$ or $2 \mathrm{mg} / \mathrm{ml}$. Reaggregation took place as soon as the solution was neutralized and brought to $37^{\circ} \mathrm{C}$.

\subsection{References}

1. Havenith MG, Clentjens JPM, Beek C, wan der Linden E, De Goeij AFPM, Bosman FT: Human specilio anti type IV collagen monoclonal antibodies, characterization and immunohistochemical application. Histochemistry 87, 123, 1987

2. Ohno M, Martinez-Hernandez A, Ohno N, Kefalides NA: Isolation of laminin from human placental bascment membranés, amnion, chorion and chorionic microvessels. Biochem Biophys Res Comm 112, 1091, 1983

3. Cleutjens JPM, Beek $C$, wan Breda Vriesman PJC, Bosman FT: Biochemical and immunohishochemicut characterization of monoclonal antibodies against the NC1 globular domain of type IV collagen. Submitted. This thesis chapter 3 .

4. Wewer U, Albrechtsen R, Mathorpe M, Varon $S$, Engwall E, Ruoslabi E: Human laminin isolated in a nestIy inlach, biologically active form from placent a by limiled proteolysis. J Biol Chem 25\%, 12654; 1983

5. Sakai LY, Keene DR, Morris NP, Burgeson RE Type VII collagen is a major structural component of anchoring tibrils. J Cell Biol 103, 1577, 1986

6. Demarchez M, Hartmann DJ, Prunieras M: An imnunohistochemical study of the rewascularization process in human skin transplanted onto nude mouse. Transplantation 43, 896, 1987

7. Benzonana $G$, Martinello $G$, Gabbiani $G$ : Distribution of smooth muscie myosins in tissue sections is secn by immunofluorescence. Experientía 42, 650, 1986

8. Tsuknda T, Tippens D, Gordon D, Ross R, Gown AM: HHF35, a muscle-actin-specilic monoclonal ant ibody. 1. Immunocytochemical and biochenical characterization. Am J Pathol 126, 51, 1987

9. Tsukuda T, McNut MA, Ross R, Gown AM: HHF35, a muscle actin-specific monoclonal antibody. II. Ruactivity in normal, reactive, and neoplastic truman tissues. Am J Pathol 127, 389, 1987

10. Skalli $Q$, Ropraz P, Trzeciak A, Benzonana $G$, Gillessen, Gabbiani $G$ : A monoclonal antibody againsa ax-smooth muscle actin: A new probe for smooth muscle differentiation. J Cell Biol 103, 2787, 1986 
11. Whaw BA, Mallis IA, Melincoff G, Straus HW, Gold HR, Haber E. Monoelonal antibody to cardiac myosin: imaging of experimental myocardial intarction. Hybridoma 3,11, 1984

12. Lacmmli UK: Cleavage of structural proteins during the alssembly of the head of the bacteriophage T4. Nat ture $227,680,1970$

13. Towbin $\mathrm{H}_{*}$ Stuehelin $\mathrm{Th}$, Gordon J: Electrophoretic transfer of proteins from polyacrylamide gets to riturocllulose sheets: procedure and soms applications. Biochem $76,4350,1979$

1.4. Schrier PI, Bernards R, Vaessen RTMJ, Howweling A, van der Eb AJ: Expression of class I major histocompatibility antigens switched of by highly oncogenic adenovirus 12 in transformed rat cells. Nature 305,771 , 1983

15. Phlajanienti $T$, Tryggyason K, Myers JC, Kurkinen M, Lebo R, Chüng M, Prockop DJ: cDNA clones coding for the pro a] IV chain of human procolagen reveal an unusual homology of amino acid sequences in wo halves of the carboxyl-terminat domain. $J$ Biol Chem 260,7681, 1985

16. Feinborg AP, Vogelstein B: A lechnique for radiolabeling DNA restriction endonuclease fragments to high spacific aclivity. Anal Biochem 132, 6, 1983

17. Feinberg AP, Vogelstem B: Adendum: A lechnique for radiolabeling DNA restriction endonuclease fragments to high specific activity. Anal Biochem 137, 266, 1984

18. Miller EJ, Rhodes KR: Preparation and characterization of the different types of collagen. Methods in Enzymol $82,32,1982$

19. Whitehead RH, Brown A, Bhathal PS: A method for the isolation and culture of human colonic crypts in collagen gels. In Vitro Cellular \& Developmental Biology 23,436, 1987

20. Biell E, Ivarsson B. Merrill Ch: Production of a tissue-like structure by contraction of collagen lattices by humany fibroblasts of different proliferatiwe potential in vitro. Cell Biol 76, 1274, 1979

21. Nusgens $\mathrm{B}$, Merrill $\mathrm{Ch}$, Lapiere $\mathrm{Ch}$, Bell $\mathrm{E}$ : Collagen biosynthesis by cells in a tissue equivalent matrix in witro. Collagen Rel Res 4, 351, 1984 


\section{Summary}

This thesis focusses on aspects of the heterogeneity of basement membranes (BM). Chapter 1 provides a brief introduction on the structure and composition of normal and pathological BM. The BM components which occur in almost all BM are briefly described as well as the components with a more limited tissue distribution. Furthermore the aim of the studies described in this thesis is outlined.

In chapter 2 the development of BM reactive monoclonal antibodies (MA), by immunization of mice with intact denuded BM is described. MA 1052 and 1053 reacted with the BM of the epidermis and epidermal adnexa and furthermore in the lung with the BM of the alveolar epithelium. In the gastrointestinal tract only the superficial part of the epithelial BM reacted. MA 1065 showed immunoreactivity with the epidermal and adnexal BM in the skin and the epithelial BM of trachea and oesophagus, and futhermore showed pericellular staining of the basal keratinocytes and basal corneal epithelial cells. MA 1087, raised against human glomerular BM, showed immunoreactivity with all $B M$, except the central epithelial BM in the cornea. Furthermore the susceptibility of the target epitopes of these MA for various enzymes, and the localization of the epitopes in the different layers of the BM was tested, the latter by chemical splitting of human skin. The results indicate that the epitopes of MA 1052, 1053, 1065 and 1087 are susceptible for proteases, but not degraded by bacterial collagenase.

In chapter 3 the epitopes of MA 1052, 1053 and 1087 are characterized. Despite the differences observed by immunohistochemical evaluation of the tissue distribution patterns of these antibodies described in chapter 2 , all three antibodies reacted with the same bands on western blots of isolated and collagenase digested glomerular and amniotic BM. Comparing the molecular weight of these bands with the stained bands on immunoblots of sera from patients with anti-glomerular BM autoantibodies, directed against the NC1 domain of type IV collagen, identical patterns of immunoreactivity were found. From these findings we conclude that all three monoclonal antibodies are reactive with epitopes localized in the non-collagenous (NC1) domain of type IV collagen.

An example of $\mathrm{BM}$ heterogeneity in connection with one type of epithelium is described in chapter 4 . We found that central human epithelial corneal BM lacks immunoreactivity for type IV collagen, using various anti-type IV collagen antibodies. In similar experiments laminin was found uniformly distributed in the entire corneall epithelial BM. By electronmicroscopy the central corneal region did not show a characteristic epithelial BM. Several explanations are considered for the apparent lack of type IV collagen immunoreactivily: 1. Type IV collagen is totally absent and a different structural component is deposited or Bowman's membrane takes over type IV collagen function; 2 . Type IV collagen determinants are masked by glycoproteins or proteoglycans; 3 . The arrangement of BM components in a supramolecular structure is altered resulting in loss of type IV collagen determinants. If type IV collagen is indeed absent this could be due to the high level of differentiation of central corneal epithelium, which is generated in the limbal proliferation 
zone, assuming that highly differentiated epithelium can not produce a BM. Alternatively, the acellular Bowman's membrane might lack triggers to induce its production by the epithelial cells. It is concluded that central human comeal epithelial BM is the only BM which lacks immunoreactivity with antibodies to type IV collagen, and therefore the basic structure of this BM might be different from that of other BM.

In chapter 5 we describe the isolation and cultivation of umbilical cord stromal cells. The stromal cell by immunohistochemistry appears to combine characteristics of muscle cells, in containing desmin, smooth muscle actin and myosin and being enveloped by BM components, and of fibroblasts, in being reactive with fibronectin. Ultrastructurally, these cells have the same characteristics as myofibroblasts in granulation tissue or in healing wounds. They contain fibroblast-like endoplasmic reticulum, peripheral parallel cytoplasmatic filaments with dense body condensations and discontinuous extracellular BM-like material. Therefore, we conclude that the stromal cells of the umbilical cord stroma are myofibroblasts. Myofibroblasts appear to be the only cell type which produce ample amounts of BM material which is not deposited into a continuous BM.

In chapter 6 experiments are described with human colonic tumor cell lines (5583-E, HT29), which do not produce immunoreactive BM type IV collagen in vitro. These cells were xenografted into nude rats to generate epithelial neoplasms. By immunohistochemistry, no human but only rat type IV collagen containing BM were observed at the transition of tumor cells and host stroma. Two other tumor cell lines (WISH, KB), showed BM structures in vivo which stained both with human and host specific anti-type IV collagen antibodies. These findings were in agreement with results of in situ hybridization experiments using a type IV collagen c-DNA probe. In the xenografts of 5583-E and HT-29, hybridization was observed exclusively with the rat mesenchyme between the tumor cells, whereas xenografts of WISH and KB showed a hybridization reaction with the tumor cells and rat stromal components. Furthermore in rat epidermis hybridization was observed with basal keratinocytes and with the stroma adjacent to the epithelial BM. From these results we conclude that in xenografts of human cancer cells but also in normal epithelia, stromal cells contribule to the deposition of a BM.

In chapter 7 experiments are described which attempted to screen human normal and tumor cells in their capability to produce BM components in vitro. Cells were grown on gelatin coated glass slides or on denuded amniotic BM or cytocentrifuged on glass slides and stained with antibodies to BM components. Culture supernatants were precipitated and subsecutently electrophoresed and immunoblotted using antibodies to BM components. Cytoplasmic type IV collagen mRNA was determined by Northern blotting. Furthermore, the role of artificial extracellular matrix was investigated in its ability to influence the production of BM components in vitro. Only a few cell lines (KB, WISH and myofibroblasts) were still capable to produce BM components in vitro.

In chapter 8 , the results of the studies are discussed in a broader context.

Finaly, in chapter 9 some of the technicues used in the experiments reported in this thesis are extensively described. 
So far BM research has primarily focussed on the components which cam be observed in nearly all BM. Our experiments show that the macromolecular structure of the BM and even the molecular structure of individual BM components may vary depending on the cell or tissue type.

We furthermore show that, in contrast to the generally accepted concept that "epithelial" BM are produced by epithelial cells, mesenchymal cells do contribute to the production and deposition of BM components at the boundary of epithelium and underlying stroma, which lead to the formation of the epithelial/mesenchymal BM. 



\section{Samenvatting}

In dit proefschrift worden enkele aspecten van basale membraan heterogeniteit ( $B M$ ) belicht.

In hoofdstuk 1 wordt de structuur en samenstelling wan de normale en pathologisch afwijkende BM beschrewen. De BM componenten worden ingedeeld in bestanddelen die in alle BM worden waargenomen en componenten die een gelimiteerde BM distributie hebben. In het laatste gedeelte van dit hoofdstuk wordt de vraagstelling van dit proefschrift geschetst.

In hoofdstuk 2 wordt de ontwikkeling van monoclonale antilichamen (MA) beschreven, door muizen te immuniseren met intacte BM. MA 1052 en 1053 reageren met de BM van huid, talg- en zweetklieren en haarschachten van de huid en verder in de long met de BM van het alveolaire epitheel. In de maag-darm tractus reageren deze monoclonalen alleen met de BM aan de top van de villi of crypten. MA 1065, daarentegen, reageert alleen met de $B M$ van de huid, klieren en haarschachten van de huid en met de epitheliale BM van slokdarm en luchtpijp. Verder reageert MA 1065 ook pericellulair met basale huidcellen en basale cornea epitheelcellen. MA 1087, opgewekt door immunisatie met glomerulaire $B M$, reageert met alle $B M$, met uitzondering van de centrale epitheliale $B M$ in de cornea. Vervolgens wordt de gevoeligheid van de epitopen wan deze MA voor verschillende enzymen beschreven. De epitopen van MA 1052, 1053 en 1065 zijn gevoelig voor proteases, maar blijven intact na collagenase-digestie. De localisatie van de epitopen in de verschillende lagen van de BM, gebeurde na chemische splitsing in de BM. Stukjes humane huid worden geïncubeerd met een zoutoplossing, waarna de opperhuid wan de lederhuid kan worden gescheiden, waarbij de splitsing plaats vindt binnen de BM. De verschillende lagen worden afzonderlijk aangekleurd met de MA. De epitopen van MA 1052 en 1053 komen voor in het gedeelte van de BM dat na splitsing vastzit aan het stromale deel van de huid. Het epitoop van MA 1065 wordt gelocaliseerd in het BM-gedeelte, dat na splitsing direct tegen de epitheel cellen aanzit. Bovendien wordt dit epitoop waargenomen rondom de basale epitheel cellen.

In hoofdstuk 3 worden de epitopen van MA 1052, 1053 en 1087 nader gekarakteriseerd. In tegenstelling tot de verschillen die qua aankleuringspatroon tussen deze MA wordt waargenomen (hoofdstuk. 2), reageren deze drie antilichamen met dezelfde eiwitbanden op western blots, van collagenase gedigesteerde glomerulaire en amnion BM. Identieke aankleuringspatronen worden waargenomen, wanneer de molecuul gewichten van deze banden op western blot worden vergeleken met de aankleuringspatronen van sera van patienten met anti-glomerulaire BM autoantilichamen, gericht tegen het $\mathrm{NCl}$ domein vath type IV collageen. Uit deze bevindingen kunnen we concluderen dat de MA 1052, $1053 \mathrm{en}$ 1087 gericht zijn tegen epitopen die zich binnen het NC1-domein van type IV collageen bevinden. De moleculaire structuur van dit NC1-domein verschilt afhankelijk van weefsel of cel type. 
Een voorbeeld van BM heterogeniteit binnen éc type epitheel wordt beschreven in hoofdstuk 4. De epitheliale BM van het centrale deel van de comea bevat geen type IV collageen, terwijl andere BM componenten, zoals laminine en heparan sulfaat proteoglycaan, over de totale lengte van de comea wordt waargenomen. Ultrastructureel wordt in het centrale gedeelte van de cornea geen normale continue epitheliale BM waargenomen. Mogelijke verklaringen voor de afwezigheid van type IV collageen immunoreactiviteit kunnen zijn:

1. Type IV collageen is totaal afwezig terwijl een andere structurele component of de membraan van Bowman deze structurele functie van type IV collageen overneemt.

2. Type IV collageen epitopen worden gemaskeerd door andere BM componenten zoals glycoproteinnes of proteoglycanen.

3. De supramoleculaire structuur van BM componenten is veranderd waardoor de type IV collageen epitopen verloren gaan. De afwezigheid van type IV collageen kan worden verklaard door de hogere cifferentiatie graad van het centrale cornea epitheel to.v. het epitheel in het perifere gedeelte. Hoger gedifferentieerde cellen zijn magelijk niet meer in staat type IV collageen te produceren. Een andere mogelijkheid is, dat de acellulaire en avasculaire membraan van Bowman bepaalde prikkels mist, die nodig zijn voor het epitheel om type IV collageen te produceren.

Concluderend kunnen we stellen dat de centrale cornea epitheliale BM de enige BM is die type IV collageen mist. De basale structuur van deze BM is waarschijnlijk verschillend van andere $\mathrm{BM}$.

In hoofdstuk 5 wordt de isolatie en het kweken van navelstreng stroma cellen beschreven, Deze stroma cel bevat immunohistochemische karakteristieken zowel van gladde spiercellen (desmine, glad spierweefsel actine, myosine), als van fibroblasten (fibronectine). Ultrastructureel bevatten deze cellen dezelfde karakteristieken als myofibroblasten, die o.a. voorkomen bij de wondgenezing. Deze cellen bevatten een fibroblast-achtig gedilateerd endoplasmatisch reticulum, perifere parallelle cytoplasmatische filamenten met focale condensaties, en discontinuë extracellulaire BM deposities. Deze bevindingen suggereren dat de stromale cellen van de naveistreng myofibroblasten zijn. De myofibroblast is het enige cel type dat behoorlijke hoeveelheden BM componenten maakt, mar deze niet in een continue BM structuur afzetten.

In hoofdlstuk 6 worden experimenten beschreven met humane colon tumor cellijnen (5583-E, HT-29), die geen type IV collageen maken in vitro. Deze cellen werden ingespoten in naakte ratten om epitheliale tumoren te genereren. Met behulp van immunohistochemie wordt geen humane-, maar alleen een ratte-type IV collageen bevattende BM wargenomen bij de overgang van humane tumor cellen en het omliggende gastheer (ratte) stroma. Twee andere tumor cellijnen (WISH, KB), gaven in naakte ratten BM structuren te zien die zowel met humaan als met gastheèr specifieke anti-type IV collageen antilichamen reageren. Deze bevindingen zijn in overeenstemming met de resultaten van in situ hybridisatie experimenten waarbij gebruik werd ge maakt van een type IV collageen cDNA probe. In de xenografts van 5583 en HT-29 werd alleen hybridisatie waargenomen met cellen in het rattestroma, terwijl xenografts van WISH en 
$\mathrm{KB}$, zowel met de tumorcellen als met de cellen in het rattestroma hybridisatie te zien gaven. Verder werd in ratte-epidermis hybridisatie waargenomen zowel in de basale keratinocyten als in stroma cellen aangrenzend aan de epitheliale BM. Uit deze resultaten kan worden geconcludeerd dat in xenografts van humane tumorcellen, maar ook in normale epithelia, stromale cellen een rol spelen bij de depositie van de BM.

In hoofdstuk 7 worden experimenten beschreven waarin wordt getracht de productie van BM componenten in vitro te screenen. Cellen werden gekweekt op gelatine gecoate object-glaasjes, op gedenudeerde amnion BM of gecentrifugeerd op glaasjes en vervolgens. aangekleurd met de anti-BM antilichamen. Supernatant van deze celkweken werd geprecipiteerd en vervolgens geëlectroforeerd en geblot naar nitrocellulose papier en aangekleurd met de antilichamen gericht tegen BM componenten. Cytoplasmatisch type IV collageen mRNA werd bepaald d.m.v. northern blotting. Verder werd de rol van een artificiële extracellulaire matrix getest op de beïnwloeding van de productie van BM componenten in vitro. Slechts een aantal van de geteste tumor cellijnen (WISH, KB, myofibroblasten) waren in vitro nog in staat om BM componenten te produceren.

In hoofdstuk 8 worden de resultaten van deze studies belicht tegen een bredere achtergrond. Tevens worden enkele suggesties voor verder onderzoek in de nabije toekomst besproken.

Ten slotte worden in hoofdstuk 9 enkele technieken uitgebreider beschreven.

Tot dusverre is veel onderzoek verricht aan componenten die in alle BM voorkomen. In dit proefschrift wordt echter beschreven, dat de macromoleculaire samenstelling en zelfs de moleculaire structuur van afzonderlijke componenten kunnen verschillen, afhankelijk van het weefsel of de cel waarin deze bestanddelen voorkomen.

In dit onderzoek wordt tevens beschreven, dat in tegenstelling tot de algemeen geaccepteerde opvatting, namelijk, dat de epitheliale BM enkel worden geproduceerd door de aangrenzende epitheelcellen, óók de stromale/mesenchymale cellen een bijdrage leveren bij de tot stand koming van de "epitheliale-mesenchymale" BM. 



\section{Dankwoord}

Het onderzoek beschreven in dit proefschrift werd uitgevoerd binnen het kader van het KWF-project "Basement membranes in cancer" (project nr. RUL 85-2).

Op de eerste plaats ben ik mijn promotor Prof. dr. F.T. Bosman zeer erkentelijk. Beste Fré, bedankt voor de kans die je mij hebt gegeven om na mijn stage-periode en mijn militaire diensttijd te beginnen met dit promotieonderzoek. Zonder jouw stimulerende begeleiding en goede suggesties had dit proefschrift nooit de huidige vorm bereikt.

Dr. M.G. Havenith, beste Miek, ik bedank je voor de prettige samenwerking die we tijdens dit onderzoek hebben gehad. Jouw nieuwe ideeën en pathologische kennis hebben me zeer geholpen dit proefschrift te completeren.

Het experimentele werk van Monique Vallinga-Ummelen en Cor Beek verdient al mijn waardering, zonder hen zou het schrijven van dit proefschrift niet mogelijk zijn geweest. Cor, tevens bedankt voor het wegwijs maken in het automatiseringsland. Hierdoor ben ik in staat geweest de tot stand koming van het proefschrift geheel in eigen hand te houden. Dr. J. Ten Kate ben ik erkentelijk voor zijn bijdrage aan het moleculaire biologische deel van dit onderzoek en voor zijn interesse en goede suggesties met betrekking tot het experimentele werk.

Edith van de Linden, Judith Stouten en Piet op de Beek dank ik yoor hun werkzaamheden die ten goede zijn gekomen aan de tot stand koming van dit proefschrift

Een woord wan dank gaat uit naar: de afdeling verloskunde voor hun coopperativiteit; de centrale proefdiervoorziening, voor de goede verzorging van de dieren; Prof.dr. J. Veerkamp en Drs. B. van den Heuvel (Afdeling Biochemie te Nijmegen) voor het beschikbaar stellen van glomerulaire basale membraan extracten.

Prof. dr. P.J.C. van Breda Vriesman wil ik danken voor de beschikbaar stelling van de patientensera en voor zijn voorzitterschap van de beoordelingscommissie. Ook de andere leden van deze commissie, Prof. dr. Ph. J. Hoedemaeker, Prof. dr. J. Drukker, Prof. dr. J.P.M. Geraedts en Prof. dr. I. Damjanov wil ik danken voor de kritische kanttekeningen en suggesties, die hebben geleid tot inhoudelijke verbetering van dit proefschrift.

Tevens wil ik allen, die niet met naam vermeld zijn in dit proefschrift, maar wel cen bijdrage hieraan geleverd hebben, van harte bedanken.

Tot slot wil ik mijn vrouw, Caroline, hartelijk bedanken voor cie steun die zij mij tijdens de afgelopen periode heeft gegeven. 



\section{CURRICULUM VITAE}

J.P.M. Cleutjens werd op 18 juni 1958 geboren in Oirsbeek. In 1977, na het behalen van het eindexamen Atheneum B aan het Sint Jans-college te Hoensbroek, begon hịj zijn studie biologie aan de Landbouwhogeschool (nu Landbouwuniversiteit) te Wageningen. Op 10 juli 1981 werd het candidaatsexamen biologie behald. Gedurende de studie heeft hij meerdere malen studenten begeleid tijdens de dierkunde practica voor eerste en tweede jaars biologie en $\mathrm{N}-20$ studenten. Tijdens de studie werd hij opgeroepen onder " $\mathrm{s}$ lands wapenrok. Zijn militaire loopbaan startte op 7 maart 1984. Hij werd geplaatst als toegevoegd S2, bij de staf van de $13^{\mathrm{e}}$ Pantserbrigade te Oirschot. Vanaf 5 juni 1985 werd hem buitengewoon verlof buiten bezwaar rijksschatkist verleend. Op 28 mei 1985 werd het doctoraal examen in de landbouwwetenschappen studierichting biologie behald met als hoofdwakken celbiologie en dierfysiologie en als bijvak toxicologie. Op 1 juni 1985 werd een begin gemaakt met een promotieonderzoek aan de vakgroep Pathologie aan de Rijksuniversiteit Limburg, getiteld: "Basement membranes in cancer". Dit onderzoek werd mogelijk gemaakt door de financiële steun van het Koningin Wilhelmina Fonds (RUL. 85-2). 